\title{
Alterations in hepatic enzyme activity and progesterone clearance in lactating dairy cows
}

\author{
Caleb Owens Lemley \\ West Virginia University
}

Follow this and additional works at: https://researchrepository.wvu.edu/etd

\section{Recommended Citation}

Lemley, Caleb Owens, "Alterations in hepatic enzyme activity and progesterone clearance in lactating dairy cows" (2010). Graduate Theses, Dissertations, and Problem Reports. 3085.

https://researchrepository.wvu.edu/etd/3085

This Dissertation is protected by copyright and/or related rights. It has been brought to you by the The Research Repository @ WVU with permission from the rights-holder(s). You are free to use this Dissertation in any way that is permitted by the copyright and related rights legislation that applies to your use. For other uses you must obtain permission from the rights-holder(s) directly, unless additional rights are indicated by a Creative Commons license in the record and/ or on the work itself. This Dissertation has been accepted for inclusion in WVU Graduate Theses, Dissertations, and Problem Reports collection by an authorized administrator of The Research Repository @ WVU.

For more information, please contact researchrepository@mail.wvu.edu. 


\title{
Alterations in Hepatic Enzyme Activity and Progesterone Clearance in Lactating Dairy Cows
}

\author{
Caleb Owens Lemley
}

Dissertation submitted to the Davis College of Agriculture, Natural Resources and Design at West Virginia University in partial fulfillment of the requirements for the degree of

\author{
Doctor of Philosophy \\ in \\ Reproductive Physiology \\ Matthew E. Wilson, Ph.D., Chair \\ Kenneth P. Blemings, Ph.D. \\ K. Marie Krause, Ph.D. \\ Kimberly M. Barnes, Ph.D. \\ Kimberly A. Vonnahme, Ph.D.
}

Division of Animal and Nutritional Sciences

Morgantown, West Virginia

2010

Keywords: Progesterone Clearance, Insulin, Cytochrome P450, Aldo-keto Reductase 


\title{
ABSTRACT \\ Alterations in Hepatic Enzyme Activity and Progesterone Clearance in Lactating Dairy Cows
}

\author{
Caleb Owens Lemley
}

In the cow, inadequate concentrations of progesterone during gestation may lead to an abrupt termination of pregnancy. The primary organ involved in progesterone catabolism is the liver, which contains an abundance of cytochrome P450 isozymes (CYP; EC 1.14.14.1) and aldo-keto reductases (AKR; EC 1.1.1.145-151), which are involved in the first phase of steroid inactivation, before second phase conjugation and excretion of the steroid metabolite by UDP-glucuronosyltransferases (UGT; EC 2.4.1.17). The objectives of the current experiments were to: 1.) determine the effect of feeding two isoenergetic and isonitrogenous diets formulated to cause divergent insulin secretion, on hepatic progesterone catabolic enzyme activity (CYP2C, CYP3A and AKR1C), as well as progesterone clearance, and 2.) determine the relative contributions of CYP2C, CYP3A, AKR1C and UGT enzymes to total progesterone decay in primary bovine hepatic cell cultures. In the first set of experiments, Holstein cows were randomly assigned to either a high cornstarch or a high fiber diet in a cross-over experimental design consisting of two $14 \mathrm{~d}$ periods at the WVU animal sciences farm $(\mathrm{n}=22)$ or the NDSU dairy research barn $(\mathrm{n}=11)$. Dry matter intake and milk yield were similar between the two diets. Energy balance was improved in cows consuming the high cornstarch diet. Insulin concentrations were elevated in cows consuming the high cornstarch diet versus the high fiber diet. Both CYP2C and CYP3A activity were decreased in cows consuming the high cornstarch diet, while AKR1C tended to be lower in NDSU cows fed the high cornstarch diet. The half-life of progesterone was longer in cows fed the high cornstarch diet versus the high fiber diet. In NDSU cows, liver blood flow was similar between the two diets $(1891 \pm 91 \mathrm{l} / \mathrm{h})$, while the metabolic clearance rate of progesterone tended to be lower in cows fed the high cornstarch diet $\left(25 \pm 51 / \mathrm{h}^{*} \mathrm{BW}^{0.75}\right)$ versus the high fiber diet $(40 \pm 6$ $\left.1 / \mathrm{h}^{*} \mathrm{BW}^{0.75}\right)$. In the second experiment, the contribution of CYP2C and CYP3A enzymes to progesterone inactivation in bovine hepatic cell cultures was $40 \%$ and $15 \%$, respectively. Depending on the inhibitor used, it would appear that the aldo-keto reductase enzymes contribute $\sim 40 \%$ to the observed progesterone decay; although, a portion of this inactivation may be due to the loss of UGT activity. In summary, cows consuming the high cornstarch diet had elevated insulin concentrations, lower hepatic progesterone catabolic enzyme activity and lower progesterone clearance compared to cows consuming the high fiber diet. The majority of progesterone inactivation occurs via hepatic CYP2C, CYP3A and AKR1C activity and inhibiting these enzymes will increase the bioavailability of progesterone. Therefore, feeding diets that stimulate insulin secretion could alter progesterone clearance during lactation by decreasing hepatic progesterone catabolic enzyme activity. This dietary relationship could be used to increase progesterone bioavailability in dairy cows that have increased progesterone clearance due to high-energy demands and elevated dry matter intake. 


\section{TABLE OF CONTENTS}

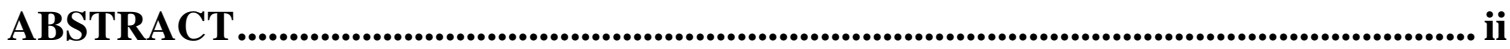

TABLE OF CONTENTS .................................................................................................. iii

LIST OF FIGURES …….............................................................................................................v

LIST OF TABLES

ACKNOWLEDGEMENTS ............................................................................................... viii

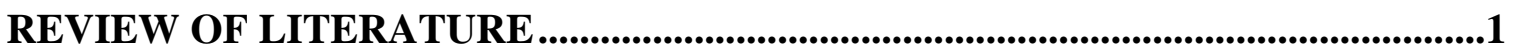

Progesterone and Maintenance of Pregnancy ............................................................... 1

Progesterone Biosynthesis................................................................................................. 3

Metabolic Clearance of Progesterone ................................................................................. 5

Hepatic Catabolic Enzymes and Steroid Biotransformation......................................... 8

Nutrition, Energy Balance and Reproductive Performance...................................... 12

STATEMENT OF THE PROBLEM ...................................................................................17

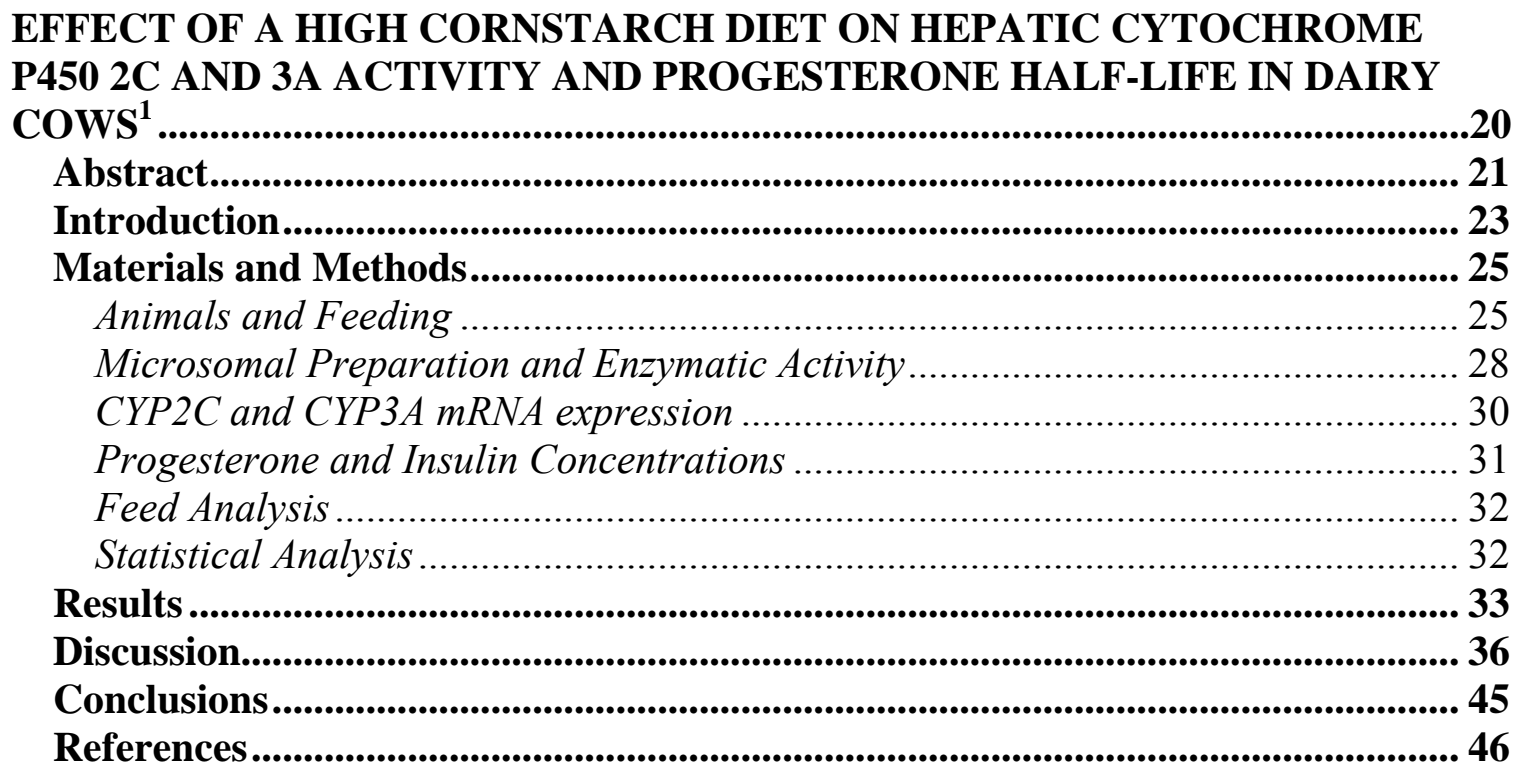

DIET-INDUCED ALTERATIONS IN HEPATIC PROGESTERONE CATABOLIC ENZYME ACTIVITY AND PROGESTERONE CLEARANCE RATE IN LACTATING DAIRY COWS ..............................................................51

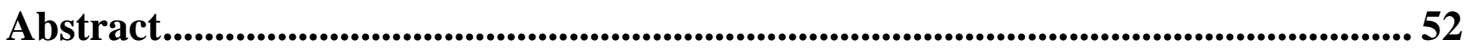

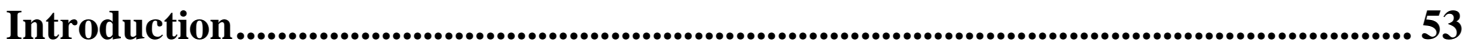

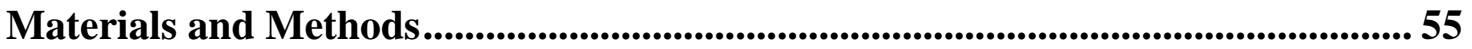

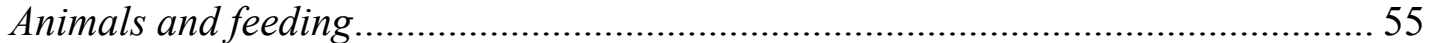

Liver blood flow, MCR of progesterone and insulin concentrations....................... 59 


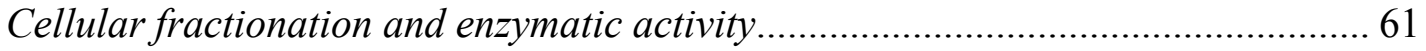

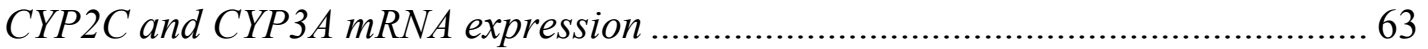

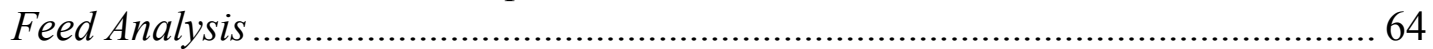

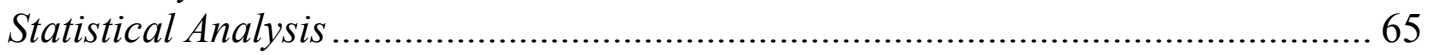

Results ............................................................................................................6 65

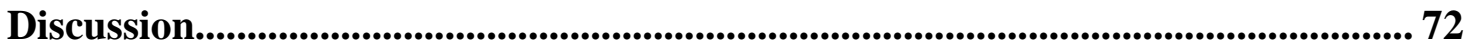

References ...................................................................................................................... 78

\section{EFFECT OF CYTOCHROME P450 AND ALDO-KETO REDUCTASE INHIBITORS ON PROGESTERONE DECAY IN PRIMARY BOVINE HEPATIC CELL CULTURES ${ }^{1}$..................................................................................8}

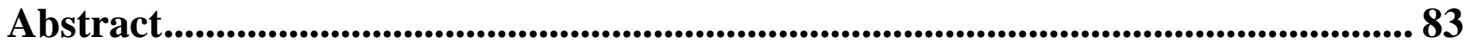

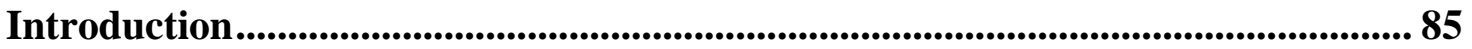

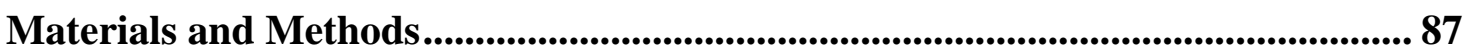

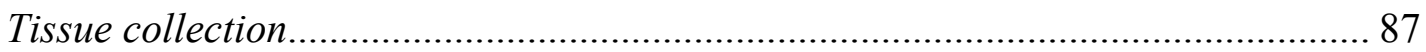

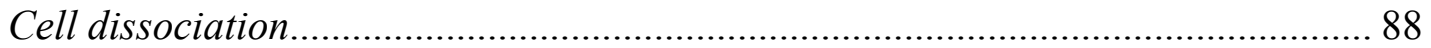

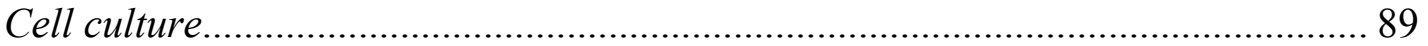

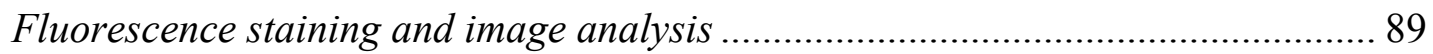

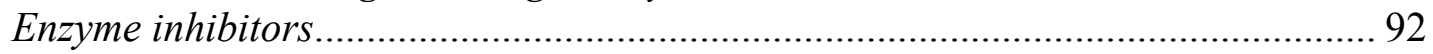

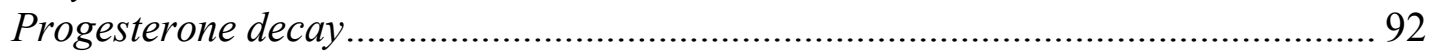

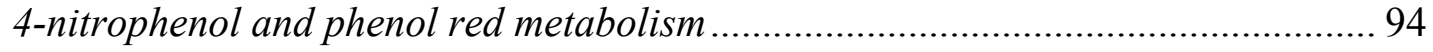

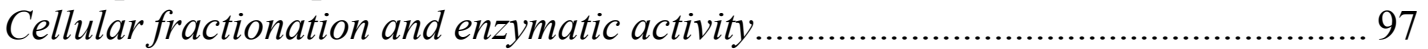

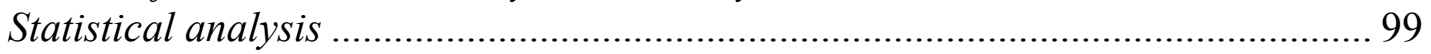

Results ................................................................................................................................ 99

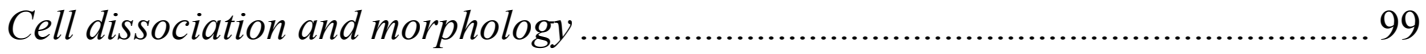

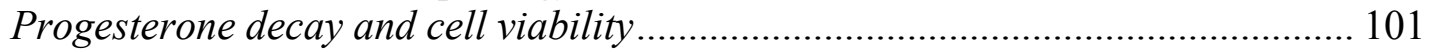

Metabolism of 4-nitrophenol and phenol red in intact cells ................................... 104

Aldo-keto reductase and cytochrome P450 activity in cellular fractions ................ 104

Discussion..................................................................................................... 107

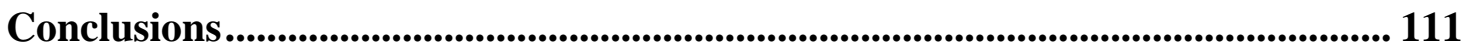

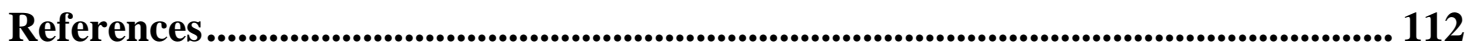

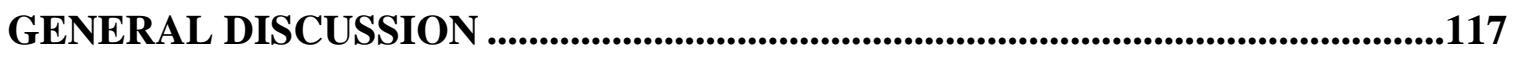

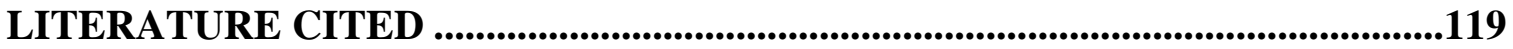




\section{LIST OF FIGURES}

Figure 1. The cross-over experimental design consisted of two $14 \mathrm{~d}$ periods. Cows were acclimated to their new diets during the first $10 \mathrm{~d}$ of the experiment. Samples were collected on d 11, 12, 13 and 14. On d 14 plasma insulin (closed triangles) concentrations were determined at $0,1,2,3,4,5,6,8,10$ h postfeeding and plasma progesterone ( $\mathrm{P} 4$; open circles) concentrations were determined after CIDR removal at 3, 3.5, 4, 5 and $6 \mathrm{~h}$ post-feeding.

Figure 2. Insulin area under the curve (AUC; left two bars) and average insulin concentrations (right two bars) at the time of liver biopsy $(3.16 \pm 0.04 \mathrm{~h}$ postfeeding) in cows consuming a high cornstarch diet (open bars) or a high fiber diet (closed bars). Asterisk indicates $P<0.005$.

Figure 3. Hepatic CYP2C (left two bars) and CYP3A (right two bars) activity for cows consuming a high cornstarch diet (open bars) or a high fiber diet (closed bars). Asterisk indicates $P<0.05$ and double dagger indicates $P=0.09$.

Figure 4. Fractional rate constant of progesterone decay (k; left two bars) and average half-life of progesterone ( $\mathrm{T}_{1 / 2}$; right two bars) in cows consuming a high cornstarch diet (open bars) or a high fiber diet (closed bars). The equation $\mathrm{T}_{1 / 2}=$ $\ln (2) / \mathrm{k}$ was used to calculate the half-life of progesterone. Double dagger indicates $P=0.08$.

Figure 5. The crossover experimental design consisted of two identical 14 day periods that ran consecutively to one another. On day 11 cows were infused with BSP to estimate liver blood flow at hours 1, 2, 3 and 4 post-feeding. On day 12 cows were injected with Lutalyse before the $1600 \mathrm{~h}$ milking and a liver biopsy was taken $3.77 \pm 0.09$ hours post-feeding. On day 13 plasma samples were taken to determine insulin (closed triangles) and progesterone ( $\mathrm{P} 4$; open circles) concentrations. CIDRs were removed after the start of $\mathrm{P} 4$ infusion, 0 hour postfeeding. MCR of P4 was determined at hours 1, 2, 3 and 4 post-feeding and P4 decay was determined at the end of infusion, hours $4,4.5,5,6,8$ and 10 postfeeding...

Figure 6. Metabolic clearance rate of progesterone, standardized by body weight, for cows consuming the high cornstarch diet (open circles, $\mathrm{n}=10$ ) or the high fiber diet (closed circles, $\mathrm{n}=10$ ). Effect of diet $P=0.06$, double daggers $(\$)$ represent $P<0.10$.

Figure 7. Fractional rate constant of progesterone decay (k; left two bars) and average half-life of progesterone ( $\mathrm{T}_{1 / 2}$; right two bars) in cows consuming a high cornstarch diet (open bars, $\mathrm{n}=10$ ) or a high fiber diet (closed bars, $\mathrm{n}=11$ ). The equation $T_{1 / 2}=\ln (2) / k$ was used to calculate the half-life of progesterone. Asterisk (*) represents a $P<0.01$ 
Figure 8. Immunofluorescence images from dairy cow hepatic cell cultures. Cells were stained for albumin (green, FITC), actin (red, PE) and nuclei (blue, Hoechst). Images (A) and (B) were stained for albumin, actin and nuclei. Image (C) was stained for albumin and actin. Image (D, negative control) was incubated with the secondary antibodies conjugated to fluorophore and nuclei were stained with Hoechst. White, yellow and red arrows highlight cell populations that were positive for albumin, actin or neither, respectively.

Figure 9. Progesterone decay (A) in dairy cow hepatic cell cultures after a four hour preincubation with no inhibitor (control), ticlopidine, diltiazem, curcumin, dicumarol and naproxen followed by a one hour challenge with $5 \mathrm{ng} / \mathrm{ml}$ progesterone plus inhibitor. Percent progesterone decay inhibited (B) compared to control cells preincubated with no inhibitor. Data are represented as mean \pm SEM, and different letters depict treatment differences $(P<0.05)$.

Figure 10. Four-nitrocatechol production (A), 4-nitrocatechol glucuronidation (B) and phenol red glucuronidation $(C)$ in dairy cow hepatic cell cultures after a four hour preincubation with no inhibitor (control), ticlopidine, diltiazem, curcumin, dicumarol and naproxen. Data are represented as mean \pm SEM, and different letters depict treatment differences $(P<0.05)$.

Figure 11. AKR1C (A), CYP2C (B) and CYP3A (C) activity after a 30 minute challenge with no inhibitor (control), ticlopidine, diltiazem, curcumin, dicumarol and naproxen. Values are expressed as pmol of NADP reduced per min per mg of cytosolic protein (AKR1C) or pmol of NADPH oxidized per min per mg of microsomal protein (CYP2C, CYP3A). Asterisk (*) represents a significant difference $(P<0.05)$ from controls. Cross $(\dagger)$ represents a significant difference $(P<0.05)$ within treatment due to inhibitor concentration $(1 \mathrm{x}$ or $3 \mathrm{x}$ inhibitor concentration compared to cell culture experiments). 


\section{LIST OF TABLES}

Table 1. Experimental diet composition and average ( \pm SEM) nutrient composition from all three replicates.

Table 2. Effect of a high cornstarch versus a high fiber diet on DMI, milk production and energy balance.

Table 3. Pearson correlation coefficients (r) for energy balance (EB), dry matter intake (DMI), milk yield (MY), insulin concentrations (Insulin), progesterone half-life (Half-life), CYP2C activity (2C Act), CYP3A activity (3A Act), CYP2C mRNA expression (2C mRNA) and CYP3A mRNA expression (3A mRNA) ${ }^{1}$.

Table 4. Experimental diet composition and average ( \pm SEM) nutrient composition for high cornstarch $(n=4)$ or high fiber diet $(n=4)$.

Table 5. Effect of a high cornstarch diet $(n=11)$ versus a high fiber diet $(n=11)$ on intake and milk production in lactating dairy cows.

Table 6. Average insulin concentrations over the $10 \mathrm{~h}$ blood sampling period, insulin concentrations at the time of liver biopsy $(3.77 \pm 0.09 \mathrm{~h}$ post-feeding) and hepatic CYP2C, CYP3A and AKR1C activity in cows consuming a high cornstarch diet $(n=11)$ or a high fiber $\operatorname{diet}(n=11)$.

Table 7. Correlation coefficients $(r)$ for energy balance $(E B, n=22)$, average insulin concentrations over the $10 \mathrm{~h}$ sampling period (Insulin, $\mathrm{n}=22$ ), average liver blood flow (LBF, $n=21$ ), progesterone half-life (Half-life, $n=21$ ), average metabolic clearance rate of progesterone on a body weight basis (MCR, $n=20$ ), CYP2C activity (2C Act, $\mathrm{n}=22$ ), CYP3A activity (3A Act, $\mathrm{n}=22$ ), AKR1C activity $($ AKR Act, $\mathrm{n}=22)$. $P$-values are presented in parentheses.

Table 8. Liver biopsies from six lactating dairy cows used for cell culture experiments. Stage of lactation, milk yield and liver biopsy weight for individual dairy cows, and cell yield and viability following tissue dissociation using a nonperfusion technique.

Table 9. Enzyme inhibitors, phase I or phase II of steroid biotransformation, used for intact cell culture and fractionated tissue experiments

Table 10. Substrates used for enzymatic activity assays in intact cell cultures or fractionated tissue preparations.

Table 11. Percentage progesterone decay inhibited in a preliminary experiment. Progesterone decay was determined in duplicate in hepatic cultures from 2 pigs (n $=4)$ and 2 dairy cows $(n=4)$. 


\section{ACKNOWLEDGEMENTS}

I would like to acknowledge my committee members for all of their help and guidance throughout my graduate career. My advisor, Dr. Wilson has been an integral part to my graduate education including presentation and writing skills as well as research and teaching experience. I would like to thank Dr. Blemings for all of his guidance on the enzyme activity assays and for holding a student research presentation meeting each semester to disseminate recent findings and to discuss potential research problems. I was grateful to receive input from both Dr. Blemings and Dr. Barnes during these research presentations over the past few semesters. I appreciate all of Dr. Krause's input with dairy cattle nutrition and for designing the experimental diets for the following in vivo studies. In addition, I would like to thank Dr. Vonnahme for providing us the opportunity to travel to NDSU to study progesterone clearance in a tie stall setting. Several students from both WVU and NDSU assisted with the following experiments. I would like to give a special thanks to Tiffany Wilmoth and Lisa Tager for taking time away from their studies to assist with the WVU feeding experiments. I would also like to thank Lisa for analyzing feed samples in both the WVU and NDSU experiemental diets. Tiffany, Lisa and several other students have provided me with valuable discussions focusing on all aspects of animal science and I am grateful for their intellectual input over the past few years. I would also like to thank the employees of the WVU Animal Science Farm and NDSU Dairy Research and Teaching Center for all of their help with the feeding experiments. I am grateful to have a very supportive family and I would like to acknowledge my parents, Buddy and Jeannie Lemley, for their motivation and interests in my future endeavors. 


\section{REVIEW OF LITERATURE}

\section{Progesterone and Maintenance of Pregnancy}

Progesterone is needed to maintain a successful pregnancy and removal of the corpus luteum, or progesterone source, will lead to termination of pregnancy unless exogenous progesterone is provided (McDonald et al., 1952). Csapo (1956) proposed the "progesterone block hypothesis" while studying pregnancy in the rabbit. This hypothesis states that progesterone maintains pregnancy by directly blocking labor and that removal of progesterone will initiate parturition (Csapo, 1956). Directly proceeding parturition, Garfield et al. (1977) observed increased insertion of gap junctions between myometrial smooth muscle cells. Garfield et al. (1978) found that progesterone supplementation in pregnant ovariectomized rats was needed to prevent the insertion of gap junction proteins between these smooth muscle cells. Gap junctions consist of a hexameric assembly of proteins referred to as connexins. Uterine mRNA for connexin-43 in the rat, sheep and human was found to be elevated near term and peaked during delivery due to a drop in concentrations of progesterone (Orsino et al., 1996).

Progesterone has also been shown to down-regulate uterine contractilityassociated genes (Mesiano, 2007). Tezuka et al. (1995) showed a 6.9 fold increase in rat myometrial mRNA expression of voltage-dependent calcium channels directly before delivery (day 22), which could be blocked by treating with progesterone from day 19 to 22. Hirsbrunner et al. (2002) conducted an in vitro study on spontaneous myometrial contractility, which showed that cows in estrus $(<0.5 \mathrm{ng} / \mathrm{ml}$ progesterone $)$ had an elevated contractility in circular smooth muscle cells of the myometrium compared to 
cows in diestrus ( $>4.0 \mathrm{ng} / \mathrm{ml}$ progesterone). These differences in myometrial excitationcontraction are brought about by the genomic actions of progesterone, which lead to a relaxed and quiescent uterus able to maintain a successful pregnancy until progesterone withdrawal (Mesiano, 2007).

In addition to parturition, progesterone can influence the early uterine environment including endometrial secretion of nutrients and growth factors that are essential for early embryonic development (Graham and Clarke, 1997). Green et al. (2005) observed greater progesterone concentrations 5 days post-insemination in Holstein cows containing embryos beyond the 8-cell stage of development. Moreover, supplementing cows with progesterone from day 5 to 9 post-insemination resulted in a 4fold increase in trophoblast length and 6-fold increase in uterine concentrations of interferon-tau (Mann et al., 2006). Elevated endogenous concentrations of progesterone may advance embryonic development and improve uterine secretions during early gestation. Larson et al. (2007) supplemented progesterone in the form of an intravaginal progesterone-releasing device (CIDR, resulting in an increase of progesterone by $\sim 1$ $\mathrm{ng} / \mathrm{ml}$ ) from day 3.5 to 10 post-insemination, which increased pregnancy rates by $37 \%$ in cows treated with progesterone (48\%) compared to the control group (35\%). In contrast, Villarroel et al. (2004) found no difference on pregnancy outcomes in repeat-breeder Holstein cows treated with a CIDR from day 5 to 19 post-insemination. Stevenson et al. (2007) found a trend for increased conception rates in Holstein cows treated with a CIDR for 7 days beginning between 4 and 9 days post-insemination $(n=711)$ compared with control cows $(\mathrm{n}=708)$; moreover, of the 5 herds tested in this study, CIDR treatment increased conception rates in 2 of the herds and decreased conception rates in 1 of the 
herds. In general, progesterone supplementation with a CIDR remains a controversial management approach because of the variable results in pregnancy outcomes (Robinson et al., 1989; Stevenson and Mee, 1991; Diskin et al., 2006).

Supplementation with progesterone partially masks the high rates of steroid clearance due to very high feed intake during early lactation. Starbuck et al. (2004) found lower pregnancy retention to week 7 of gestation in dairy cows classified during week 5 of gestation as having low concentrations $(0.5$ to $3.76 \mathrm{ng} / \mathrm{ml})$ versus cows classified as having medium concentrations of progesterone (3.78 to $5.98 \mathrm{ng} / \mathrm{ml})$. Moreover, only a small portion of cows that are classified as having low concentrations of progesterone will improve to the status of having medium concentrations of progesterone (3.78 to $5.98 \mathrm{ng} / \mathrm{ml}$ ) after supplementing with a CIDR, which only marginally improves peripheral concentrations of progesterone $(1 \mathrm{ng} / \mathrm{ml})$.

\section{Progesterone Biosynthesis}

Production of progesterone by the corpus luteum is essential in maintaining pregnancy, and any deficiencies in luteal secretion that cause a reduction in progesterone production, can be associated with an abrupt termination of pregnancy (Gorski et al., 1958; Miller et al., 1963). The first step in progesterone biosynthesis is the endocytosis of cholesterol rich lipoproteins into luteal cells (Christenson et al., 2003). Once inside the cell, cholesterol is transported from the outer mitochondrial membrane to the inner mitochondrial membrane via steroidogenic acute regulatory protein (Stocco et al., 2000). Inside the mitochondrion, cholesterol can be converted enzymatically into pregnenolone by cytochrome P450 side chain cleavage (CYP11A1). Pregnenolone will then be 
converted into progesterone via $3 \beta$-hydroxysteroid dehydrogenase, which is located on the smooth endoplasmic reticulum.

Stormshak et al. (1963) estimated that the sheep corpus luteum, having an average progesterone turnover rate of two minutes, produces approximately 15 to $30 \mathrm{mg}$ of progesterone a day. In sheep, the ovarian venous blood contains an average concentration of $1.52,1.82$, and $1.10 \mu \mathrm{g} / \mathrm{ml}$ of progesterone during the early, mid and late luteal phase, while peripheral concentrations are significantly less. Similar studies in cattle by Gomes et al. (1963), estimated ovarian vein concentrations of progesterone to be $6.2 \mu \mathrm{g} / \mathrm{ml}$ while the jugular vein contained only $11.6 \mathrm{ng} / \mathrm{ml}$. During mid luteal phase, the corpus luteum contained 85 to $570 \mu \mathrm{g}$ of progesterone with considerable cow-to-cow variation. In a similar study in cows, Erb et al. (1967) estimated mean progestin concentrations in the ovarian vein as $2.6 \mu \mathrm{g} / \mathrm{ml}$ while jugular venous plasma averaged $26.7 \mathrm{ng} / \mathrm{ml}$. Bridges et al. (2000) determined that $300 \mathrm{mg}$ of progesterone per day would maintain pregnancies in lutectomized beef cows. McDonald et al. (1952) determined that $100 \mathrm{mg}$ of progesterone administered intramuscularly daily was needed to maintain pregnancy in a significant number of lutectomized cattle before gestational day 200 . However, limited research has been done on estimating luteal progesterone production per day in the cycling or pregnant dairy cow. By using a two minute turnover rate of progesterone (calculated by Stormshak et al., 1963) from the corpus luteum, as well as average luteal content of progesterone (calculated by Erb et al., 1967) we could estimate that a cow produces 300 to $500 \mathrm{mg}$ per day depending on reproductive state. 


\section{Metabolic Clearance of Progesterone}

Uterine and embryonic exposure to progesterone has been estimated to be higher than peripheral tissue due to a counter-current exchange system within the utero-ovarian adnexa (Einer-Jenson and Hunter, 2000). Ovarian venous plasma concentrations of progesterone may be two to three orders of magnitude greater than peripheral concentrations, and part of this relationship can be accounted for by dilution with peripheral blood; however, low peripheral concentrations of progesterone may also be due in part to a high rate of progesterone catabolism. Miller and colleagues (1963) reported a half-life of 33.8 minutes for progesterone in cows. Short and Rowell (1962) estimated a half-life of 7.3 minutes at day 115 of gestation in the ewe and 8.1 minutes just prior to lambing. The normal high rate of catabolism may explain why blood draining the ovary has a very high concentration of progesterone, during the mid luteal phase, compared to jugular plasma progesterone concentrations, blood which has already circulated through the liver and gut regions, where the majority of catabolism takes place.

In sheep, Weems et al. (1989) reported progesterone concentrations in the cranial uterine venous plasma to be $5 \mathrm{ng} / \mathrm{ml} 9$ days postestrus compared with $2 \mathrm{ng} / \mathrm{ml}$ in the jugular plasma. This difference in concentration could be normalized after resection of both oviductal veins, causing a drop in uterine venous concentrations of progesterone down to $3 \mathrm{ng} / \mathrm{ml}$ (Weems et al., 1989). Weems and colleagues hypothesized a transfer of progesterone from the uterine drainage to uterine arteries due to a progesterone gradient, leading to higher concentrations of progesterone in the uterus compared to peripheral tissues. Ginther (1974) diagramed the vascular system of the reproductive tract, which indicated a close proximity between the uterine-ovarian drainage and the uterine artery. 
Therefore, a counter-current exchange of progesterone between the utero-ovarian vein and the uterine artery could supply progesterone to the uterus, bypassing peripheral circulation (Einer-Jenson, 2005). However, the contribution of a counter current exchange system in the ovarian adnexa has been estimated to be $0.3-2 \%$ of total steroids (Einer-Jenson and Hunter, 2000). This is in agreement with the subtle differences Weems and colleagues reported in uterine venous and jugular concentrations of progesterone.

Bedford et al. $(1972,1974)$ reported metabolic clearance rates (volume of blood cleared per unit time) of progesterone to be approximately 3.5 to $4.3 \mathrm{l} / \mathrm{min}$ in sheep. Splanchnic clearance of progesterone could account for $30 \%$ of peripherally administered progesterone tracer catabolism, and of the total clearance in these splanchnic organs, 70 90\% of progesterone was cleared by the liver (Bedford et al., 1974). Bedford and colleagues injected progesterone into the jugular vein, which is not the normal route of drainage for endogenously secreted progesterone and may explain why the liver only accounts for $30 \%$ of total progesterone clearance in their studies. Other researchers have reported greater hepatic progesterone clearance by injecting or infusing progesterone into the lower extremities thereby mimicking the normal anatomical entry of progesterone into systemic circulation. Gurpide (1975) estimated a 70\% hepatic extraction of progesterone in pregnant ewes, and Parr et al. (1993) determined that $96 \%$ of the progesterone entering into the liver and gut region was metabolized by these tissues.

Taking into account that the liver is the primary site of progesterone catabolism, several researchers have correlated liver blood flow, through the hepatic portal vein, and the metabolic clearance rate of progesterone. Parr et al. (1993) showed that a $40 \%$ 
increase in liver blood flow in sheep would double the metabolic clearance rate of progesterone. Studies in the dairy cow by Sangsritavong et al. (2002) determined a positive regression between liver blood flow and metabolic clearance rate of progesterone, the relationship was determined to be metabolic clearance rate $=1.38$ (liver blood flow $)+0.10\left(\mathrm{r}^{2}=0.92\right)$. However, these experiments compared half maintenance versus twice maintenance diets, which are not only confounded with dry matter intake, but energy and protein intake as well. In the pig, the metabolic clearance rate of progesterone was not correlated with total cytochrome P450 content in the liver after altering feed intake; however, total cytochrome P450 content was positively correlated with the rate of progesterone inactivation in vitro (Miller et al., 1999). Furthermore, induction of mixed function monooxygenases (cytochrome P450 superfamily) using phenobarbital can alter the rate of steroid clearance in the barrow and gilt (Thomford and Dziuk, 1986).

Several studies have focused on progesterone production during the estrous cycle and various cellular mechanisms and models have been elucidated in controlling luteal function (Niswender et al., 2000; Schams and Berisha, 2004). However, elevated rates of steroid inactivation may contribute to lower concentrations of progesterone in the pregnant lactating dairy cow (Rhinehart et al., 2009). Rhinehart et al. (2009) collected corpora lutea from pregnant ( 28 to 34 ) lactating dairy cows that were divided into low or high progesterone groups. A subcutaneous injection of $150 \mathrm{mg}$ of progesterone was given every $12 \mathrm{~h}$ to maintain pregnancy, and those cows that were previously classified as having high concentrations of progesterone had a greater progesterone area under the curve compared to the low progesterone group post-lutectomy. Gene expression in 
progesterone synthesizing luteal tissue for components of the endothelin and prostaglandin systems were not different between the high and low progesterone groups, which may indicate a greater involvement in steroid clearance, versus steroid production, in regulating peripheral concentrations of progesterone in pregnant lactating dairy cows (Rhinehart et al., 2009). More recently, Turino et al. (2010) determined clearance rates and half-life of progesterone in high producing early lactating $(37.5 \mathrm{~L}$ of milk/day) versus low producing late lactating (19.3 L of milk/day) dairy cows administered a bolus i.v. injection of progesterone $(100 \mathrm{mg})$. The low producing cows had a 2-fold longer half-life of progesterone and a $40 \%$ reduction in progesterone clearance rates compared to the high producing early lactation cows. These results are in agreement with the previously observed relationship between dry matter intake, which is higher during early lactation, and progesterone clearance; however, profits would be lost if cows were bred during late lactation when progesterone clearance and energy requirements are lower.

\section{Hepatic Catabolic Enzymes and Steroid Biotransformation}

The cytochrome P450 superfamily (CYP; located in the endoplasmic reticulum or microsomal cellular fractions) are involved in a number of pathways including endogenous vitamin D3 activation, metabolism of cholesterol to bile acids, metabolism of all major classes of steroid hormones (Waxman et al., 1991), and xenobiotic metabolism (Anzenbacher and Anzenbacherova, 2001). Waxman et al. (1991) determined that progesterone was primarily metabolized to $6 \beta$-hydroxyprogesterone and $16 \alpha$ hydroxyprogesterone along with two other unknown metabolites by CYP3A4, CYP3A3, CYP4B1, CYP3A5 and CYP2C8, in order of highest activity to lowest. In sheep liver, CYP2C and CYP3A metabolized progesterone to 21-hydroxyprogesterone 
(deoxycorticosterone) and 6 6 -hydroxyprogesterone at a rate of $270 \mathrm{pmol} / \mathrm{min} / \mathrm{mg}$ microsomal protein or $430 \mathrm{pmol} / \mathrm{min} / \mathrm{mg}$ microsomal protein, respectively (Murray, 1991; 1992). The total microsomal contributions to progesterone inactivation were determined to be $\sim 25 \%$ for CYP2C and $\sim 55 \%$ for CYP3A in sheep (Murray, 1991; 1992). In contrast to the sheep data, recent reports in dairy cows showed a negative correlation of in vivo endogenous progesterone concentrations with CYP2C activity, while CYP3A activity was not associated with endogenous progesterone concentrations (Sá Filho et al., 2009).

The aldo-keto reductase superfamily of enzymes are involved in the reduction of glucose, prostaglandin metabolism, generation of bile acids and reduction of steroids containing aldehyde or ketone groups (Penning et al., 2000; Barski et al., 2008; Kabututu et al., 2009). The cytosolic enzymes, aldo-keto reductase 1C subfamily (AKR1C), are involved in converting progesterone to $3 \alpha$-hydroxyprogesterone or $20 \alpha-$ hydroxyprogesterone metabolites in humans and rodents (Penning et al., 2000). In the human, all 4 isoforms of AKR1C (AKR1C1, AKR1C2, AKR1C3 and AKR1C4) were highly expressed in the liver (Penning et al., 2000). In mouse liver or kidney, 20 $\alpha$ hydroxyprogesteorne formation (AKR1C activity) occurred at a rate of $\sim 800$ or 400 $\mathrm{pmol} / \mathrm{min} / \mathrm{mg}$ cytosolic protein, respectively (Imamura et al., 2007). The second phase of steroid biotransformation, generation of a more hydrophilic pregnandiol metabolite, involves UDP-glucuronosyltransferase (UGT) enzymes, which conjugate the inactive hydroxysteroid metabolites with glucuronic acid. UGT1A and UGT2B have been implicated in glucuronidation of hydroxylated derivatives of C18, C19 and C21 steroids (Bowalgaha et al., 2007). 
Szotakova et al. (2004) examined protein expression and activity of CYP, AKR and UGT enzymes in pig, cattle, goat and sheep. Interspecies differences in CYP and AKR activity were found for all of the species tested. The conjugation of 4-nitrophenol (UGT activity) was highest in ovine microsomes and similar between caprine, bovine and porcine (Szotakova et al., 2004). From these studies, Szotakova et al. (2004) concluded that biotransformation of veterinary pharmaceuticals in domesticated species should be consistently tested on target species and not extrapolated from one species to another. Giantin et al. (2008) examined expression and activity for CYP and UGT enzymes in males of three different breeds of cattle (Charolais, Piedmontese and Blonde d'Aquitaine). Although, similar activities were observed across the different breeds, significant differences in mRNA expression were reported for both CYP and UGT enzymes, with the largest discrepancy in CYP mRNA expression and CYP activity in Charolais cattle (Giantin et al., 2008). In the rat, hepatic protein expression and CYP activity were consistently lower in pregnant versus non-pregnant age matched controls (Dean and Stock, 1975; He et al., 2005). The differences in metabolic enzyme expression across species, breed and physiological state (pregnant, cycling or lactating) illustrates a necessity for more studies in the lactating Holstein, which could be drastically different from common laboratory species, other breeds of cattle or non-lactating cows.

A relationship between cytochrome P450 expression and insulin was proposed when Barnnett et al. (1990) and Shimojo et al. (1993) observed an increased expression of CYP3A in insulin dependent diabetic rats (i.e. low insulin), which was reversed by insulin replacement. Smith et al. (2006) found a dose-dependent decrease in the fractional rate constant of progesterone decay in a murine hepatocyte cell-line challenged 
with increasing physiological concentrations of insulin. Utilizing the same cell-line and experimental conditions, Lemley et al. (2009) reported a dose-dependent decrease in the activities of both CYP2C and CYP3A after challenging hepatocytes with increasing physiological concentrations of insulin. Similar to the in vitro data, Smith et al. (2006) found a decrease in progesterone clearance in anestrus ewes orally gavaged with sodium propionate (gluconeogenic substrate) versus sodium acetate (energy control group). In a follow up experiment, Lemley et al. (2008a) found approximately a 50\% decrease in both hepatic CYP2C and CYP3A activity $1 \mathrm{~h}$ post-feeding in ovariectomized ewes supplemented with sodium propionate versus sodium acetate. The in vitro and in vivo experiments helped illustrate a model for decreasing steroid clearance by altering cytochrome P450 activity via elevated concentrations of insulin.

Recent observations in dairy cows have also linked elevated insulin concentrations with lower CYP2C and CYP3A mRNA expression. In dairy cows chronically exposed to high insulin via a hyperinsulinemic-euglycemic clamp (96 h exposure) we found a decrease in both CYP2C and CYP3A mRNA expression (Lemley et al., 2008b). It is well established that chemically induced insulin-dependent diabetes enhances the expression of cytochrome P450 2E1, 2B, 3A and 4A and that insulin administration to diabetic rats lowers the expression of these cytochrome P450s to basal levels (Barnnett et al., 1990). Both insulin and glucagon have been implicated in increasing or decreasing CYP3A expression and activity in rat hepatocytes (Saad et al., 1994). In these previous experiments, supraphysiological concentrations of insulin or glucagon modified cytochrome P450 mRNA expression after extended exposure (24, 48 or $96 \mathrm{~h}$ ). Longer exposure times combined with high concentrations of hormone may be 
misleading because actual in vivo hepatic exposure to elevated insulin or glucagon may be enough time to regulate enzyme activity post-translationally, while having little to no effect on mRNA expression (Berry and Skett, 1988). Zangar and Novak (1998) found a $50 \%$ decrease in CYP3A mRNA expression in hepatocytes treated with dimethyl sulfoxide for $48 \mathrm{~h}$, while both CYP3A protein expression and activity increased nearly 5 fold under the same culture conditions. These results are not surprising due to the evidence associated with specific substrates that regulate cytochrome P450 activity by decreasing or increasing protein turnover, which is independent of mRNA expression (Zangar and Novak, 1998).

\section{Nutrition, Energy Balance and Reproductive Performance}

Selection for milk production over the last 6 decades has been accompanied with a decrease in reproductive performance, which might be explained by increased metabolic stress and high-energy demands (Butler, 2000). Several researchers have reviewed the importance of nutritional status in relation to reproductive performance in lactating dairy cows (Van Knegsel et al., 2005; Roche, 2006; Garnsworthy et al., 2008a). A majority of these studies have attempted to reduce the extent and the duration of the negative energy balance post-calving by feeding high-energy diets, which attenuate the severe drop in insulin concentrations. Butler et al. (2006) found a $28 \%$ increase in plasma insulin and an 18\% increase in energy balance in early postpartum dairy cows drenched daily with $500 \mathrm{ml}$ of propylene glycol versus $500 \mathrm{ml}$ of water. A four day infusion of insulin at a constant rate of 0.3 or $1.0 \mu \mathrm{g} / \mathrm{kgBW} * \mathrm{~h}$ in dairy cows during 10 to 14 days post-calving caused a 2.6 fold or 8 fold increase in plasma insulin as well as $42 \%$ or $72 \%$ improvement in energy balance, respectively (Butler et al., 2003; 2004). Insulin 
infusions increased peripheral estradiol concentrations and tended to improve circulating testosterone in these studies. In early postpartum dairy cows fed a glucogenic $(26.6 \%$ starch), mixed (17.9\% starch) or lipogenic diet (10.4\% starch), Van Knegsel et al. (2007) found no difference in dry matter intake or energy intake between dietary treatments; however, energy balance was improved in multiparous cows fed the glucogenic diet compared to the mixed diet.

Resumption of normal endocrine signaling in the early postpartum cow has been associated with high-energy diets that promote insulin secretion (Chagas et al., 2007). Selection of high producing dairy cows has led to lower peripheral insulin concentrations, which accounts for lower uptake of glucose in insulin responsive adipose and muscle tissue, rendering high glucose availability for mammary tissue. High starch diets have been implicated in improving energy balance as well as stimulating production of steroids and secretion of growth factors (Butler et al., 2004; Leroy et al., 2008). Garnsworthy et al. (2008a) altered energy source in isoenergetic and isonitrogenous dairy rations (5 dietary levels of starch; $9,14,16,18$ and $23 \%$ starch). They reported increasing insulin concentrations in cows fed starch from 9 to $16 \%$ in the form of wheat; however, the postovulatory rise in progesterone was delayed in cows fed the highest starch containing $\operatorname{diet}(23 \%$ starch $)$ even though insulin concentrations $(\sim 0.07 \mathrm{nM})$ had already reached a plateau at $16 \%$ dietary starch. Gong et al. (2002) found that insulin-stimulating diets increased the percentage of cows ovulating by day 50 postpartum.

Garnsworthy et al. (2009) altered dietary treatments at the time of the first postpartum ovulation from a low glucogenic diet $(9.8 \%$ starch) to a high glucogenic diet (18.2\% starch), a high glucogenic diet to a low glucogenic diet, or continued feeding a 
low or high glucogenic diet throughout the experiment. Pregnancy rates were highest in cows fed the high glucogenic diet until the first postpartum ovulation and then switched to the low glucogenic diet during early pregnancy compared to the three other dietary variations. This may be due to the beneficial effect of insulin on early follicular development, leading to a shorter postpartum anestrus interval, and the negative effects of insulin on oocyte competence leading to higher embryonic loss (Chagas et al., 2007). Moreover, Green et al. (2005) found more advanced embryonic growth at day 5 postinsemination in cows with lower insulin concentrations and higher progesterone concentrations. Green et al. (2005) reported a negative association between insulin and progesterone concentrations during the post-ovulatory rise in progesterone. In contrast to this negative relationship, Koch (2008) found a 4-fold increase in insulin concentrations and a $25 \%$ increase in progesterone concentrations at 6.5 days of gestation in ewes treated periconceptionally with growth hormone. Therefore, insulin may have an embryo protective role if concentrations are high enough to alter endogenous concentrations of progesterone during early pregnancy. In beef heifers fed insulin-stimulating diets, Mann et al. (2003) reported an increase in early embryonic development compared to low insulin diets; however this result was not accompanied by any changes in plasma progesterone or insulin concentrations even though these diets were similar to the diets fed by Gong et al. (2002). Garnsworthy et al. (2008b) found decreased insulin concentrations in dairy cows supplemented with Mega-Lac at 23 and $30 \mathrm{~g} / \mathrm{kg}$ of dry matter versus 0,8 and $15 \mathrm{~g} / \mathrm{kg}$ of dry matter while starch was held constant across dietary treatments. Progesterone concentrations from $\mathrm{d} 3$ to 5 postovulation were elevated in cows supplemented with Mega-Lac at 23 and $30 \mathrm{~g} / \mathrm{kg}$ of dry matter, which may be due to 
increased production, decreased clearance of progesterone or both (Garnsworthy et al., 2008b).

A portion of the early embryonic and fetal loss may be accounted for by inadequate concentrations of progesterone due to increased rates of steroid inactivation, deficiencies in luteal function, or a combination of both (Inskeep and Dailey, 2005).

Selvaraju et al. (2002) found elevated peripheral concentrations of progesterone in crossbred repeat breeding cows $(\mathrm{n}=21)$ treated with long-acting bovine insulin. Those cows showed a $46 \%$ increase in plasma insulin concentrations after injection as well as a 17 and $15 \%$ increase in plasma progesterone on $\mathrm{d} 8$ and 10 of the estrus cycle, respectively; although, pregnancy rates were not different between the insulin treated (63.6\%) and saline treated (40.0\%) groups (Selvaraju et al., 2002). These higher concentrations of progesterone may be due to a decrease in hepatic clearance brought about by elevated insulin concentrations. Miyoshi et al. (2001) reported shorter time interval in days to first ovulation in cows $(\mathrm{n}=36)$ drenched daily with $500 \mathrm{ml}$ of propylene glycol. Cumulative plasma progesterone concentrations during the first estrous cycle in the propylene glycol (42.9 ng) and control (29.4 ng) cows were not different nor were the first service conception rates between the propylene glycol (57.1\%) and control (33.0\%) groups (Miyoshi et al., 2001). In a larger propylene glycol drenching experiment, Hidalgo et al. (2004) found a 33\% increase in insulin concentrations, a $27 \%$ increase in progesterone concentrations and a $33 \%$ increase in pregnancy rates in cattle $(\mathrm{n}=286)$ drenched daily with $250 \mathrm{ml}$ of propylene glycol prior to embryo transfer. In non-lactating ovariectomized cows divided into groups of high and low plasma concentrations of insulin before feeding, Moriel et al. (2008) reported 
elevated plasma progesterone concentrations (from an exogenous source) at 1 hour post feeding in the high versus the low insulin group, which would suggest a protective role for insulin in decreasing progesterone clearance in vivo. However, these effects were reversed at 5 hours post-feeding, where the low insulin group had the highest concentrations of progesterone (Moriel et al., 2008), which may be an indicator of progesterone clearance, progesterone absorption into the periphery or both. 


\section{STATEMENT OF THE PROBLEM}

Annual milk production for an average Holstein dairy cow was approximately $5,000 \mathrm{~kg}$ of milk in the early 1950s (Butler, 2000). Progess in nutritional management and intensive genetic selection for milk yield over the last 6 decades has doubled this average to approximately $10,000 \mathrm{~kg}$ of milk per year. Coincident with selection for high producing cows has had negative consequences on reproductive performance. In the early 1950 s, conceptions rates were approximately $65 \%$, while several researchers have reported 35\% conception rates in recent years (Butler, 2000). During early gestation, progesterone exposure increases uterine secretions of nutrients and growth factors that advance early embryonic growth and development. By analyzing several independent studies, Mann and Lamming (1999) reported a significant increase in pregnancy rates $(5 \%)$ in dairy cows supplemented with exogenous progesterone in the form of a CIDR during the first few weeks of gestation.

Starbuck et al. (2004) reported increased pregnancy retention to week 7 and 9 in dairy cows classified as having medium or high concentrations of progesterone during week 5 of gestation compared to cows classified as low peripheral concentrations of progesterone. Supplementing cows classified as having low concentrations of progesterone with an exogenous source of progesterone in the form of a CIDR, which increases peripheral concentrations by approximately $1 \mathrm{ng} / \mathrm{ml}$, would only improve classification from low to medium concentrations of progesterone in a select few cows. Therefore, supplementing progesterone in the form of a CIDR only partially masks the high rates of progesterone clearance and does not address the issue of elevated feed intake and excessive progesterone clearance in the high producing dairy cow. 
Peripheral concentrations of progesterone are controlled by both production and catabolism of the steroid molecule. In the diary cow, the primary source of progesterone is the corpus luteum and several studies have addressed luteal function in the lactating dairy cow. However, a paucity of information exists on progesterone clearance in the lactating dairy cow, and even fewer studies have characterized the hepatic progesterone catabolic enzymes (CYP2C, CYP3A and AKR1C) in the lactating dairy cow. Rhinehart et al. (2009) suggested that progesterone clearance had a greater contribution to total peripheral concentrations of progesterone compared to progesterone production in pregnant dairy cows. Independent reports in sheep and lactating dairy cows have shown a strong positive association between dry matter intake, liver blood flow and the metabolic clearance rate of progesterone (Parr et al., 1993a; Parr et al., 1993b; Sangsritavong et al., 2002). Feeding a high yielding dairy cow half of her nutrient requirements will increase circulating concentrations of progesterone and could improve uterine and embryonic exposure to progesterone during early gestation; however, decreasing a high producing dairy cows feed intake will decrease her milk yield because of the strong positive association between dry matter intake and milk yield.

Shortly after parturition, a dairy cow enters into negative energy balance, which lengthens the duration of postpartum anestrus. To maximize milk yield and herd efficiency cows need to be bred and pregnant by 110 days postpartum for a 12.5 to 13.5 month calving interval. Every day open past 110 days postpartum can cost a producer approximately $\$ 2.50$ per day (De Vries et al., 2006). If we consider a 70 day postpartum voluntary waiting period and a $35 \%$ first service conception rate a 100 head operation could be losing approximately $\$ 10,000$ per year due to low pregnancy rates. Throughout 
the United States, which has nearly 9 million dairy cows, the industry is losing approximately 900 million dollars due to failure to conceive to first insemination.

Altering the type of energy provided can affect reproductive performance and alter hormonal profiles in dairy cows. However, the majority of these studies failed to address whether altered hormonal profiles were due to production, clearance of progesterone or a combination of both. The current experiments were performed to help describe the relationship between the type of energy provided and hepatic clearance of progesterone in early lactating dairy cows. 


\section{EFFECT OF A HIGH CORNSTARCH DIET ON HEPATIC CYTOCHROME P450 2C AND 3A ACTIVITY AND PROGESTERONE HALF-LIFE IN DAIRY cows $^{1}$}

C. O. Lemley, T. A. Wilmoth, L. R. Tager, K. M. Krause, and M. E. Wilson ${ }^{2}$

Division of Animal and Nutritional Sciences, Davis College of Agriculture, Natural Resources and Design, West Virginia University, Morgantown, West Virginia, 26506

A paper published in the Journal of Dairy Science ${ }^{3}$

\footnotetext{
${ }^{1}$ This work is published with the approval of the Director of West Virginia Agriculture and Forestry Experiment Station as scientific paper 3054. This project was supported by National Research Initiative Competitive Grant no. 2008-35203-04503 from the USDA Cooperative State Research, Education, and Extension Service and Hatch project 468 (NE 1007).

${ }^{2}$ Corresponding author: mwilso25@wvu.edu

${ }^{3}$ Reprinted with the permission of the American Dairy Science Association from the Journal of Dairy Science 93:1012-1021 (2010).

http://www.journalofdairyscience.org/article/PIIS0022030210000688/abstract
} 


\begin{abstract}
In the cow inadequate concentrations of progesterone during gestation may lead to an abrupt termination of pregnancy. The primary organ involved in progesterone catabolism is the liver, which contains an abundance of cytochrome P450 isozymes (EC 1.14.14.1; mixed function monooxygenases). The objectives of the current experiment were to determine the effect of feeding two isoenergetic and isonitrogenous diets formulated to cause divergent insulin secretion, on hepatic cytochrome P450 2C (CYP2C) and 3A
\end{abstract} (CYP3A) activity, as well as the resulting biological half-life of progesterone. Twentytwo Holstein cows averaging $80 \pm 7$ days in milk (DIM) were randomly assigned to either a high cornstarch or a high fiber diet in a cross-over experimental design consisting of two $14 \mathrm{~d}$ periods. Dry matter intake (DMI), milk yield, milk lactose yield and milk lactose percentage were similar between the two diets. Milk fat yield and milk fat percentage were higher in cows fed the high fiber diet, while milk protein yield tended to be higher and milk protein percentage was higher in cows fed the high cornstarch diet. Energy balance (EB) tended to be improved by $57 \%$ in cows consuming the high cornstarch diet. Insulin concentrations at the time of liver biopsy $(3.16 \pm 0.04 \mathrm{~h}$ postfeeding) were elevated by $44 \%$ in cows consuming the high cornstarch diet versus the high fiber diet. Cytochrome P450 2C activity was decreased by 45\%, while CYP3A activity tended to be lowered by $34 \%$ in cows consuming the high cornstarch diet. Cytochrome P450 2C mRNA expression tended to be decreased by $21 \%$ in cows fed the high cornstarch diet, while CYP3A mRNA expression was not different between the dietary treatments. The fractional rate constant of progesterone decay was not different between the two diets; however, the half-life of progesterone tended to be longer in cows 
fed the high cornstarch diet versus the high fiber diet ( 85 versus 64 minutes, respectively). In summary, cows consuming the high cornstarch diet had elevated insulin concentrations, lower hepatic CYP2C and CYP3A activity and tended to have a longer progesterone half-life compared to cows consuming the high fiber diet. Feeding diets that stimulate insulin secretion could alter progesterone clearance during lactation, when dairy cows have elevated rates of progesterone inactivation due to high-energy demands and elevated DMI.

Key words: progesterone, insulin, cytochrome P450, dairy cow 


\section{Introduction}

Several researchers have reviewed the importance of nutritional status in relation to reproductive performance in lactating dairy cows (Van Knegsel et al., 2005; Roche, 2006; Garnsworthy et al., 2008a). The severe negative energy balance (EB) following calving has been correlated with several reproductive dysfunctions and attempts to improve EB during early lactation can cause a faster restoration of cyclicity and increase peripheral concentrations of steroids (Butler et al., 2004). Resumption of normal endocrine signaling in the early postpartum cow has been associated with high-energy diets that promote insulin secretion (Chagas et al., 2007). High starch diets have been implicated in improving EB as well as stimulating production of steroids and secretion of growth factors (Leroy et al., 2008). Added energy in the form of a once daily propylene glycol drench has been reported to increase peripheral concentrations of insulin, concentrations of progesterone and pregnancy rates in dairy cows (Hidalgo et al., 2004).

A portion of the early embryonic and fetal loss may be accounted for by inadequate concentrations of progesterone due to increased rates of steroid inactivation, deficiencies in luteal function, or a combination of both (Inskeep and Dailey, 2005). Some researchers have found no change or increased first service conception rates after supplementing cows with progesterone in the form of a controlled internal drug-releasing device (CIDR), which can increase peripheral concentrations of progesterone by approximately $1 \mathrm{ng} / \mathrm{ml}$ (Larson et al., 2007; Stevenson et al., 2007). However, supplementation with progesterone partially masks the high rates of progesterone clearance in dairy cows and fails to address the issue of excessive steroid clearance due to elevated feed intake during early lactation. Steroid inactivation occurs primarily in the 
liver and independent reports in sheep and cattle have shown a positive relationship between metabolic clearance rate of progesterone and DMI (Parr et al., 1993a; Sangsritavong et al., 2002). The relationship between DMI and excessive steroid clearance may be attributed to an increase in steroid delivery to the liver via an equal and proportionate increase in liver blood flow (Parr et al., 1993b).

The first phase of steroid biotransformation involves hydroxylation of the steroid nucleus by the mixed function monooxygenases cytochrome P450 2C (CYP2C) and cytochrome P450 3A (CYP3A), as well as contributions from the aldo-keto reductase family (You, 2004; Penning et al., 2000). A relationship between cytochrome P450 expression and insulin was proposed when Barnnett et al. (1990) and Shimojo et al. (1993) observed an increased expression of CYP3A in insulin dependent diabetic rats (i.e. low insulin), which was reversed by insulin replacement. Smith et al. (2006) found a dose-dependent decrease in the fractional rate constant of progesterone decay in a murine hepatocyte cell-line challenged with increasing physiological concentrations of insulin. Utilizing the same cell-line and experimental conditions, Lemley et al. (2009) reported a dose-dependent decrease in the activities of both CYP2C and CYP3A after challenging hepatocytes with increasing physiological concentrations of insulin. Similar to the in vitro data, Smith et al. (2006) found a decrease in progesterone clearance in anestrus ewes orally gavaged (drenched) with sodium propionate (gluconeogenic substrate) versus sodium acetate (energy control group). In a follow up experiment, Lemley et al. (2008a) found approximately a 50\% decrease in both hepatic CYP2C and CYP3A activity at $1 \mathrm{~h}$ post-feeding in ovariectomized ewes supplemented with sodium propionate versus 
sodium acetate. The in vitro and in vivo experiments helped illustrate a model for decreasing steroid clearance by altering cytochrome P450 activity via insulin signaling.

Recent observations in dairy cows have also linked elevated insulin concentrations with lower CYP2C and CYP3A mRNA expression (Lemley et al., 2008b); however, we were unable to detect enzyme activity in frozen liver tissue and due to the use of early postpartum anestrus cows we could not detect peripheral concentrations of progesterone. Therefore, the objectives of the current experiment were to determine the effect of feeding two isoenergetic diets formulated to cause divergent insulin secretion on hepatic CYP2C and CYP3A activity as well as the resulting biological half-life of progesterone.

\section{Materials and Methods}

\section{Animals and Feeding}

Twenty-two Holstein dairy cows (8 primiparous and 14 multiparous) were trained to acquire feed from the Calan Broadbent Feeding System (American Calan, Northwood, $\mathrm{NH}$ ) at the West Virginia University Animal Science Farm (Morgantown, WV). Three separate replicates were conducted beginning in the fall of $2007(n=6)$, the spring of $2008(\mathrm{n}=8)$ and the fall of $2008(\mathrm{n}=8)$. Experimental procedures and protocols were approved by the West Virginia University Animal Care and Use Committee \#07-0503. Cows were randomly assigned to a high cornstarch diet or an isoenergetic and isonitrogenous high fiber diet (Table 1). Cows were provided each diet as a TMR with $50 \%$ of the diet fed at each feeding. The cross-over experimental design contained two $14 \mathrm{~d}$ periods, with $10 \mathrm{~d}$ of diet acclimation and the remaining $4 \mathrm{~d}$ used for sampling (Figure 1). Cows were $80 \pm 7 \mathrm{DIM}$ at the beginning of the experiment, and milked twice 
Table 1. Experimental diet composition and average ( \pm SEM) nutrient composition from all three replicates.

\begin{tabular}{|c|c|c|}
\hline Diet Composition & $\begin{array}{l}\text { High } \\
\text { Cornstarch }\end{array}$ & $\begin{array}{l}\text { High } \\
\text { Fiber }\end{array}$ \\
\hline \multicolumn{3}{|l|}{ Ingredient, $\%$ of DM } \\
\hline Corn silage & 31.1 & 36.7 \\
\hline Chopped alfalfa hay & 17.8 & 15.3 \\
\hline Ground corn & 12.5 & 6.1 \\
\hline Corn gluten meal & 1.8 & 1.5 \\
\hline Corn gluten feed & 5.4 & 5.1 \\
\hline Wheat middlings & 7.3 & 5.2 \\
\hline Soybean meal (47\% CP) & 8.5 & 5.0 \\
\hline Soybean hulls & - & 23.1 \\
\hline Refined cornstarch ${ }^{1}$ & 15.1 & - \\
\hline Mega-Lac ${ }^{2}$ (Ca-soaps of fatty acids) & - & 1.9 \\
\hline Di-calcium phosphate & 0.29 & 0.08 \\
\hline Limestone & 0.1 & - \\
\hline Magnesium oxide & 0.04 & 0.04 \\
\hline Trace mineral salt & 0.13 & 0.13 \\
\hline Vitamin premix ${ }^{3}$ & 0.08 & 0.08 \\
\hline \multicolumn{3}{|l|}{ Nutrient composition, \% of DM } \\
\hline $\mathrm{DM}, \%$ & $65 \pm 1$ & $61 \pm 1$ \\
\hline NDF & $28.9 \pm 0.5$ & $39.0 \pm 0.5$ \\
\hline $\mathrm{ADF}$ & $16.1 \pm 0.3$ & $25.2 \pm 0.3$ \\
\hline $\mathrm{NFC}^{4}$ & $50.3 \pm 0.5$ & $38.5 \pm 0.5$ \\
\hline Starch & $35.3 \pm 1.0$ & $19.2 \pm 0.4$ \\
\hline $\mathrm{CP}$ & $13.9 \pm 0.2$ & $13.5 \pm 0.1$ \\
\hline Ether extract & $2.0 \pm 0.1$ & $2.8 \pm 0.1$ \\
\hline Ash & $4.8 \pm 0.2$ & $5.6 \pm 0.1$ \\
\hline $\mathrm{NE}_{\mathrm{L}}{ }^{5} \mathrm{Mcal} / \mathrm{kg} \mathrm{DM}$ & 1.58 & 1.58 \\
\hline
\end{tabular}

${ }^{1}$ Grain Processing Corporation, Muscatine, IA. Moisture $<12.5 \%$, pH 5.0 - 7.0, ash $<$ $0.5 \%$, protein $<0.35 \%$; based on a $100 \mathrm{~g}$ sample (as fed), $89.9 \mathrm{~g}$ starch, $0 \mathrm{~g}$ fat, $0.3 \mathrm{~g}$ protein.

${ }^{2}$ Ca-soaps of fatty acids (Church and Dwight, Inc., Princeton, NJ).

${ }^{3}$ Vitamin ADE premix (North American Nutrition Companies, Inc, Brookville, $\mathrm{OH}$ ); 9,920.9 IU/g of vitamin A; 2,204.6 IU/g of vitamin $\mathrm{D}_{3} ; 4.4 \mathrm{IU} / \mathrm{g}$ of vitamin $\mathrm{E}$.

${ }^{4} \mathrm{NFC}=100-(\% \mathrm{NDF}+\% \mathrm{CP}+\%$ Ether extract $+\%$ Ash $)$.

${ }^{5}$ Based on tabular values (NRC, 2001). 
Twice daily collection of milk samples

$10 \mathrm{~d}$ of diet adaptation on $\mathrm{d} 11,12,13$ and 14

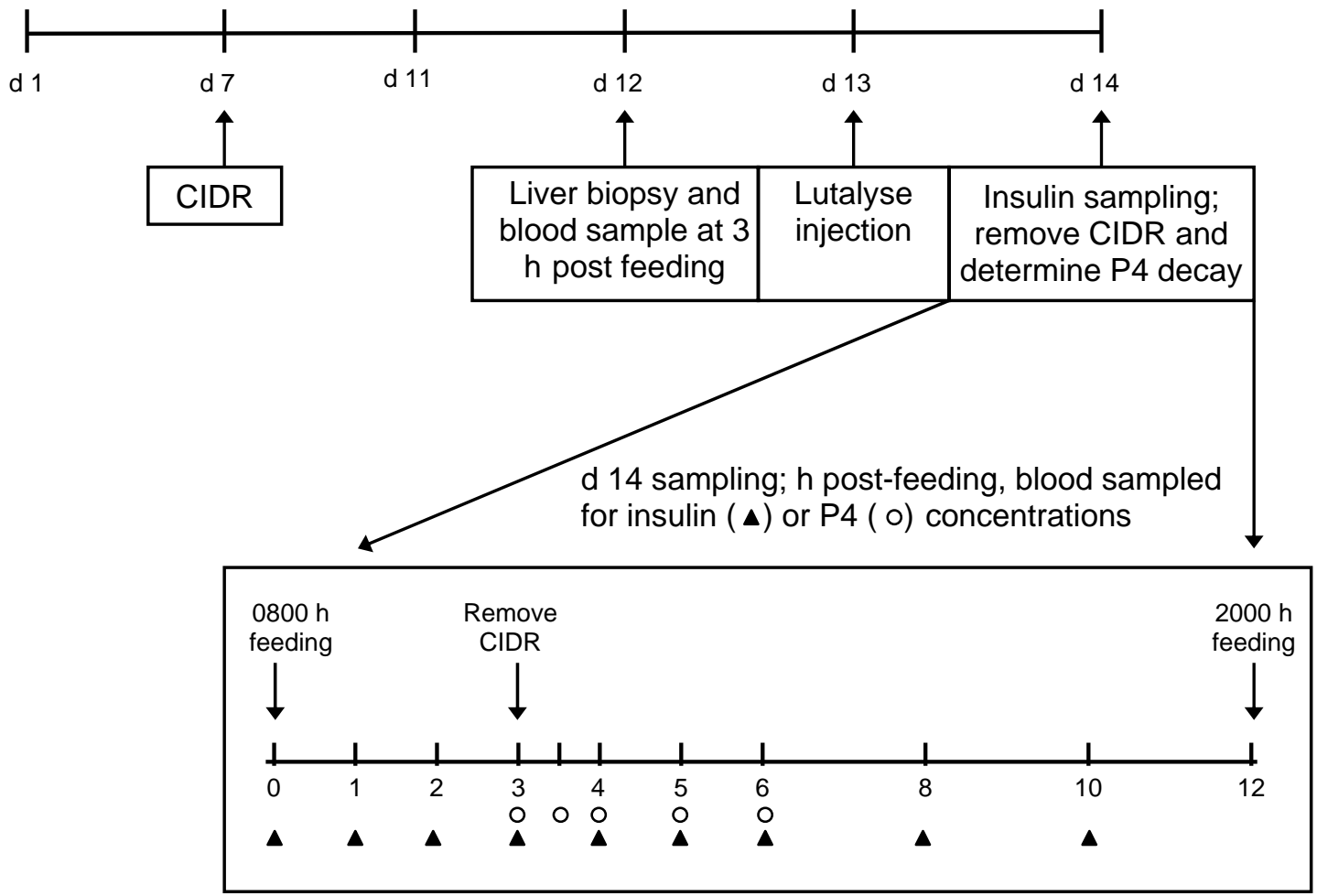

Figure 1. The cross-over experimental design consisted of two $14 \mathrm{~d}$ periods. Cows were acclimated to their new diets during the first $10 \mathrm{~d}$ of the experiment. Samples were collected on d 11, 12, 13 and 14. On d 14 plasma insulin (closed triangles) concentrations were determined at $0,1,2,3,4,5,6,8,10 \mathrm{~h}$ post-feeding and plasma progesterone ( $\mathrm{P} 4$; open circles) concentrations were determined after CIDR removal at 3 , $3.5,4,5$ and 6 h post-feeding. 
daily at 0800 and $2000 \mathrm{~h}$ and feed was provided directly after each milking. Dry matter intake was kept constant for each cow across treatments in order to avoid confounding effects with DMI with differences due to dietary treatment. The feed allocated to each cow was fixed across dietary treatments and based on her voluntary intake shortly after completing her training to the Calan gate system and during the first $7 \mathrm{~d}$ preceding the experiment. On d 7, cows received a CIDR (Pfizer Inc., New York, NY) containing 1.38 $\mathrm{g}$ of progesterone, which was removed $3 \mathrm{~h}$ post-feeding on d 14. After removal of CIDRs between periods 1 and 2 cows were monitored twice daily for estrous behavior and all cows used in the present study were determined to be cycling. On d 13, $25 \mathrm{mg}$ of lutalyse (Pfizer Inc., New York, NY) was administered to each cow. Average milk production was recorded and milk samples were collected at each milking on d 11, 12, 13 and 14, and samples were analyzed for lactose, protein and fat percent (Dairy One Inc., Ithaca, NY). Two TMR samples were collected during each sampling period. Average BW $(579 \pm 7 \mathrm{~kg}$ ) was determined by weighing cows before milking, after milking and halfway between milkings on d 11, 12 and 13 of each period, respectively. Feed intake, milk composition and body weight were used to estimate EB over the $4 \mathrm{~d}$ sampling period using the equation, $\mathrm{EB}=\mathrm{NE}_{\mathrm{C}}-\left(\mathrm{NE}_{\mathrm{L}}+\mathrm{NE}_{\mathrm{M}}\right)$, where $\mathrm{NE}_{\mathrm{C}}=1.58 \mathrm{Mcal} / \mathrm{kg} * \mathrm{DMI}$, $\mathrm{NE}_{\mathrm{L}}=\mathrm{MY} *((0.0929 * \%$ fat $)+(0.0563 * \%$ protein $)+(0.0395 * \%$ lactose $))$ and $\mathrm{NE}_{\mathrm{M}}=$ $\left(\mathrm{BW}^{0.75}\right)^{*} 0.08$ (net energy consumed, $\mathrm{NE}_{\mathrm{C}}$; net energy used for lactation, $\mathrm{NE}_{\mathrm{L}}$; net energy required for maintenance, $\mathrm{NE}_{\mathrm{M}}$; $\left.\mathrm{NRC}, 2001\right)$.

\section{Microsomal Preparation and Enzymatic Activity}

On $\mathrm{d} 12$, the $0800 \mathrm{~h}$ milking and feeding was staggered for pairs of cows by 15 min to assure similar liver biopsy times post-feeding $(3.16 \pm 0.04 \mathrm{~h}$ post-feeding $)$. 
Briefly, hair was removed from the animals' right side and the skin was scrubbed twice with betadine (Columbus Serum, Columbus, $\mathrm{OH}$ ). After determining the location of the tenth intercostal space, $2 \%$ lidocaine hydrochloride (Columbus Serum, Columbus, $\mathrm{OH}$ ) was administered as a local anesthetic. The skin was punctured using a scalpel and the liver samples were collected using a biopsy needle machined at the West Virginia University Physics Department (Morgantown, WV) following the specifications of Swanson et al. (2000). Immediately after the liver biopsy a blood sample was collected via jugular venipuncture into pre-chilled EDTA containing tubes and used to determine insulin concentrations by RIA (Lemley et al., 2008a). Enzymatic activity was assessed in fresh liver samples following our previous protocol (Lemley et al., 2008a). Briefly, liver samples were submerged in phosphate buffer and homogenized using a Dounce homogenizer. Microsomes were collected and concentrated using differential centrifugation techniques (modified from Nelson et al., 2001). Homogenized tissue was centrifuged at 10,000 $\mathrm{xg}$ for $10 \mathrm{~min}$. Pellets were discarded and the supernatants were centrifuged at 100,000 $\mathrm{xg}$ for $60 \mathrm{~min}$. The microsomal pellets were resuspended in phosphate buffer and the activity of cytochrome c reductase (product number CY0100; Sigma Chemical Co., St. Louis, MO) was determined to standardize samples. Cytochrome P450 2C activity was measured as the non-ketoconazole-inhibitable, omeprazole-dependent oxidation of nicotinamide adenine dinucleotide phosphate (NADPH). Microsomes were pre-incubated for 15 min with $250 \mu M$ ketoconazole. Enzymatic reactions contained CYP3A inhibited microsomes, $2.5 \mathrm{mM}$ omeprazole and $250 \mu M$ NADPH. Cytochrome P450 3A activity was measured as the nifedipinedependent oxidation of NADPH. Enzymatic reactions contained fresh microsomes, 200 
$\mu M$ nifedipine and $250 \mu M$ NADPH. All solutions were added to UV star 96-well plates (PGC Scientifics, Frederick, MD) and the oxidation of NADPH was determined by measuring the amount of light absorbed at $340 \mathrm{~nm}$ for $5 \mathrm{~min}$. The extinction coefficient for NADPH $\left(62201 / \mathrm{mol}^{*} \mathrm{~cm}\right)$ was used to calculate oxidized NADPH per unit time.

\section{CYP2C and CYP3A mRNA expression}

Liver samples were stored at $-80{ }^{\circ} \mathrm{C}$ until total cellular RNA was extracted using TRIzol reagent (Invitrtogen, Carlsbad, CA) and precipitated with 2-propanol following the manufacturers protocol. Concentrations of RNA in each sample were determined using a Nanodrop ND-1000 spectrophotometer (NanoDrop Technologies, Wilmington, DE). One $\mu$ g of RNA was electrophoresed through a $1.5 \%$ agarose gel to determine sample purity and for visualization of $28 \mathrm{~S}$ and $18 \mathrm{~S}$ rRNA bands. Real-time reverse transcriptase-PCR was performed as previously described (Costine et al., 2007). Briefly, samples were diluted to $1 \mu \mathrm{g} \mathrm{RNA} / \mu 1$ and reverse transcribed using moloney murine leukemia virus reverse transcriptase (Promega, Madison, WI) following the manufacturers protocol. Beta-actin was used as a reference gene, and bovine CYP2C and CYP3A genes were chosen due to their homology to the human progesterone catabolic enzymes CYP2C19 and CYP3A4 (National Center for Biotechnology Information; http://www.ncbi.nlm.nih.gov/; Kijas et al., 2006; Pruitt et al., 2007; Sonstegard et al., 2002). Primers for $\beta$-actin (accession no. NM_001009784; forward: 5'ATGAGCTGCCCGATGGTC-3'; reverse: 5'-GGATGTCCACGTCACACTTC-3'), CYP2C (accession no. XM_587518; forward: 5'-TATGGACTCCTGCTCCTGCT-3'; reverse: 5'-CATCTGTGTAGGGCATGCAG-3') and CYP3A (accession no. BT030557; forward: 5'-GTGCCAATCTCTGTGCTTCA-3'; reverse: 5'-CCAGTTCCAAAAGG- 
CAGGTA-3') were synthesized (Integrated DNA Technologies, Inc., Coralville, IA). Amplification was optimal at an annealing temperature of $63.1{ }^{\circ} \mathrm{C}$ and efficiencies for $\beta$ actin, CYP2C and CYP3A were 1.89, 1.95 and 1.85 (theoretical yields of 94.5, 97.5 and 92.5\%, respectively). The relative abundance of mRNA for CYP2C and CYP3A were corrected for PCR efficiency, standardized using $\beta$-actin and expressed relative to a pooled sample, as described by Costine et al. (2007).

\section{Progesterone and Insulin Concentrations}

On d 14 at $0700 \mathrm{~h}$, a jugular vein was catheterized with Tygon tubing (Thermo Fisher Scientifics, Waltham, MA; $1.02 \mathrm{~mm}$ ID and $1.78 \mathrm{~mm} \mathrm{OD).} \mathrm{Catheters} \mathrm{were} \mathrm{gas}$ sterilized prior to use with Anprolene gas ampules (Andersen Products Inc., Haw River, NC) and kept patent by flushing with $10 \mathrm{U} / \mathrm{ml}$ heparin (Columbus Serum Co., Columbus, $\mathrm{OH}$ ). A blood sample was collected at the time of catheterization and used as $\mathrm{h} 0$.

Following the $0800 \mathrm{~h}$ milking and feeding on $\mathrm{d} 14$, blood samples were collected at 1, 2, $3,3.5,4,5,6,8$ and $10 \mathrm{~h}$ post-feeding. Exogenous progesterone in the form of a CIDR was removed following the $3 \mathrm{~h}$ blood collection. Jugular blood samples were collected into pre-chilled EDTA containing tubes. Blood samples from h 3, 3.5, 4, 5 and 6 were used to determine progesterone decay. Briefly, the fractional rate constants of progesterone decay $(\mathrm{k})$ were calculated for each individual cow using SigmaPlot 8.0 (Aspire Software International, Ashburn, VA) using the equation $\mathrm{P}_{t}=\mathrm{P}_{\mathrm{o}} \mathrm{e}^{-\mathrm{kt}}\left(\mathrm{P}_{\mathrm{t}}\right.$, progesterone concentrations at any given time; $\mathrm{P}_{\mathrm{o}}$, initial progesterone concentrations; $\mathrm{t}$, time), which describes a first order exponential decay curve (Lemley et al., 2008a). The fractional rate constant of progesterone decay $(\mathrm{k})$ was then used to calculate the half-life of progesterone using the equation, $\mathrm{t}_{1 / 2}=\ln (2) / \mathrm{k}$. Plasma progesterone concentrations 
were determined using RIA (Sheffel et al., 1982) with a sensitivity of $100 \mathrm{pg} / \mathrm{ml}$ and intra- and inter-assay CV of 4.2 and $7.1 \%$, respectively. Insulin concentrations over the $10 \mathrm{~h}$ sampling period were determined using RIA (Lemley et al., 2008a) with a sensitivity of $0.05 \mathrm{nM}$ and intra- and inter-assay $\mathrm{CV}$ of 3.9 and $6.5 \%$, respectively. Insulin response over the $10 \mathrm{~h}$ sampling period was further assessed by calculating insulin area under the curve using SigmaPlot 8.0 (Aspire Software International, Ashburn, VA).

\section{Feed Analysis}

Dry matter of diets was determined by oven drying at $60{ }^{\circ} \mathrm{C}$ for $48 \mathrm{~h}$. Ether extraction of diets was performed according to AOAC (1995) using a Soxtec Foss Tecator (Foss Analytical, Hillerød, Denmark). Ash content was determined by ashing at $500{ }^{\circ} \mathrm{C}$ for $16 \mathrm{~h}(\mathrm{AOAC}, 1995)$. Neutral detergent fiber and ADF content were determined using an Ankom 200 Fiber Analyzer (Ankom Technology Corp, Macedon, NY). Total nitrogen and crude protein was analyzed according to AOAC (1995) using an automated Tecator digestion system (Tecator, Inc., Herndon, VA). Sugars in the diet were determined by the extraction procedure adapted from Deriaz (1961). Reducing sugars were determined spectrophotometrically with potassium ferricyanide. Starch content of the diets was determined by the procedure of Smith (1969).

\section{Statistical Analysis}

The effects of diet on dependent variables were tested with the MIXED procedure of SAS (SAS software version 9.1, SAS Institute Inc., Cary, NC). The model statement included replicate, period (period that dietary treatment was applied), order (order of dietary treatments), parity and diet while DIM was used as a covariate. Cow within order 
was considered random and means were separated using the PDIFF option of the

LSMEANS statement. Insulin concentrations were analyzed as repeated measurements using an autoregressive covariance structure, and means were separated using the PDIFF option of the LSMEANS statement. Pearson correlation coefficients were determined using the CORR procedure of SAS. Least square means and SEM are reported. Trends were declared at $P<0.10$ and $P>0.05$. Statistical significance was declared at $P \leq 0.05$.

\section{Results}

Dry matter intake, milk yield, milk lactose percent and milk lactose yield were similar (Table 2) between the two experimental diets. Milk fat percentage was decreased by $11 \%(P<0.05)$, while milk protein percentage was increased by $7 \%(P<0.001)$ in cows consuming the high cornstarch diet versus the high fiber diet (Table 2). Milk fat yield was decreased by $10 \%(P<0.05)$, while milk protein yield showed a trend $(P=$ 0.06 ) for a $7 \%$ increase in cows consuming the high cornstarch diet versus the high fiber diet (Table 2). Energy balance tended $(P=0.07)$ to be improved in cows consuming the high cornstarch diet compared to the high fiber diet (Table 2). Effect of parity was not significant for all variables measured.

Average insulin area under the curve, generated from a $10 \mathrm{~h}$ blood sampling period, increased $(P<0.005)$ by $20 \%$ in cows consuming the high cornstarch diet versus the high fiber diet (Figure 2). Average plasma insulin concentrations at the time of liver biopsy $(3.16 \pm 0.04 \mathrm{~h}$ post-feeding) were elevated $(P<0.005)$ by $44 \%$ in cows consuming the high cornstarch diet versus the high fiber diet (Figure 2). Cytochrome P450 2C activity was decreased $(P<0.05)$ by $45 \%$ in cows fed the high cornstarch 
Table 2. Effect of a high cornstarch versus a high fiber diet on DMI, milk production and energy balance.

\begin{tabular}{lcccc}
\hline & High & High & & \\
Dependent variable & Cornstarch & \multicolumn{1}{l}{ Fiber } & SEM & $P$ value \\
\hline DMI, kg/d & 19.75 & 18.81 & 0.54 & 0.21 \\
Milk yield, kg/d & 27.53 & 27.10 & 1.36 & 0.66 \\
Fat, \% & 3.44 & 3.86 & 0.15 & 0.03 \\
Fat yield, kg/d & 0.94 & 1.05 & 0.06 & 0.04 \\
Protein, \% & 3.00 & 2.80 & 0.07 & $<0.001$ \\
Protein yield, kg/d & 0.82 & 0.76 & 0.04 & 0.06 \\
Lactose, \% & 4.75 & 4.76 & 0.05 & 0.47 \\
Lactose yield, kg/d & 1.31 & 1.30 & 0.07 & 0.82 \\
Energy balance, Mcal/d & 3.44 & 1.49 & 0.91 & 0.07 \\
\hline
\end{tabular}




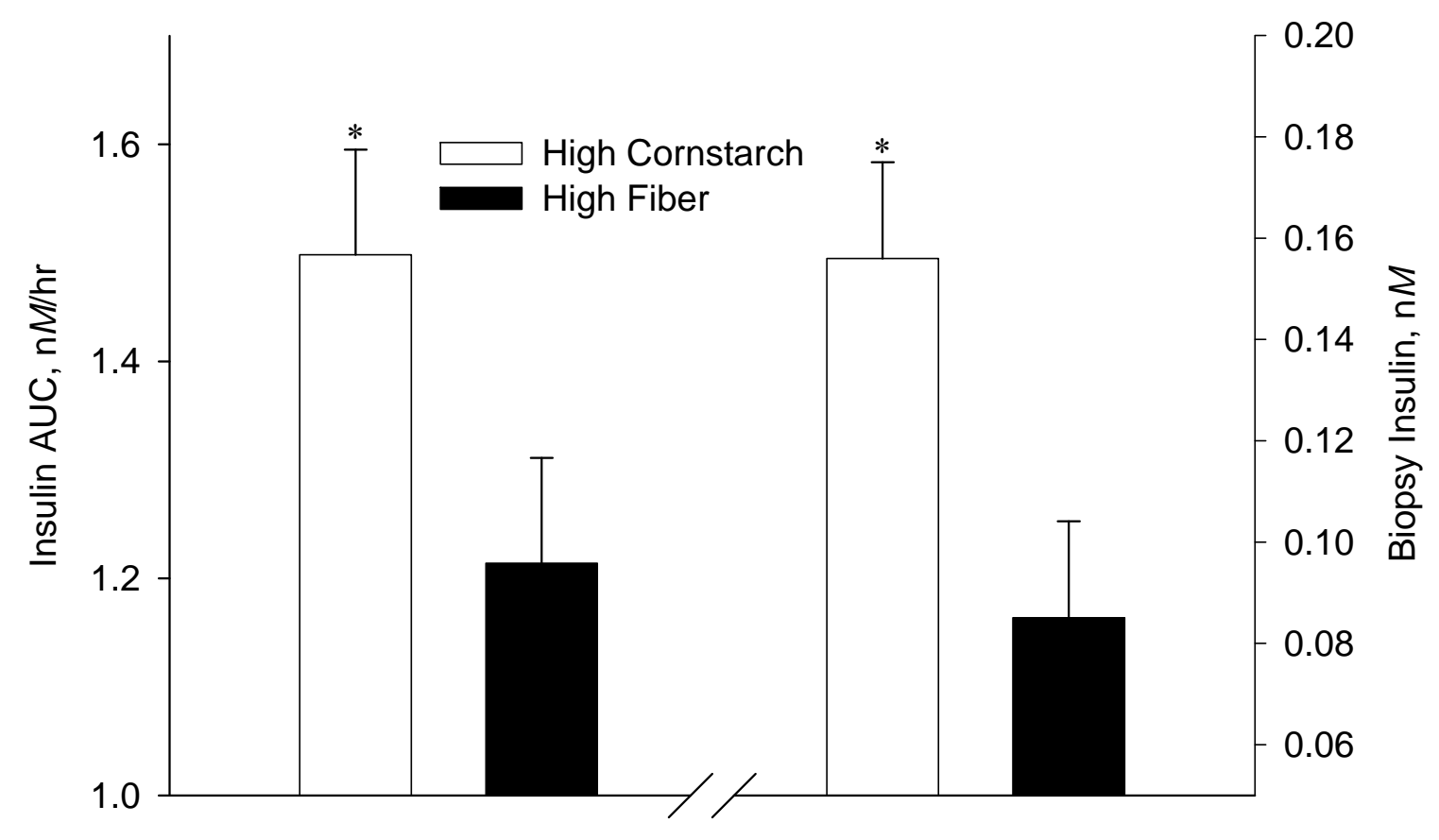

Figure 2. Insulin area under the curve (AUC; left two bars) and average insulin concentrations (right two bars) at the time of liver biopsy $(3.16 \pm 0.04 \mathrm{~h}$ post-feeding) in cows consuming a high cornstarch diet (open bars) or a high fiber diet (closed bars). Asterisk indicates $P<0.005$. 
compared to the high fiber diet (Figure 3). Cytochrome P450 3A activity showed a tendency $(P=0.09)$ for a $34 \%$ lower enzyme activity in cows consuming the high cornstarch diet compared to the high fiber diet (Figure 3). The fractional rate constant of progesterone decay was not significantly different (Figure 4) between the two diets; however, the half-life of progesterone tended to be increased $(P=0.08$; Figure 4$)$ in cows consuming the high cornstarch versus the high fiber diet and averaged 85 versus 64 min, respectively. Cytochrome P450 2C mRNA expression tended $(P=0.09)$ to be decreased by $21 \%$ in cows fed the high cornstarch diet $(0.89 \pm 0.09)$ versus the high fiber diet $(1.12$ $\pm 0.09)$. Cytochrome P450 3A mRNA expression was not different between the two experimental diets.

Correlation analysis revealed a positive association of CYP2C activity with both DMI and milk yield (Table 3). Cytochrome P450 3A activity was positively correlated with both EB and DMI, while CYP3A mRNA expression was negatively correlated with EB and DMI. There was a tendency for CYP2C activity to be positively correlated with CYP3A activity.

\section{Discussion}

The current study, in lactating dairy cows, reveals a role for added dietary starch in decreasing progesterone clearance without affecting lactational performance. Pereira et al. (1999) found an increase in DMI, milk yield, milk fat yield and milk fat percentage when replacing dry, cracked corn with different nonforage fiber sources. In the current experiment cows received a diet containing $15.1 \%$ refined cornstarch (DM basis), which decreased milk fat yield and tended to increase milk protein yield compared to a high fiber diet (containing $23.1 \%$ soy bean hulls). The increase in milk protein percentage in 


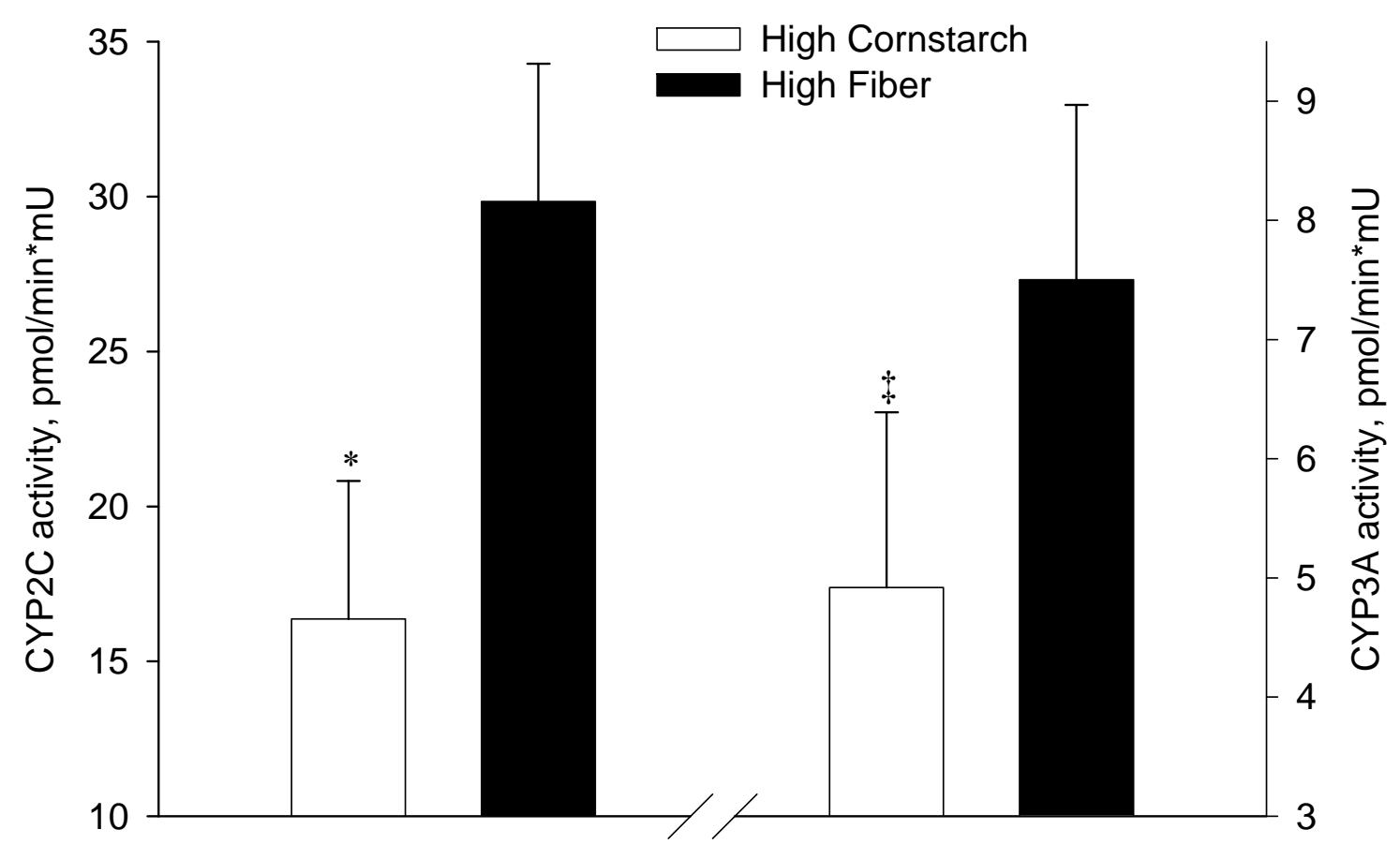

Figure 3. Hepatic CYP2C (left two bars) and CYP3A (right two bars) activity for cows consuming a high cornstarch diet (open bars) or a high fiber diet (closed bars). Asterisk indicates $P<0.05$ and double dagger indicates $P=0.09$. 


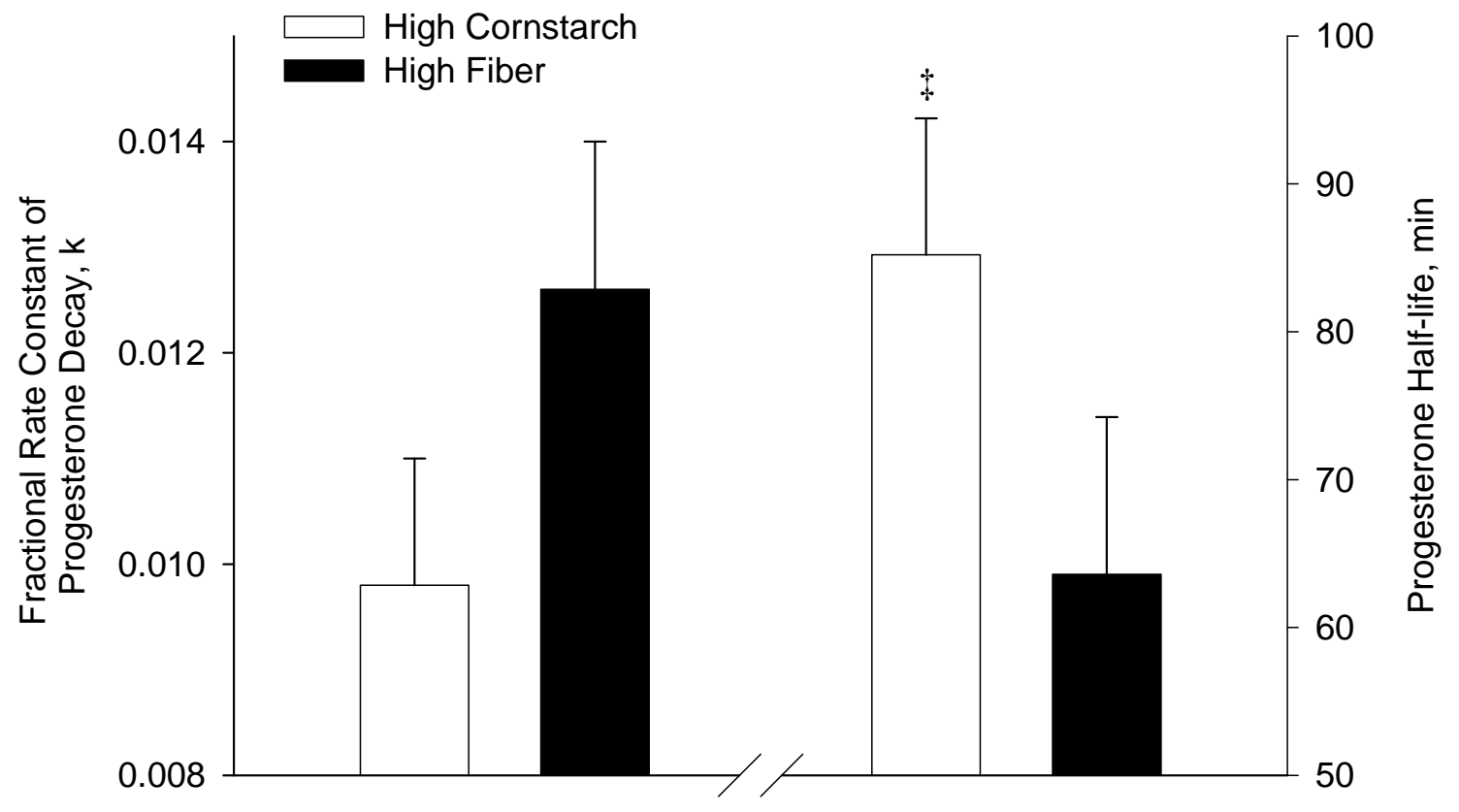

Figure 4. Fractional rate constant of progesterone decay (k; left two bars) and average half-life of progesterone ( $\mathrm{T}_{1 / 2}$; right two bars) in cows consuming a high cornstarch diet (open bars) or a high fiber diet (closed bars). The equation $T_{1 / 2}=\ln (2) / \mathrm{k}$ was used to calculate the half-life of progesterone. Double dagger indicates $P=0.08$. 
Table 3. Pearson correlation coefficients (r) for energy balance (EB), dry matter intake (DMI), milk yield (MY), insulin concentrations (Insulin), progesterone half-life (Halflife), CYP2C activity (2C Act), CYP3A activity (3A Act), CYP2C mRNA expression (2C mRNA) and CYP3A mRNA expression (3A mRNA) ${ }^{1}$

\begin{tabular}{|c|c|c|c|c|c|c|}
\hline & Insulin $^{2}$ & Half-life & 2C Act & 3A Act & 2C mRNA & 3A mRNA \\
\hline \multirow[t]{2}{*}{ EB } & 0.25 & 0.32 & 0.06 & 0.36 & 0.04 & -0.35 \\
\hline & $(0.11)$ & $(0.16)$ & $(0.71)$ & $(0.02)$ & $(0.80)$ & $(0.02)$ \\
\hline \multirow[t]{2}{*}{ DMI } & 0.14 & 0.32 & 0.38 & 0.35 & 0.14 & -0.43 \\
\hline & $(0.38)$ & $(0.17)$ & $(0.01)$ & $(0.02)$ & $(0.35)$ & $(0.003)$ \\
\hline \multirow[t]{2}{*}{ MY } & 0.03 & 0.03 & 0.30 & 0.04 & 0.04 & -0.25 \\
\hline & $(0.85)$ & $(0.90)$ & $(0.05)$ & $(0.78)$ & $(0.81)$ & $(0.11)$ \\
\hline \multirow[t]{2}{*}{ Insulin $^{2}$} & & 0.31 & -0.15 & -0.12 & -0.15 & -0.09 \\
\hline & & $(0.17)$ & $(0.33)$ & $(0.45)$ & $(0.32)$ & $(0.57)$ \\
\hline \multirow[t]{2}{*}{ Half-life } & & & -0.08 & 0.33 & -0.07 & -0.12 \\
\hline & & & $(0.73)$ & $(0.16)$ & $(0.76)$ & $(0.40)$ \\
\hline \multirow[t]{2}{*}{ 2C Act } & & & & 0.26 & 0.10 & -0.23 \\
\hline & & & & $(0.10)$ & $(0.50)$ & $(0.14)$ \\
\hline \multirow[t]{2}{*}{ 3A Act } & & & & & 0.25 & -0.10 \\
\hline & & & & & $(0.10)$ & $(0.52)$ \\
\hline \multirow[t]{2}{*}{ 2C mRNA } & & & & & & 0.60 \\
\hline & & & & & & $(<0.001)$ \\
\hline
\end{tabular}

${ }^{1} P$-values are shown in parentheses.

${ }^{2}$ Insulin concentrations at the time of liver biopsy (d 12) versus EB, DMI, MY, 2C Act, $3 \mathrm{~A}$ Act, $2 \mathrm{C}$ mRNA and $3 \mathrm{~A}$ mRNA. Insulin concentrations on $\mathrm{d} 14$ at $3 \mathrm{~h}$ post-feeding were analyzed against progesterone half-life. 
the current study may be due to an increase in starch digestion in the lower gut or increased propionate production, which could cause sparing of amino acids. Several researchers have found that replacing corn with soybean hulls increases the ratio of ruminal acetate to propionate with propionate concentration either decreasing (Sarwar et al., 1992; Cunningham et al., 1993) or remaining constant (Sievert and Shaver, 1993; Mansfield and Stern, 1994). Providing 15.1\% refined cornstarch, in the current experiment, caused a $20 \%$ increase in insulin area under the curve, which would be expected after increasing propionate availability for hepatic gluconeogenesis.

Garnsworthy et al. (2008a) altered energy source in isoenergetic and isonitrogenous dairy rations (5 dietary levels of starch; 9, 14, 16, 18 and 23\% starch). They reported increasing insulin concentrations in cows fed starch from 9 to $16 \%$ in the form of wheat; however, the postovulatory rise in progesterone was delayed in cows fed the highest starch containing diet ( $23 \%$ starch) even though insulin concentrations $(\sim 0.07$ $\mathrm{n} M$ ) had already reached a plateau at $16 \%$ dietary starch. Their second highest level of starch was below the dietary treatments fed in the current study (35 versus 19\% starch), where we found a $44 \%$ increase in insulin concentrations at the time of liver biopsy $(0.16$ versus $0.08 \mathrm{n} M$ ), which might be explained by the differences in the type of carbohydrate provided (wheat versus refined cornstarch) or the level of feed intake. Gong et al. (2002) found that high insulin diets increased the percentage of cows ovulating by d 50 postpartum. Garnsworthy et al. (2009) altered dietary treatments at the time of the first postpartum ovulation from a low insulin diet $(9.8 \%$ starch) to a high insulin diet $(18.2 \%$ starch), a high insulin diet to a low insulin diet, or continued feeding a low or high insulin diet throughout the experiment. Average plasma insulin concentrations were comparable 
to our high fiber diet and ranged from 0.06 to $0.09 \mathrm{n} M$ insulin in all treatment groups at approximately $10 \mathrm{wk}$ postpartum. Pregnancy rates were highest in cows fed the high insulin diet until the first postpartum ovulation and then switched to the low insulin diet during early pregnancy compared to the three other dietary variations. This may be due to the beneficial effect of insulin on early follicular development, leading to a shorter postpartum anestrus interval, and the negative effects of insulin on oocyte competence leading to higher embryonic loss (Chagas et al., 2007). However, insulin may have an embryo protective role if concentrations are high enough to alter endogenous concentrations of progesterone during early pregnancy. In beef heifers fed insulinstimulating diets, Mann et al. (2003) reported an increase in early embryonic development compared to low insulin diets; however, this result was not accompanied by any changes in plasma progesterone or insulin concentrations even though these diets were similar to the diets fed by Gong et al. (2002). Hawkins et al. (1995) found an increase in progesterone half-life in beef heifers fed a diet supplemented with 7.5\% Mega-Lac (Church and Dwight Inc., Princeton, NJ; $170 \mathrm{~min}$ ) compared to an energy control (113 min). In the current study our high fiber diet was supplemented with $1.9 \%$ Mega-Lac, which resulted in a $40 \%$ increase in fat percentage compared to the high cornstarch diet. In the Hawkins et al. (1995) study supplementation with 7.5\% Mega-Lac resulted in a $150 \%$ increase in dietary fat percentage. The lower amounts of Mega-Lac in the current study may explain the lack of a fat supplementation response in progesterone half-life compared to the high cornstarch diet. Moreover, the insulin response in beef heifers is marginal compared to dairy cows because they have not been predisposed to a severe negative energy balance and insulin is already elevated. In our current study, the 
inclusion of 1.9\% Mega-Lac in the high fiber diet may have resulted in decreased insulin concentrations contributing to the divergent secretion of insulin between the two dietary treatments. Garnsworthy et al. (2008b) found decreased insulin concentrations in dairy cows supplemented with Mega-Lac at 23 and $30 \mathrm{~g} / \mathrm{kg}$ of DM versus 0,8 and $15 \mathrm{~g} / \mathrm{kg}$ of DM while starch was held constant across dietary treatments. Progesterone concentrations from d 3 to 5 postovulation were elevated in cows supplemented with Mega-Lac at 23 and $30 \mathrm{~g} / \mathrm{kg}$ of DM, which may be due to increased production, decreased clearance of progesterone or both (Garnsworthy et al., 2008b).

Selvaraju et al. (2002) found elevated peripheral concentrations of progesterone in crossbred repeat breeding cows $(\mathrm{n}=21)$ treated with long-acting bovine insulin. Those cows showed a $46 \%$ increase in plasma insulin concentrations after injection as well as a 17 and $15 \%$ increase in plasma progesterone on $\mathrm{d} 8$ and 10 of the estrus cycle, respectively; although, pregnancy rates were not different between the insulin treated (63.6\%) and saline treated (40.0\%) groups (Selvaraju et al., 2002). These higher concentrations of progesterone may be due to a decrease in hepatic clearance brought about by elevated insulin concentrations, which is in agreement with our current findings. Miyoshi et al. (2001) reported an increase in days to first ovulation in cows $(\mathrm{n}=36)$ drenched daily with $500 \mathrm{ml}$ of propylene glycol. Cumulative plasma progesterone concentrations during the first estrus cycle in the propylene glycol (42.9 ng) and control (29.4 ng) cows were not different nor were the first service conception rates between the propylene glycol (57.1\%) and control (33.0\%) groups (Miyoshi et al., 2001). In a larger propylene glycol drenching experiment, Hidalgo et al. (2004) found a 33\% increase in insulin concentrations, a $27 \%$ increase in progesterone concentrations and a 33\% increase 
in pregnancy rates in cattle $(\mathrm{n}=286)$ drenched daily with $250 \mathrm{ml}$ of propylene glycol prior to embryo transfer. In non-lactating ovariectomized cows divided into groups of high and low plasma concentrations of insulin before feeding, Moriel et al. (2008) reported elevated plasma progesterone (CIDR) concentrations at $1 \mathrm{~h}$ post feeding in the high versus the low insulin group, which would suggest a protective role for insulin in decreasing progesterone clearance in vivo. However, these effects were reversed at $5 \mathrm{~h}$ post-feeding, where the low insulin group had the highest concentrations of progesterone (Moriel et al., 2008), which may be an indicator of progesterone clearance, progesterone absorption into the periphery or both.

In dairy cows chronically exposed to high insulin via a hyperinsulinemiceuglycemic clamp ( $96 \mathrm{~h}$ exposure) we found a decrease in both CYP2C and CYP3A mRNA expression (Lemley et al., 2008b). It is well established that chemically induced insulin-dependent diabetes enhances the expression of cytochrome P450 2E1, 2B, 3A and $4 \mathrm{~A}$ and that insulin administration to diabetic rats lowers the expression of these cytochrome P450s to basal levels (Barnnett et al., 1990). Both insulin and glucagon have been implicated in increasing or decreasing CYP3A expression and activity in rat hepatocytes (Saad et al., 1994). In these previous experiments supraphysiological concentrations of insulin or glucagon modified cytochrome P450 mRNA expression after extended exposure (24, 48 or $96 \mathrm{~h})$. Longer exposure times combined with high concentrations of hormone may be misleading because actual in vivo hepatic exposure to elevated insulin or glucagon could be as short as $2 \mathrm{~h}$ per day, which may be enough time to regulate enzyme activity post-translationally, while having little to no effect on mRNA expression (Berry and Skett, 1988). In the current experiment CYP2C mRNA expression 
tended to be lower in cows fed the high cornstarch diet while CYP3A mRNA expression was unchanged. Correlation analysis revealed no associations between CYP2C mRNA with CYP2C activity or CYP3A mRNA with CYP3A activity. Furthermore, CYP3A activity was positively correlated with EB and DMI, while CYP3A mRNA expression was negatively correlated with EB and DMI. Similar to our own results, Zangar and Novak (1998) found a 50\% decrease in CYP3A mRNA expression in hepatocytes treated with dimethyl sulfoxide for $48 \mathrm{~h}$, while both CYP3A protein expression and activity increased nearly 5 fold under the same culture conditions. These results are not surprising due to the evidence associated with specific substrates that regulate cytochrome $\mathrm{P} 450$ activity by decreasing or increasing protein turnover, which is independent of mRNA expression (Zangar and Novak, 1998).

In the current experiment we found a $20 \%$ increase in average insulin area under the curve and a $25 \%$ increase in progesterone half-life in cows consuming diets containing $15.1 \%$ refined cornstarch. Elevated endogenous concentrations of progesterone may decrease pregnancy loss during early gestation. Starbuck et al. (2004) found increased pregnancy retention to wk 7 of gestation in dairy cows that were classified during wk 5 as having high versus low concentrations of progesterone. Rhinehart et al. (2009) collected corpora lutea from pregnant (d 28 to 34) lactating dairy cows that were divided into low or high progesterone groups. A subcutaneous injection of $150 \mathrm{mg}$ of progesterone was given every $12 \mathrm{~h}$ to maintain pregnancy, and those cows that were previously classified as having high concentrations of progesterone had a greater progesterone area under the curve compared to the low progesterone group postlutectomy. Gene expression for components of the endothelin and prostaglandin systems 
were not different between the high and low progesterone groups, which may indicate a greater involvement in steroid clearance versus steroid production in regulating peripheral concentrations of progesterone in pregnant lactating dairy cows (Rhinehart et al., 2009).

\section{Conclusions}

Pregnancy loss continues to be a major economic concern to the dairy industry and alleviating pregnancy wastage would improve the efficiency of all dairy operations. Several researchers have found differences in plasma concentrations of steroids during pregnancy or the mid-luteal phase of the estrous cycle after varying dietary treatments or after treatment with different metabolic hormones (i.e. growth hormone and insulin); however, a substantial portion of these studies have failed to distinguish between differences due to steroid production, steroid clearance or a combination of both. In the current study we focused on clearance of progesterone from an exogenous source and found a trend for a longer half-life of progesterone after feeding a diet high in refined cornstarch compared to a high fiber diet. Cytochrome P450 2C activity was lower, while cytochrome P450 3A activity tended to be lower in cows consuming a high cornstarch diet versus a high fiber diet. Feeding diets that stimulate insulin secretion may modify progesterone clearance by inhibiting hepatic activity of cytochrome $\mathrm{P} 4502 \mathrm{C}$ and $3 \mathrm{~A}$. Decreasing steroid clearance during early pregnancy may lead to higher peripheral concentrations of progesterone, which could advance embryonic development during the early period of pregnancy when embryonic loss and pregnancy wastage are high. 


\section{References}

Association of Official Analytical Chemists. 1995. Official Methods of Analysis. Vol I. $15^{\text {th }}$ ed. AOAC, Arlington, Va.

Barnnett, C. R., G. G. Gibson, C. R. Wolf, P. R. Flatt, and C. Ioannides. 1990. Induction of cytochrome P450III and P450IV family proteins in streptozotocin-induced diabetes. Biochem. J. 268:765-769.

Berry, L. A. and P. Skett. 1988. The role of cyclic-AMP in the regulation of steroid metabolism in isolated rat hepatocytes. Biochem. Pharmacol. 37:2411-2416.

Butler, S. T., S. H. Pelton, and W. R. Butler. 2004. Insulin increases $17 \beta$-estradiol production by the dominant follicle of the first post-partum follicle wave in dairy cows. Reproduction. 127:537-545.

Chagas, L. M., J. J. Bass, D. Blache, C. R. Burke, J. K. Kay, D. R. Lindsay, M. C. Lucy, G. B. Martin, S. Meier, F. M. Rhodes, J. R. Roche, W. W. Thatcher, and R. Webb. 2007. Invited review: New perspectives on the roles of nutrition and metabolic priorities in the subfertility of high-producing dairy cows. J. Dairy Sci. 90:4022-4032.

Costine, B. A., E. K. Inskeep, K. P. Blemings, J. A. Flores, and M. E. Wilson. 2007. Mechanisms of reduced luteal sensitivity to prostaglandin F2alpha during maternal recognition of pregnancy in ewes. Domest. Anim. Endocrinol. 32:106121.

Cunningham, K. D., M. J. Cecava, and T. R. Johnson. 1993. Nutrient digestion, nitrogen and amino acid flows in lactating cows fed soybean hulls in place of forage or concentrate. J. Dairy Sci. 76:3523-3535.

Deriaz, R. E. 1961. Routine analysis of carbohydrates and lignin in herbage. J. Sci. Food Agri. 12:152-160.

Garnsworthy, P. C., A. Lock, G. E. Mann, K. D. Sinclair, and R. Webb. 2008a. Nutrition, metabolism, and fertility in dairy cows: 1 . dietary energy source and ovarian function. J. Dairy Sci. 91:3814-3823.

Garnsworthy, P. C., A. Lock, G. E. Mann, K. D. Sinclair, and R. Webb. 2008b. Nutrition, Metabolism, and fertility in dairy cows: 2. dietary fatty acids and ovarian function. J. Dairy Sci. 91:3824-3833.

Garnsworthy, P. C., A. A. Fouladi-Nashta, G. E. Mann, K. D. Sinclair, and R. Webb. 2009. Effect of dietary-induced changes in plasma insulin concentrations during 
the early post partum period on pregnancy rate in dairy cows. Reproduction. 137:759-768.

Gong, J. G., W. J. Lee, P. C. Grarnsworthy, and R. Weeb. 2002. Effect of dietary-induced increases in circulating insulin concentrations during the early postpartum period on reproductive function in dairy cows. Reproduction. 123:419-427.

Hawkins, D. E., K. D. Niswender, G. M. Oss, C. L. Moeller, K. G. Odde, H. R. Sawyer, and G. D. Niswender. 1995. An increase in serum lipids increases luteal lipid content and alters the disappearance rate of progesterone in cows. J. Anim. Sci. 73:541-545.

Hidalgo, C. O., E. Gomez, L. Prieto, P. Duque, F. Goyache, L. Fernandez, I. Fernandez, N. Facal, and C. Diez. 2004. Pregnancy rates and metabolic profiles in cattle treated with propylene glycol prior to embryo transfer. Theriogenology. 62:664676.

Inskeep, E. K. and R. A. Dailey. 2005. Embryonic death in cattle. Vet. Clin. Food Anim. 21:437-461.

Kijas, J. W., M. Menzies, and A. Ingham. 2006. Sequence diversity and rates of molecular evolution between sheep and cattle genes. Anim. Genet. 37:171-174.

Larson, S. F., W. R. Butler, and W. B. Currie. 2007. Pregnancy rates in lactating dairy cattle following supplementation of progesterone after artificial insemination. Anim. Reprod. Sci. 102:172-179.

Lemley, C. O., J. M. Koch, K. P. Blemings, K. M. Krause, and M. E. Wilson. 2008a. Concomitant changes in progesterone catabolic enzymes, cytochrome P450 2C and 3A, with plasma insulin concentrations in ewes supplemented with sodium acetate or sodium propionate. Animal. 2:1223-1229.

Lemley, C. O., S. T. Butler, W. R. Butler, and M. E. Wilson. 2008b. Short communication: insulin alters hepatic progesterone catabolic enzymes, cytochrome P450 2C and 3A, in dairy cows. J. Dairy Sci. 91:641-645.

Lemley, C. O., J. M. Koch, K. P. Blemings, and M. E. Wilson. 2009. Alterations in progesterone catabolic enzymes, CYP2C and CYP3A, in hepatocytes challenged with insulin and glucagon. J. Anim. Vet. Adv. 8:39-46.

Leroy, J. L. M. R., A. Van Soom, G. Opsomer, I. G. F. Goovaerts, and P. E. J. Bols. 2008. Reduced fertility in high-yielding dairy cows: Are the oocyte and embryo in danger? Part II. Reprod. Dom. Anim. 43:623-632.

Mann, G. E., M. P. Green, K. D. Sinclair, K. J. Demmers, M. D. Fray, C. G. Gutierrez, P. C. Garnsworthy, and R. Weeb. 2003. Effects of circulating progesterone and 
insulin on early embryo development in beef heifers. Anim. Reprod. Sci. 79:7179.

Mansfield, H. R. and M. D. Stern. 1994. Effects of soybean hulls and lignosulfonatetreated soybean meal on rumen fermentation in lactating dairy cows. J. Dairy Sci. 77:1070-1083.

Miyoshi, S., J. L. Pate, and D. L. Palmquist. 2001. Effects of propylene glycol drenching on energy balance, plasma glucose, plasma insulin, ovarian function and conception in dairy cows. Anim. Reprod. Sci. 68:29-43.

Moriel, P., T. S. Scatena, O. G. Sa Filho, R. F. Cooke, and J. L. M. Vasconcelos. 2008. Concentrations of progesterone and insulin in serum of nonlactating dairy cows in response to carbohydrate source and processing. J. Dairy Sci. 91:4616-4621.

National Research Council. 2001. Nutrient Requirements of Dairy Cattle. $7^{\text {th }}$ rev. ed. Natl. Acad. Press, Washington, DC.

Nelson, A. C., W. Huang, and D. E. Moody. 2001. Variables in human liver microsome preparation: Impact on the kinetics of L-alpha-acetylmethadol (LAAM) Ndemethylation and dextromethorphan O-demethylation. Drug Metab. Dispos. 29:319-325.

Parr, R. A., I. F. Davis, M. A. Miles, and T. J. Squires. 1993a. Feed intake affects metabolic clearance rate of progesterone in sheep. Res. Vet. Sci. 55:306-310.

Parr, R. A., I. F. Davis, M. A. Miles, and T. J. Squires. 1993b. Liver blood flow and metabolic clearance rate of progesterone in sheep. Res. Vet. Sci. 55:311-316.

Penning, T. M., M. E. Burczynski, J. M. Jez, C. Hung, H. Lin, H. Ma, M. Moore, N. Palackal, and K. Ratnam. 2000. Human 3 $\alpha$-hydroxysteroid dehydrogenase isoforms (AKR1C1-AKR1C4) of the aldo-keto reductase superfamily: functional plasticity and tissue distribution reveals roles in the inactivation and formation of male and female sex hormones. Biochem. J. 351:67-77.

Pereira, M. N., E. F. Garrett, G. R. Oetzel, and L. E. Armentanto. 1999. Partial replacement of forage with nonforage fiber sources in lactating cow diets. I. Performance and Health. J. Dairy Sci. 82:2716-2730.

Pruitt, K. D., T. Tatusova, and D. R. Maglott. 2007. NCBI reference sequences (RefSeq): a curated non-redundant sequence database of genomes, transcripts and proteins. Nucleic Acids Res. 35:D61-D65.

Rhinehart, J. D., M. J. Starbuck-Clemmer, J. A. Flores, R. A. Milvae, J. Yao, D. H. Poole, and E. K. Inskeep. 2009. Low peripheral progesterone and late 
embryonic/early fetal loss in suckled beef and lactating dairy cows.

Theriogenology. 71:480-490.

Roche, J. F. 2006. The effect of nutritional management of the dairy cow on reproductive efficiency. Anim. Reprod. Sci. 96:282-296.

Saad, B., H. Thomas, H. Schawalder, F. Waechter, and P. Maier. 1994. Oxygen tension, insulin and glucagon affect the preservation and induction of cytochrome P450 isoforms in cultured rat hepatocytes. Toxicol. Appl. Pharm. 126:372-379.

Sangsritavong, S., D. K. Combs, R. Sartori, L. E. Armentano, and M. C. Wiltbank. 2002. High feed intake increases liver blood flow and metabolism of progesterone and estradiol-17 $\beta$ in dairy cattle. J. Dairy Sci. 85:2831-2842.

Sarwar, M. J., J. L. Firkins, and M. L. Eastridge. 1992. Effects of varying forage and concentrate carbohydrates on nutrient digestibilities and milk production by dairy cows. J. Dairy Sci. 75:1533-1542.

Selvaraju, S., S. K. Agarwal, S. D. Karche, S. K. Srivastava, A. C. Majumdar, and U. Shanker. 2002. Fertility responses and hormonal profiles in repeat breeding cows treated with insulin. Anim. Reprod. Sci. 73:141-149.

Sheffel, C. E., B. R. Pratt, W. L. Ferrell, and E. K. Inskeep. 1982. Induced corpora lutea in the postpartum beef cow. II. Effects of treatment with progestogen and gonadotropins. J. Anim. Sci. 54:830-836.

Shimojo, N., T. Ishizaki, S. Imaoka, Y. Junae, S. Fujii, and K. Okuda. 1993. Changes in amounts of cytochrome P450 isozymes and levels of catalytic activities in hepatic and renal microsomes of rats with streptozotocin-induced diabetes. Biochem. Pharmacol. 46:621-627.

Sievert, S. J. and R. D. Shaver. 1993. Carbohydrates and Aspergillus oryzae effects on intake, digestion, and milk production by dairy cows. J. Dairy Sci. 76:245-254.

Smith, D. 1969. Removing and analyzing total nonstructural carbohydrates from plant tissue. Wisconsin Agric. Exp. Sta. Res. Rep. 41. p 1. Madison, WI.

Smith, D. L., B. M. Stinefelt, K. P. Blemings, and M. E. Wilson. 2006. Diet-induced alterations in progesterone clearance appear to be mediated by insulin signaling in hepatocytes. J. Anim. Sci. 84:1102-1109.

Sonstegard, T. S., A. V. Capuco, J. White, C. P. Van Tassell, E. E. Connor, J. Cho, R. Sultana, L. Shade, J. E. Wray, K. D. Wells, and J. Quackenbush. 2002. Analysis of bovine mammary gland EST and functional annotation of the Bos taurus gene index. Mamm. Genome. 13:373-379. 
Starbuck, M. J., R. A. Dailey, and E. K. Inskeep. 2004. Factors affecting retention of early pregnancy in dairy cattle. Anim. Reprod. Sci. 84:27-39.

Stevenson, J. S., M. A. Portaluppi, D. E. Tenhouse, A. Lloyd, D. R. Eborn, S. Kacuba, and J. M. DeJarnette. 2007. Interventions after artificial insemination: Conception rates, pregnancy survival, and ovarian responses to gonadotropin-releasing hormone, human chrionic gonadotropin, and progesterone. J. Dairy Sci. 90:331340 .

Swanson, K. S., N. R. Merchen, J. W. Erdman, Jr, J. K. Drackley, F. Orias, G. N. Douglas, and J. C. Huhn. 2000. Technical note: a technique for multiple liver biopsies in neonatal calves. J. Anim. Sci. 78:2459-2463.

Van Knegsel, A. T. M., H. van den Brand, J. Dijkstra, S. Tamminga, and B. Kemp. 2005. Effect of dietary energy source on energy balance, production, metabolic disorders and reproduction in lactating dairy cattle. Reprod. Nutr. Dev. 45:665688.

You, L., 2004. Steroid hormone biotransformation and xenobiotic induction of hepatic steroid metabolizing enzymes. Chem-Biol. Interact. 147:233-246.

Zangar, R. C. and R. F. Novak. 1998. Posttranslational elevation of cytochrome P450 3A levels and activity by dimethyl sulfoxide. Arch. Biochem. Biophy. 353:1-9. 


\section{DIET-INDUCED ALTERATIONS IN HEPATIC PROGESTERONE \\ CATABOLIC ENZYME ACTIVITY AND PROGESTERONE CLEARANCE RATE IN LACTATING DAIRY COWS \\ C. O. Lemley ${ }^{1}$, K. A. Vonnahme ${ }^{2}$, L. R. Tager $^{1}$, K. M. Krause ${ }^{1}$ and M. E. Wilson ${ }^{1}$ \\ ${ }^{1}$ Division of Animal and Nutritional Sciences, Davis College of Agriculture, Natural \\ Resources and Design, West Virginia University, Morgantown, WV, USA \\ ${ }^{2}$ Center for Nutrition and Pregnancy, Department of Animal Sciences, North Dakota State University, Fargo, ND, USA}

A paper published in the Journal of Endocrinology ${ }^{3}$

(Correspondence should be addressed to M. E. Wilson; Email: mwilso25@wvu.edu)

${ }^{3}$ Reprinted with permission of the Society for Endocrinology from the Journal of Endocrinology, first published March 11, 2010 as doi:10.1677/JOE-10-0042.

Keywords. progesterone clearance, insulin, dairy cow, cytochrome P450, aldo-keto reductase 


\begin{abstract}
Elevated rates of steroid clearance may lead to lower reproductive success in several mammalian species. Cytochrome P450 (EC 1.14.14.1) and aldo-keto reductases (EC 1.1.1.145-151) are involved in the first phase of steroid inactivation, before second phase conjugation and excretion of the steroid metabolite. The current objectives were to determine liver blood flow, hepatic enzyme activity and metabolic clearance rate of progesterone in dairy cows consuming isoenergetic and isonitrogenous diets formulated to cause divergent insulin secretion. Insulin concentrations increased by $22 \%$ in cows fed the high cornstarch diet, and both cytochrome P450 2C (CYP2C) and cytochrome P450 3A (CYP3A) activities were decreased $(P<0.05)$ by approximately $50 \%$, while aldo-keto reductase $1 \mathrm{C}(\mathrm{AKR} 1 \mathrm{C})$ tended $(P<0.10)$ to be lower in cows fed the high cornstarch diet. Liver blood flow was similar between the two diets (1891 \pm 91 1/h). Metabolic clearance rate $(\mathrm{MCR})$ of progesterone tended $(P<0.10)$ to be lower in cows fed the high cornstarch diet $\left(25 \pm 51 / \mathrm{h}^{*} \mathrm{BW}^{0.75}\right)$ versus the high fiber $\operatorname{diet}\left(40 \pm 6 \mathrm{l} / \mathrm{h}^{*} \mathrm{BW}^{0.75}\right)$. The half-life of progesterone was increased $(P<0.05)$ in cows fed the high cornstarch diet $(73$ $\pm 10 \mathrm{~min})$ versus the high fiber diet $(24 \pm 10 \mathrm{~min})$. In summary, cows with elevated insulin concentrations and lower enzyme activity showed a decrease in progesterone clearance without any changes in liver blood flow. This dietary relationship with hepatic enzyme activity may explain some of the observed alterations in steroid profiles during the estrous cycle or gestation of the high producing dairy cow.
\end{abstract}




\section{Introduction}

Progesterone is needed to maintain a successful pregnancy and removal of the corpus luteum will lead to termination of pregnancy unless exogenous progesterone is provided (McDonald et al. 1952, Csapo 1956). Progesterone can influence uterine secretion of nutrients and growth factors that are essential for early embryonic development and progesterone supplementation during early gestation, from several independent reports, improves pregnancy rates in dairy cows (reviewed by Mann \& Lamming 1999). Rhinehart et al. (2009) indicated a greater involvement in steroid clearance versus steroid production in regulating peripheral concentrations of progesterone in pregnant lactating dairy cows. Selection for milk production over the last 6 decades has been accompanied with a decrease in reproductive performance, which might be explained by increased metabolic stress and high-energy demands. Independent reports have found a positive association between dry matter intake (DMI), liver blood flow and the MCR of progesterone (Parr et al. 1993a, Sangsritavong et al. 2002). Elevated steroid concentrations after improving energy balance or treatment with insulin has been attributed to increased steroid production, while a paucity of in vivo studies have addressed endogenous regulators or diet-induced modifications of the enzymes responsible for progesterone inactivation.

Progesterone is inactivated in the liver by the addition of hydroxyl groups to the steroid nucleus producing a 21-hydroxyprogesterone or $6 \beta$-hydroxyprogesterone metabolite via CYP2C or CYP3A, respectively (Murray 1991, 1992). In addition, several authors have observed contributions of the AKR1C subfamily ( $3 \alpha$-hydroxysteroid dehydrogenase and 20a-hydroxyseteroid dehydrogenase activity) to progesterone 
inactivation (Penning et al. 2000). Saad et al. (1994) found a 40\% decrease in the formation of $6 \beta$-hydroxytestosterone (primarily CYP3A activity) in rat hepatocytes exposed to $10 \mathrm{nM}$ insulin versus $1 \mathrm{nM}$ insulin. Smith et al. (2006) found a dosedependent decrease in the fractional rate constant of progesterone decay in a murine hepatocyte cell-line challenged with increasing physiological concentrations of insulin. Utilizing the same cell-line and experimental conditions, Lemley et al. (2009) reported a dose-dependent decrease in the activities of both CYP2C and CYP3A after challenging hepatocytes with increasing physiological concentrations of insulin. Similar to the in vitro data, Smith et al. (2006) found a decrease in progesterone clearance in anestrous ewes orally gavaged with sodium propionate (gluconeogenic substrate) versus sodium acetate (energy control group). In a follow up experiment, Lemley et al. (2008a) found approximately a 50\% decrease in both hepatic CYP2C and CYP3A activity at 1 hour post-feeding in ovariectomized ewes supplemented with sodium propionate versus sodium acetate.

These previous results in sheep were the first evidence linking elevated insulin concentrations with lowered activity of the enzymes responsible for first phase progesterone biotransformation in vivo. We are currently extending these observations to the lactating dairy cow, which has high energy demands that lead to high rates of hepatic progesterone inactivation (Sangsritavong et al. 2002); moreover, alterations of steroid clearance in vivo have been limited to induction of mixed function monooxygenases using phenobarbital (Thomford \& Dziuk 1986). We are unaware of any experiments modifying hepatic progesterone metabolizing enzyme activity and progesterone clearance through variations in dietary energy sources. Current understanding of the relative 
contributions of first phase mixed function monooxygenase (cytochrome P450s) or oxidoreductase (aldo-keto reductases) activities in modulating peripheral concentrations of progesterone are limited to studies that rely on physiological parameters that are irreproducible in vivo. This study describes a role for modifying progesterone clearance by altering the type of dietary energy provided while maintaining adequate nutrition for gestation. The current objectives were to determine liver blood flow, cytochrome P450 and aldo-keto reducatase activity, and MCR of progesterone in dairy cows consuming isoenergetic and isonitrogenous diets formulated to cause divergent insulin secretion.

\section{Materials and Methods}

\section{Animals and feeding}

All experimental procedures were approved by the North Dakota State University Institutional Animal Care and Use Committee \#A0913. Eleven Holstein dairy cows (3 primiparous and 8 multiparous) were housed in tie stalls at the North Dakota State University dairy research barn (Fargo, ND, USA) in the Fall of 2008. Cows were randomly assigned to a high cornstarch diet or an isoenergetic and isonitrogenous high fiber diet (Table 4) in a crossover experimental design containing two 14 day periods, with 10 days of diet acclimation and the remaining 4 days used for sampling (Figure 5). Diets prior to the start of the experiment were different from both experimental diets but contained the same forages (corn silage and chopped alfalfa hay) provided in a total mixed ration. Cows were $63 \pm 4$ days in milk and were milked twice daily at 0400 and 1600 hours. Cows were provided each diet as a total mixed ration directly after each milking, approximately $40 \%$ of the feed at $0400 \mathrm{~h}$ and $60 \%$ of the feed at $1600 \mathrm{~h}$. Dry 
Table 4. Experimental diet composition and average ( \pm SEM) nutrient composition for high cornstarch $(n=4)$ or high fiber $\operatorname{diet}(n=4)$.

\begin{tabular}{lll}
\hline & High & High \\
Diet Composition & Cornstarch & Fiber \\
\hline Ingredient, \% of DM & 31.1 & 36.7 \\
Corn silage & 17.8 & 15.3 \\
Chopped alfalfa hay & 12.5 & 6.1 \\
Ground corn & 1.8 & 1.5 \\
Corn gluten meal & 5.4 & 5.1 \\
Corn gluten feed & 7.3 & 5.2 \\
Wheat middlings & 8.5 & 5.0 \\
Soybean meal (47\% CP) & - & 23.1 \\
Soybean hulls & 15.1 & - \\
Refined cornstarch & - & 1.9 \\
Mega-Lac (Ca-soaps of fatty acids) & 0.29 & 0.08 \\
Di-calcium phosphate & 0.1 & - \\
Limestone & 0.04 & 0.04 \\
Magnesium oxide & 0.13 & 0.13 \\
Trace mineral salt & 0.08 & 0.08 \\
Vitamin premix & & \\
Nutrient composition, \% of DM & $14.7 \pm 0.5$ & $14.9 \pm 0.4$ \\
NDF & $2.3 \pm 0.1$ & $2.9 \pm 0.2$ \\
ADF & 1.58 & 1.58 \\
NFC ${ }^{2}$ & & \\
Starch & $28.4 \pm 1.1$ & $39.9 \pm 0.7$ \\
CP & 50.7 & $26.0 \pm 0.4$ \\
Ether extract & $33.8 \pm 1.5$ & $19.1 \pm 0.6$ \\
Energy content, NEl Mcal/kg DM ${ }^{2}$ & & \\
& & \\
\hline
\end{tabular}

${ }^{1}$ Vitamin ADE premix (North American Nutrition Companies, Inc, Brookville, OH); Vitamin A, 9920.9 IU/g; Vitamin $\mathrm{D}_{3}$, $2204.6 \mathrm{IU} / \mathrm{g}$, Vitamin E, $4.4 \mathrm{IU} / \mathrm{g}$

${ }^{2}$ Based on tabular values (NRC, 2001)

Abbreviations; DM, dry matter; $\mathrm{CP}$, crude protein; NDF, neutral detergent fiber; ADF, acid detergent fiber; NFC, non-fiber carbohydrates; NEl, net energy used for lactation. 
Twice daily collection of milk samples and feed $10 \mathrm{~d}$ of diet adaptation samples on $\mathrm{d} 11,12,13$ and 14

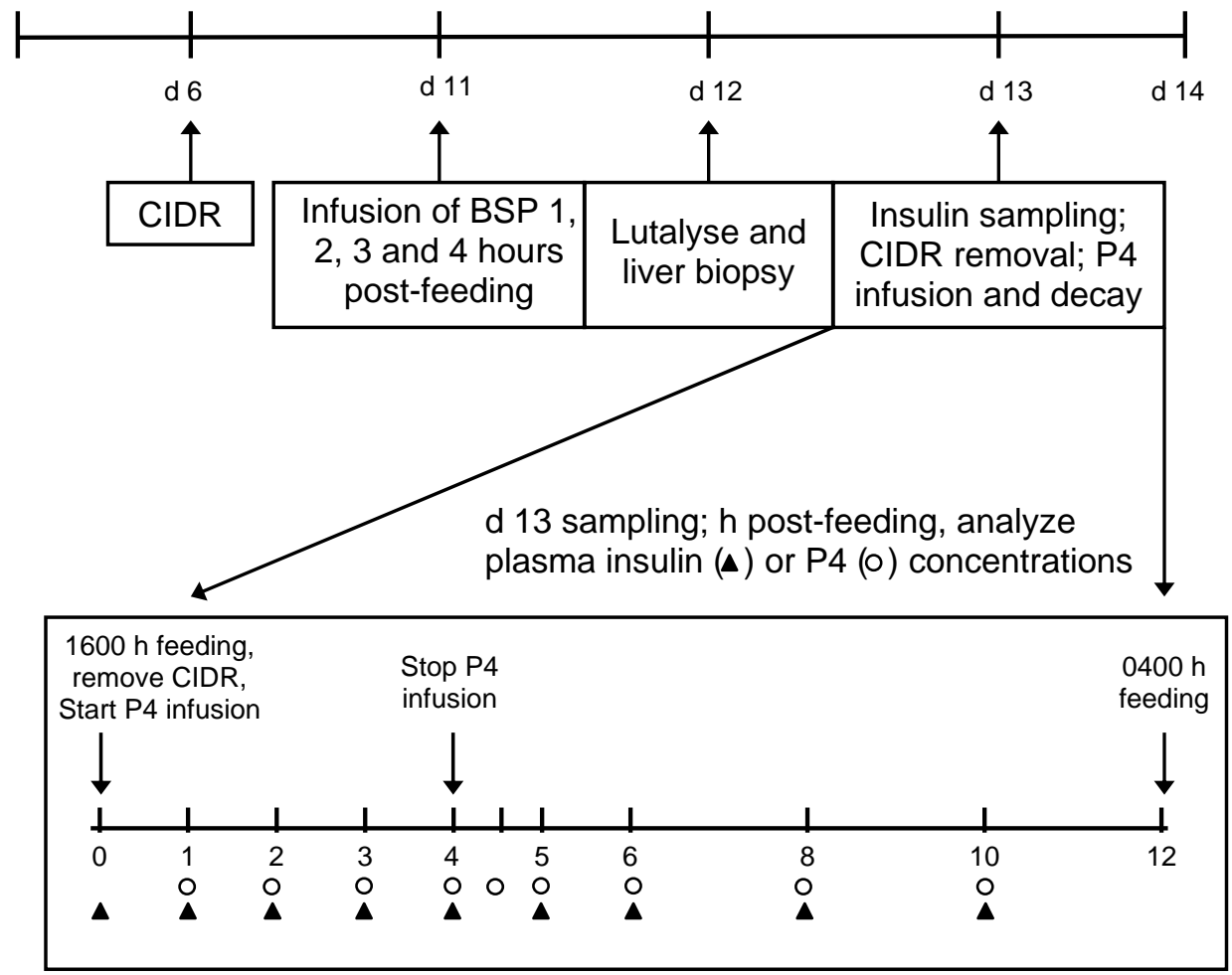

Figure 5. The crossover experimental design consisted of two identical 14 day periods that ran consecutively to one another. On day 11 cows were infused with BSP to estimate liver blood flow at hours 1, 2, 3 and 4 post-feeding. On day 12 cows were injected with Lutalyse before the $1600 \mathrm{~h}$ milking and a liver biopsy was taken $3.77 \pm 0.09$ hours post-feeding. On day 13 plasma samples were taken to determine insulin (closed triangles) and progesterone (P4; open circles) concentrations. CIDRs were removed after the start of P4 infusion, 0 hour post-feeding. MCR of $\mathrm{P} 4$ was determined at hours 1, 2, 3 and 4 post-feeding and P4 decay was determined at the end of infusion, hours $4,4.5,5,6$, 8 and 10 post-feeding. 
matter intake was kept constant for each cow across treatments in order to avoid confounding effects of DMI with differences due to dietary treatment. The feed allocated to each cow was based on her voluntary intake during the first 5 days of the experiment. On day 6 cows received a CIDR (Pfizer Inc., New York, NY, USA) containing $1.38 \mathrm{~g}$ of progesterone, which was removed at the start of the progesterone infusion experiment. After removal of CIDRs between periods 1 and 2 cows were monitored twice daily for estrous behavior and all cows used in the present study were determined to be cycling. On day 11 , at $0800 \mathrm{~h}$ both jugular veins were catheterized with Tygon tubing (Thermo Fisher Scientifics, Waltham, MA, USA; $1.02 \mathrm{~mm}$ i.d. and $1.78 \mathrm{~mm}$ o.d.) and kept patent for the next 3 days by flushing with $10 \mathrm{U} / \mathrm{ml}$ heparin (Columbus Serum Co., Columbus, $\mathrm{OH}$, USA). On day 12, cows were administered $25 \mathrm{mg}$ of lutalyse (Pfizer Inc; to remove endogenous progesterone, corpus luteum, before progesterone infusions) prior to the 1600 hour milking, and liver biopsies were taken $3.77 \pm 0.09$ hours post-feeding $(1600 \mathrm{~h}$ feeding). A portion of the liver tissue was immersed in potassium phosphate buffer and immediately used to determine CYP2C and CYP3A activity. The remaining liver sample was snap-frozen in liquid nitrogen and used for determining AKR1C activity, CYP2C mRNA and $C Y P 3 A$ mRNA expression. Milk production was recorded and milk samples were collected at each milking on day 11,12, 13 and 14, and samples were analyzed for lactose, protein and fat percent (Dairy One, Inc., Ithaca, NY, USA). Average BW (626 \pm $12 \mathrm{~kg}$ ) was determined by weighing cows before milking, after milking and halfway between milkings on day 11, 12 and 13 of each period, respectively. Feed intake, milk composition and body weight were used to estimate energy balance (EB) over the four day sampling period using the equation, $\mathrm{EB}=\mathrm{NEc}-(\mathrm{NEl}+\mathrm{NEr})$, where $\mathrm{NEc}=1.58$ 
$\mathrm{Mcal} / \mathrm{kg} * \mathrm{DMI}, \mathrm{NEl}=\mathrm{MY} *((0.0929 * \%$ fat $)+(0.0563 * \%$ protein $)+(0.0395 * \%$ lactose $))$,

$\mathrm{NEr}=\left(\mathrm{BW}^{0.75}\right)^{*} 0.08(\mathrm{NEc}$, net energy consumed; NEl, net energy used for lactation;

NEr, net energy required; NRC, 2001).

\section{Liver blood flow, MCR of progesterone and insulin concentrations}

On day 11 , directly after the $1600 \mathrm{~h}$ milking, cows were infused with $7.5 \mathrm{mg} / \mathrm{ml}$ bromosulphthalein (BSP) at an average infusion rate of $2.77 \pm 0.07 \mathrm{ml} / \mathrm{min}$. A stock solution of BSP $(20 \mathrm{mg} / \mathrm{ml})$ was diluted to $7.5 \mathrm{mg} / \mathrm{ml}$ in 11 saline bags. Saline bags were attached to an i.v. system containing a $100 \mathrm{ml}$ burette (Columbus Serum Co.), which allowed for calculations of flow rates that were estimated every half hour. The i.v. systems for each cow were attached to a 12 channel peristaltic pump (Masterflex, ColeParmer, Vernon Hills, IL) containing silicone tubing with a $2.79 \mathrm{~mm}$ i.d. allowing for a maximal flow rate of $4 \mathrm{~mL} / \mathrm{min}$. Catheters and tubing were gas sterilized prior to use with Anprolene gas ampules (Andersen Products Inc., Haw River, NC, USA) and all catheter lines were flushed with $70 \%$ ethanol before and after infusions. Jugular blood samples were collected into pre-chilled EDTA containing tubes at 1,2,3, and 4 hours post-feeding. BSP concentrations in plasma were determined using the methods from Sangsritavong et al. (2002). Briefly, $50 \mu \mathrm{l}$ of plasma was mixed with $150 \mu \mathrm{l}$ of $0.5 \mathrm{~N}$ ammonium hydroxide (Sigma Chemical Co., St. Louis, MO, USA) and absorbance was determined at wavelengths 580 and $426 \mathrm{~nm}$ on a Spectra Max Plus plate reader (Molecular Devices, Inc., Sunnyvale, CA, USA). BSP concentrations were corrected for any hemolysis in the plasma using the equation, BSP concentrations $=[($ absorbance at $580 \mathrm{~nm})-(0.2 *$ absorbance at $426 \mathrm{~nm})]-\mathrm{A}$. The value $\mathrm{A}=$ absorbance at $580 \mathrm{~nm}$ 
before BSP infusion $-(0.2 *$ absorbance at $426 \mathrm{~nm})$. The constant 0.2 was determined by hemolyzing blood samples and comparing their absorbance at 580 and $426 \mathrm{~nm}$ after the addition of $0.5 \mathrm{~N}$ ammonium hydroxide. A standard curve of BSP ( 0 to $50 \mu \mathrm{g} / \mathrm{ml})$ in cow plasma was used to calculate peripheral concentrations. The MCR of BSP was calculated using the equation, MCR of BSP $(1 / h)=$ infusion rate $(\mu \mathrm{g} / \mathrm{h}) / \mathrm{BSP}$ concentration in plasma $(\mu \mathrm{g} / \mathrm{l})$. Liver blood flow $(\mathrm{LBF})$ was calculated using the equation, $\operatorname{LBF}(1 / \mathrm{h})=$ MCR of BSP $(1 / h) / 0.8 *(1-$ hematocrit fraction $)$.

On day 13 , directly after the $1600 \mathrm{~h}$ milking, cows were infused with $50 \mu \mathrm{g} / \mathrm{ml}$ progesterone at an average infusion rate of $2.45 \pm 0.09 \mathrm{ml} / \mathrm{min}$. A stock solution of 1 $\mathrm{mg} / \mathrm{ml}$ progesterone in ethanol was diluted into 11 saline bags to a final concentration of $50 \mu \mathrm{g} / \mathrm{ml}$. Infusion procedures were similar to the BSP infusions, except that CIDRs were withdrawn 10 min after the start of infusions (approximately 5 min before feeding) to assure tissue saturation with progesterone. Steady state concentrations of progesterone were reached within 1 hour of infusions, which were determined during a preliminary experiment at the West Virginia University Animal Sciences Farm, Morgantown, WV, USA. A jugular plasma sample was collected at hours $0,1,2,3$, and 4 hours postfeeding. The MCR of progesterone was calculated using the equation, MCR of progesterone $(1 / \mathrm{h})=$ infusion rate $(\mu \mathrm{g} / \mathrm{h}) /$ progesterone concentration in plasma $(\mu \mathrm{g} / \mathrm{l}) /$ 0.6 (Sangsritavong et al. 2002). After completion of the $4 \mathrm{~h}$ progesterone infusion, blood samples were collected at $\mathrm{h} 4.5,5,6,8$, and 10 post-feeding. These samples were used to determine the fractional rate constants of progesterone decay $(\mathrm{k})$. Briefly, $\mathrm{k}$ were calculated for each individual cow with SigmaPlot 8.0 (Aspire Software International, Ashburn, VA, USA) using the equation $\mathrm{P}_{\mathrm{t}}=\mathrm{P}_{\mathrm{o}} \mathrm{e}^{-\mathrm{kt}}$ ( $\mathrm{Pt}$, progesterone concentrations at any 
given time; Po, initial progesterone concentrations; t, time) as described by Lemley et al. (2008a). The fractional rate constants of progesterone decay $(\mathrm{k})$ were then used to calculate the half-life of progesterone using the equation, $t_{1 / 2}=\ln (2) / k$. Progesterone concentrations were determined using RIA (Sheffel et al. 1982) with a sensitivity of 100 $\mathrm{pg} / \mathrm{ml}$ and intra- and inter-assay CV of 4.3 and $6.7 \%$, respectively. Briefly, the progesterone standard curve ranged from 0.1 to $4 \mathrm{ng} / \mathrm{ml}$. One-hundred $\mu \mathrm{l}$ of plasma was extracted with $3 \mathrm{ml}$ of petroleum ether and separated from the aqueous phase by freezing with dry ice in 2-propanol. Dextran coated charcoal was used to separate free and bound ligand. The antibody for the progesterone assay was previously characterized by Butcher (1977). The only cross reactions of the 18 steroids tested were: pregnenolone, $15 \%$; $5 \alpha$ pregnane-3,20-dione, 15\%; 17 $\alpha$-hydroxy-4-pregnene-3,20-dione, $3 \%$; testosterone, $2 \%$;

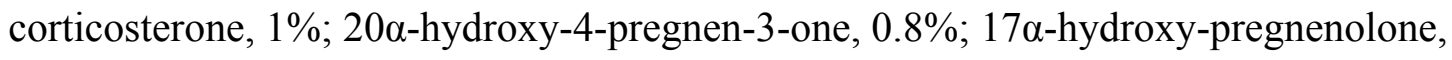
0.6\% (Butcher 1977). Insulin concentrations over the 10 hour sampling period were determined using RIA (Lemley et al. 2008a) with a sensitivity of $0.05 \mathrm{nM}$ and intra- and inter-assay CV of 4.2 and $6.4 \%$, respectively. The assay was validated to measure bovine insulin in our laboratory. Briefly, plasma dilutions from two cows were assayed separately for insulin and found to be parallel with the standard curve. In addition, a plasma sample was spiked with bovine insulin (Sigma Chemical Co., St Louis, MO, USA) to determine percent recovery, which was greater than $90 \%$.

\section{Cellular fractionation and enzymatic activity}

On day 12 , the $1600 \mathrm{~h}$ feeding was staggered for each cow by $5 \mathrm{~min}$ to assure similar liver biopsy times post-feeding ( $3.77 \pm 0.09$ hours post-feeding). Briefly, the hair 
was removed from the animals' right side and the skin was scrubbed twice with betadine (Columbus Serum, Columbus, OH, USA). After determining the location of the tenth intercostal space, $2 \%$ lidocaine hydrochloride (Columbus Serum) was administered as a local anesthetic. The skin was punctured using a scalpel and the liver samples $(1.1 \pm 0.1$ $\mathrm{g} /$ biopsy) were collected using a biopsy needle machined at the West Virginia University Physics Department (Morgantown, WV, USA) following the specifications of Swanson et al. (2000). CYP2C and CYP3A activities were assessed on approximately $200 \mathrm{mg}$ of fresh liver sample following our previously published protocol (Lemley et al. 2008a). Briefly, liver samples were submerged in phosphate buffer and homogenized using a Dounce homogenizer. Microsomes were collected and concentrated using differential centrifugation techniques (modified from Nelson et al. 2001). Homogenized tissue was centrifuged at $10,000 \mathrm{xg}$ for $10 \mathrm{~min}$. Pellets were discarded and the supernatants were centrifuged at 100,000 $\mathrm{x}$ g for $60 \mathrm{~min}$. The microsomal pellets were resuspended in phosphate buffer and the activity of cytochrome c reductase (product number CY0100; Sigma Chemical Co.) was used to standardize CYP2C and CYP3A activity. CYP2C activity was measured as the non-ketoconazole-inhibitable, omeprazole-dependent oxidation of NADPH. Microsomes were pre-incubated for 15 min with $250 \mu \mathrm{M}$ ketoconazole. CYP2C enzymatic reactions contained CYP3A inhibited microsomes, 2.5 $\mathrm{mM}$ omeprazole and $250 \mu \mathrm{M}$ NADPH. CYP3A activity was measured as the nifedipinedependent oxidation of NADPH. CYP3A enzymatic reactions contained fresh microsomes, $200 \mu \mathrm{M}$ nifedipine and $250 \mu \mathrm{M}$ NADPH. AKR1C activity was determined in cytosolic cellular fractions using the specific substrate 1-acenapthenol following the methods of Savlik et al. (2007) and Palackal et al. (2002). Briefly, AKR1C enzymatic 
reactions contained 150 to $650 \mu \mathrm{g}$ of cytosolic protein, $250 \mu \mathrm{M} 1$-acenapthenol and 500 $\mu \mathrm{M}$ NADP. The 1-acenapthenol-dependent reduction of NADP was standardized using cytosolic protein. All solutions were added to UV star 96-well plates (PGC Scientifics, Frederick, MD) and the oxidation of NADPH or reduction of NADP was determined by measuring the amount of light absorbed at $340 \mathrm{~nm}$ for $5 \mathrm{~min}$ at $37^{\circ} \mathrm{C}$. The rate of oxidized NADPH or reduced NADP was determined to be linear over the 5 min period. The extinction coefficient for NADPH $\left(62201 / \mathrm{mol}^{*} \mathrm{~cm}\right)$ was used to calculate oxidized NADPH or reduced NADP per unit time.

\section{CYP2C and CYP3A mRNA expression}

Liver samples were stored at $-80{ }^{\circ} \mathrm{C}$ until total cellular RNA was extracted using TRIzol reagent (Invitrogen, Carlsbad, CA, USA) and precipitated with 2-propanol following the manufacturers protocol. Concentrations of RNA in each sample were determined using a Nanodrop ND-1000 spectrophotometer. One $\mu$ g of RNA was electrophoresed through a $1.5 \%$ agarose gel to determine sample purity and for visualization of $28 \mathrm{~S}$ and $18 \mathrm{~S}$ rRNA bands. Real Time RT-PCR was performed as previously described (Costine et al. 2007). Briefly, samples were diluted to $1 \mu \mathrm{g}$ RNA/ $\mu 1$ and reverse transcribed using moloney murine leukemia virus reverse transcriptase (Promega, Madison, WI, USA) following the manufacturers protocol. Beta-actin was used as a reference gene for measurements of bovine $C Y P 2 C$ and $C Y P 3 A$ genes.

(National Center for Biotechnology Information; http://www.ncbi.nlm.nih.gov/). Primers for $\beta$-actin (accession no. NM_001009784; forward: 5'-ATGAGCTGCCCGATGGTC3'; reverse: 5'-GGATGTCCACGTCACACTTC-3'), CYP2C (accession no. 
XM_587518; forward: 5'-TATGGACTCCTGCTCCTGCT-3'; reverse: 5'-

CATCTGTGTAGGGCATGCAG-3') and CYP3A (accession no. BT030557; forward: 5'-GTGCCAATCTCTGTGCTTCA-3'; reverse: 5'-CCAGTTCCAAAAGGCAGGTA3') were synthesized (Integrated DNA Technologies, Inc., Coralville, IA, USA).

Amplification was optimal at an annealing temperature of $63.1{ }^{\circ} \mathrm{C}$ and efficiencies for $\beta$ actin, CYP2C and CYP3A were 1.89, 1.95 and 1.85 (theoretical yields of 94.5, 97.5, and 92.5\%, respectively). The relative abundance of mRNA for $C Y P 2 C$ and $C Y P 3 A$ were corrected for PCR efficiency, standardized using $\beta$-actin and expressed relative to a pooled sample, as described by Costine et al. (2007).

\section{Feed Analysis}

Dry matter of diets was determined by oven drying at $60{ }^{\circ} \mathrm{C}$ for $48 \mathrm{~h}$. Ether extraction of diets was performed according to AOAC (1995) using a Soxtec Foss Tecator (Foss Analytical, Hillerød, Denmark). Ash content and organic matter was determined using the procedure described by AOAC (1995). Diets were ashed at $500{ }^{\circ} \mathrm{C}$ for $16 \mathrm{~h}$. Neutral detergent fiber and ADF content were determined using an Ankom 200 Fiber Analyzer (Ankom Technology Corp, Macedon, NY, USA). Total nitrogen and crude protein was analyzed according to AOAC (1995) using an automated Tecator digestion system (Tecator, Inc., Herndon, VA). Sugars in the diet were determined by the extraction procedure adapted from Deriaz (1961). Reducing sugars were determined spectrophotometrically with potassium ferricyanide. Starch content of the diets was

determined by the procedure of Smith (1969). 


\section{Statistical Analysis}

The effects of diet on the dependent variables were tested with the MIXED procedure of SAS (SAS software version 9.1, SAS Institute Inc., Cary, NC, USA). The model statement included period (period that dietary treatment was applied), order (order of dietary treatments), parity and diet while days in milk was used as a covariant. Cow within order was considered random and means were separated using the PDIFF option of the LSMEANS statement. MCR of progesterone and insulin concentrations were tested using repeated measures ANOVA of the MIXED procedure of SAS with an autoregressive covariance structure, and means were separated using the DIFF option of the LSMEANS statement. Pearson correlation coefficients were determined using the CORR procedure of SAS. Least square means and SEM are reported. Trends were declared at $P<0.10$ and $P>0.05$. Statistical significance was declared at $P \leq 0.05$.

\section{Results}

Dry matter intake, milk yield and milk lactose yield were similar $(P>0.50$; Table 5) between the two experimental diets. Milk fat percentage was decreased by $15 \%(P<$ $0.001)$, while milk fat yield was decreased by $14 \%(P<0.005)$ in cows consuming the high cornstarch diet versus the high fiber diet. Milk protein percentage was increased by $6 \%(P<0.01)$, while milk protein yield showed a trend $(P=0.06)$ for a $6 \%$ increase in cows consuming the high cornstarch diet versus the high fiber diet (Table 5). Energy balance was improved $(P<0.05)$ in cows consuming the high cornstarch diet compared 
Table 5. Effect of a high cornstarch diet $(n=11)$ versus a high fiber $\operatorname{diet}(n=11)$ on intake and milk production in lactating dairy cows.

\begin{tabular}{lcccr}
\hline & High & \multicolumn{1}{l}{ High } & \\
Dependent variable & Cornstarch & \multicolumn{1}{l}{ Fiber } & SEM & $P$ value \\
\hline DMI, kg/d & 24.77 & 24.44 & 0.82 & 0.516 \\
Milk yield, kg/d & 37.19 & 36.82 & 2.31 & 0.677 \\
Fat percent, \% & 3.54 & 4.14 & 0.17 & $<0.001$ \\
Fat yield, kg/d & 1.31 & 1.53 & 0.13 & 0.001 \\
Protein percent, \% & 2.91 & 2.73 & 0.05 & 0.005 \\
Protein yield, kg/d & 1.08 & 1.01 & 0.06 & 0.056 \\
Lactose percent, \% & 4.83 & 4.92 & 0.05 & 0.070 \\
Lactose yield, kg/d & 1.80 & 1.81 & 0.12 & 0.825 \\
Energy balance, Mcal/d & 4.09 & 1.94 & 1.07 & 0.028 \\
\hline
\end{tabular}


to the high fiber diet (Table 5). Effect of order was not significant for all variables measured.

Insulin response and hepatic enzyme activities are depicted in Table 6. Average insulin concentrations, over the 10 hour blood sampling period, were increased by $22 \%$ in cows consuming the high cornstarch diet versus the high fiber diet. Plasma insulin concentrations at the time of liver biopsy ( $3.77 \pm 0.09$ hours post-feeding) were not different between the two diets. CYP2C activity was decreased by $56 \%$ for cows fed the high cornstarch compared to the high fiber diet. Similarly, CYP3A activity was decreased by $54 \%$ for cows consuming the high cornstarch diet compared to the high fiber diet. AKR1C activity tended to be $19 \%$ lower in cows consuming the high cornstarch diet versus the high fiber diet. Average liver blood flow was similar between the two diets $(1891 \pm 91 \mathrm{l} / \mathrm{h} ; P>0.40)$. We observed a trend for a decrease $(P=0.06)$ in the average MCR of progesterone (Figure 6) in cows fed the high cornstarch diet versus the high fiber diet. At 1 hour post-feeding the MCR of progesterone was similar between the two diets; however, hours 2, 3 and 4 tended $(P<0.10)$ to be lower in cows consuming the high cornstarch diet compared to the high fiber diet. The fractional rate constant of progesterone decay was not significantly different $(P=0.115)$ between the two diets; however, the half-life of progesterone was lengthened $(P<0.01)$ in cows fed the high cornstarch diet $(73 \pm 10 \mathrm{~min})$ versus the high fiber diet $(24 \pm 10 \mathrm{~min}$; Figure 7$) . C Y P 2 C$ and $C Y P 3 A$ mRNA expression was not different between the two experimental diets (data not shown).

Correlation analysis revealed a positive association between EB and insulin concentrations averaged across the 10 hour blood sampling (Table 7). Energy balance 
Table 6. Average insulin concentrations over the $10 \mathrm{~h}$ blood sampling period, insulin concentrations at the time of liver biopsy (3.77 $\pm 0.09 \mathrm{~h}$ post-feeding) and hepatic CYP2C, CYP3A and AKR1C activity in cows consuming a high cornstarch diet $(\mathrm{n}=11)$ or a high fiber diet $(n=11)$.

\begin{tabular}{lcccc}
\hline & High & High & & \\
Dependent Variable & Cornstarch & Fiber & SEM & $P$ value \\
\hline Average Insulin (nM) & 0.18 & 0.14 & 0.01 & 0.048 \\
Biopsy Insulin (nM) & 0.22 & 0.17 & 0.03 & 0.198 \\
CYP2C (pmol/min*mU reductase) & 14.8 & 33.8 & 4.2 & 0.008 \\
CYP3A (pmol/min*mU reductase) & 4.24 & 9.31 & 1.41 & 0.027 \\
AKR1C (pmol/min*mg protein) & 178.9 & 221.2 & 15.2 & 0.069 \\
\hline
\end{tabular}




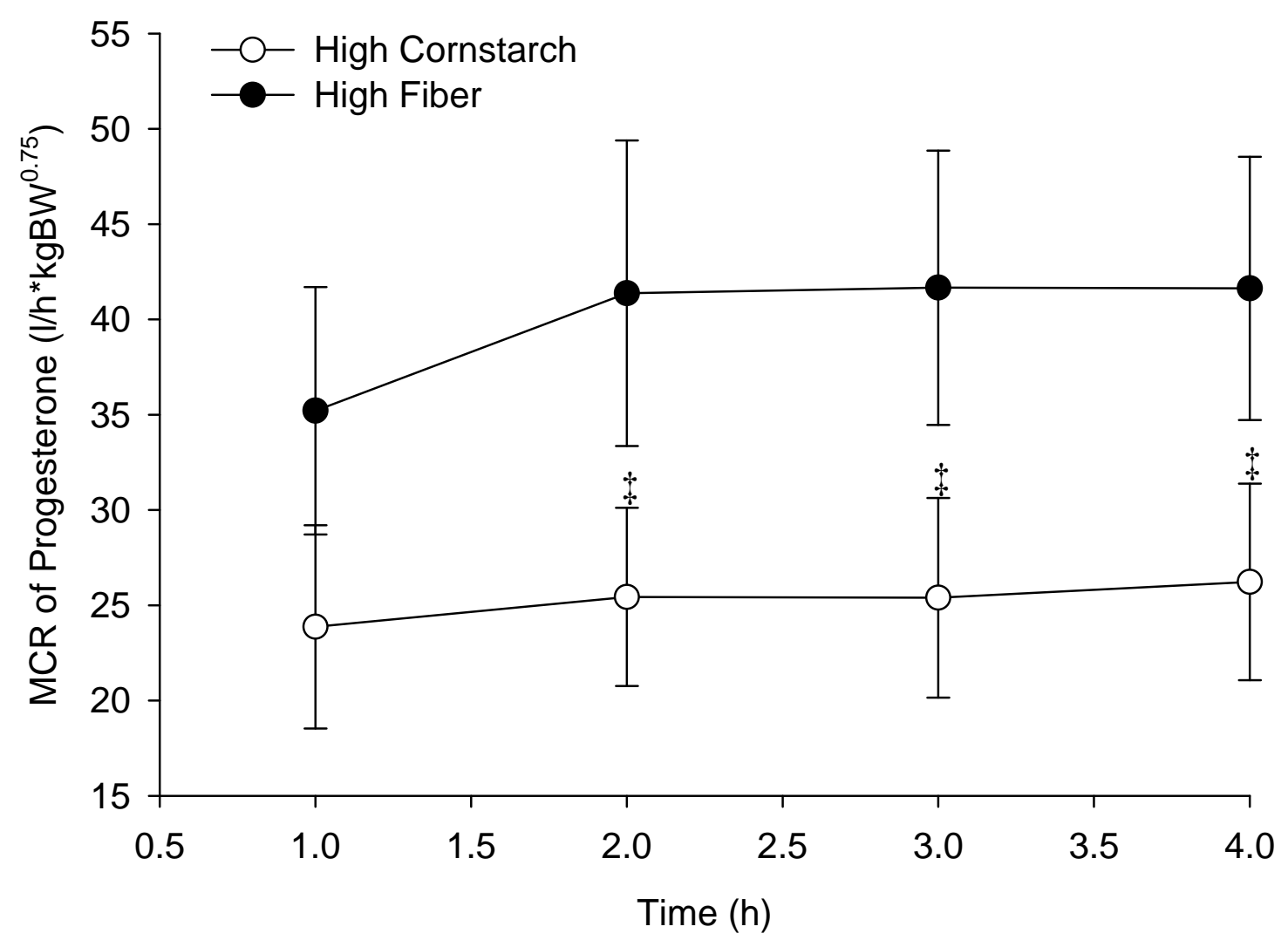

Figure 6. Metabolic clearance rate of progesterone, standardized by body weight, for cows consuming the high cornstarch diet (open circles, $\mathrm{n}=10$ ) or the high fiber diet (closed circles, $\mathrm{n}=10$ ). Effect of diet $P=0.06$, double daggers $(\ddagger)$ represent $P<0.10$. 


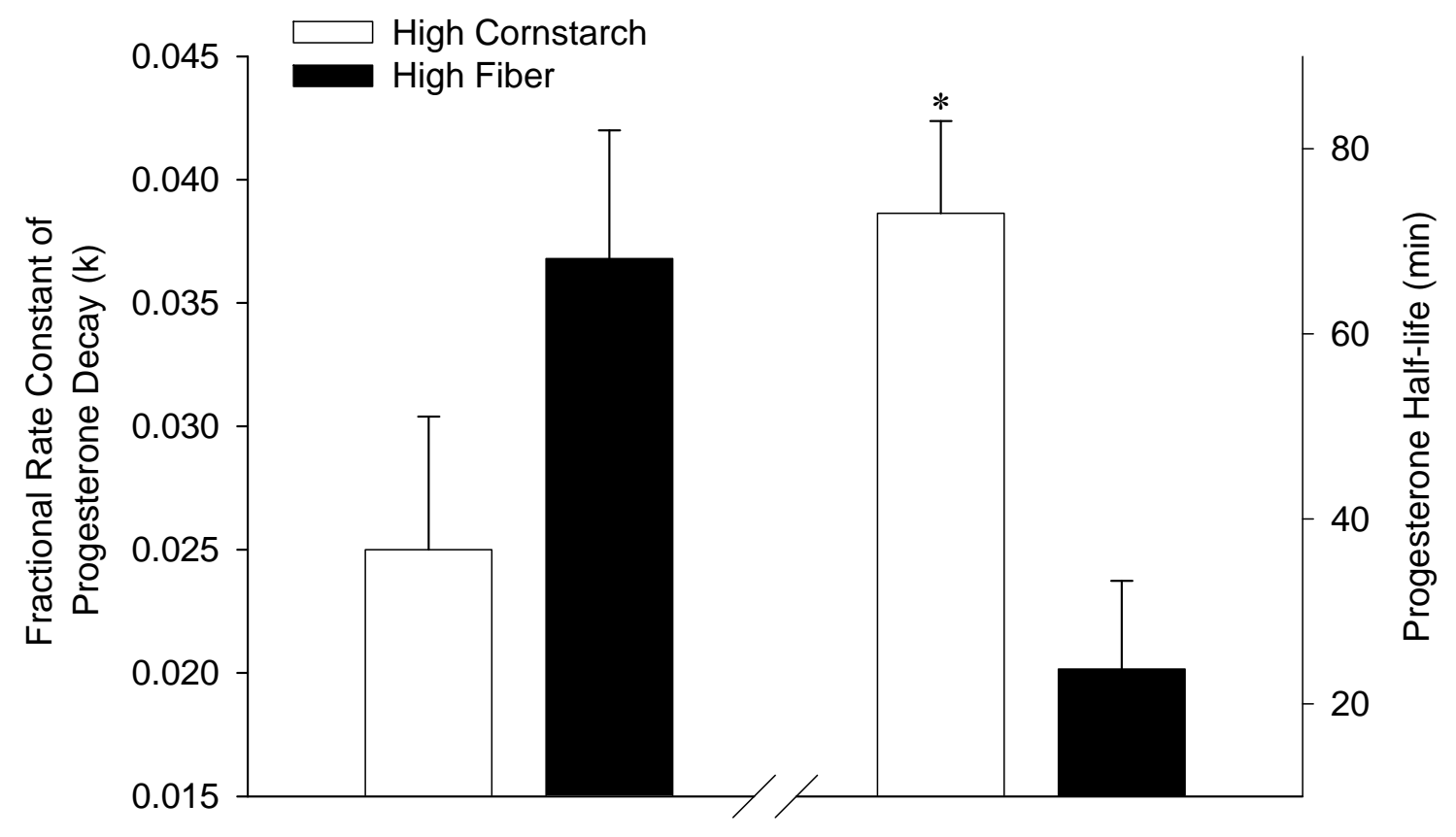

Figure 7. Fractional rate constant of progesterone decay (k; left two bars) and average half-life of progesterone ( $\mathrm{T}_{1 / 2}$; right two bars) in cows consuming a high cornstarch diet (open bars, $n=10$ ) or a high fiber diet (closed bars, $n=11$ ). The equation $T_{1 / 2}=\ln (2) / k$ was used to calculate the half-life of progesterone. Asterisk (*) represents a $P<0.01$. 
Table 7. Correlation coefficients ( $r)$ for energy balance $(E B, n=22)$, average insulin concentrations over the $10 \mathrm{~h}$ sampling period (Insulin, $\mathrm{n}=22$ ), average liver blood flow (LBF, $n=21$ ), progesterone half-life (Half-life, $n=21$ ), average metabolic clearance rate of progesterone on a body weight basis (MCR, $n=20)$, CYP2C activity ( $2 \mathrm{CAct}, \mathrm{n}=22)$, CYP3A activity ( $3 \mathrm{~A}$ Act, $\mathrm{n}=22$ ), AKR1C activity (AKR Act, $\mathrm{n}=22$ ). $P$-values are presented in parentheses.

\begin{tabular}{lccccccc}
\hline & Insulin & LBF & Half-life & MCR & 2C Act & 3A Act & AKR Act \\
\hline EB & 0.43 & 0.20 & 0.55 & -0.45 & -0.31 & -0.03 & -0.16 \\
& $\mathbf{( 0 . 0 4 )}$ & $(0.38)$ & $\mathbf{( 0 . 0 0 9 )}$ & $\mathbf{( 0 . 0 4 )}$ & $(0.16)$ & $(0.91)$ & $(0.46)$ \\
Insulin & & -0.17 & 0.47 & -0.28 & -0.59 & 0.03 & 0.10 \\
& & $(0.45)$ & $(\mathbf{0 . 0 3})$ & $(0.24)$ & $\mathbf{( 0 . 0 0 4 )}$ & $(0.88)$ & $(0.66)$ \\
LBF & & & -0.21 & -0.28 & 0.13 & -0.26 & -0.04 \\
& & & $(0.37)$ & $(0.24)$ & $(0.58)$ & $(0.26)$ & $(0.85)$ \\
Half-life & & & -0.23 & -0.51 & 0.02 & -0.04 \\
& & & & $(0.35)$ & $(\mathbf{0 . 0 2})$ & $(0.94)$ & $(0.85)$ \\
MCR & & & & 0.22 & 0.45 & 0.39 \\
& & & & & $(0.35)$ & $(\mathbf{0 . 0 5})$ & $(\mathbf{0 . 0 8})$ \\
2C Act & & & & & & -0.05 & 0.06 \\
& & & & & & $(0.82)$ & $(0.77)$ \\
3A Act & & & & & & & 0.38 \\
& & & & & & & \\
\hline
\end{tabular}


was positively correlated with the half-life of progesterone and negatively correlated with the MCR of progesterone on a per body weight basis. Average insulin was positively correlated with progesterone half-life and negatively correlated with CYP2C activity. Progesterone half-life was negatively correlated with CYP2C activity, while CYP3A activity and AKR1C activity were positively correlated with the average MCR of progesterone.

\section{Discussion}

In the current study a high cornstarch diet improved energy balance and increased peripheral insulin concentrations. Hepatic progesterone catabolic enzyme activities were decreased after feeding a high cornstarch diet and the MCR of progesterone tended to be lower while the half-life of progesterone was significantly lengthened in cows consuming a high cornstarch diet. Milk yield was not affected by dietary treatments; however, milk fat yield and milk protein yield were altered after feeding a high cornstarch diet versus a high fiber diet. Several researchers have found that replacing corn with soybean hulls increased the ratio of ruminal acetate to propionate with propionate concentration either decreasing (Sarwar et al. 1992, Cunningham et al. 1993) or remaining constant (Sievert \& Shaver 1993, Mansfield \& Stern 1994). Providing 15.1\% refined cornstarch, in the current experiment, caused a $22 \%$ increase in average concentrations of insulin sampled over a 10 hour period, which would be expected after increasing propionate availability for hepatic gluconeogenesis.

Butler et al. (2004) infused insulin at a constant rate of $0.3 \mu \mathrm{g} / \mathrm{kgBW}^{*} \mathrm{~h}$ in dairy cows during 10 to 14 days post-calving, which increased plasma insulin by 2.6 -fold and 
increased peripheral concentrations of both estradiol and testosterone compared to control cows. Although steroid production versus steroid clearance were not measured in the Butler et al. (2004) study, it is worthwhile to note that similar catabolic pathways exist between steroids and elevated insulin in this study could have affected peripheral clearance rather than production of estradiol. In early postpartum dairy cows fed a glucogenic (26.6\% starch), mixed (17.9\% starch) or lipogenic diet (10.4\% starch), Van Knegsel et al. (2007) found no difference in DMI or energy intake between dietary treatments; however, energy balance was improved in multiparous cows fed the glucogenic diet compared to the mixed diet. In the current study we found improvements in energy balance, which were presumably due to a decrease in milk fat yield and a shift in energy partitioning due to elevated insulin. Of the reproductive parameters tested in the Van Knegsel et al. (2007) study multiparous cows fed the glucogenic diet tended to have shorter days until first progesterone rise. Mean progesterone concentrations were not different between the three diets, which may be due to the addition of fat and/or the addition of citrus pulp in the lipogenic diet. Hawkins et al. (1995) found an increase in progesterone half-life in beef heifers fed a lipogenic diet $(170 \mathrm{~min})$ compared to an energy control (113 min). Whereas, citrus products contain furanocoumarins (i.e., bergamottin), strong inhibitors of cytochrome P450 enzymes (Sahi et al. 2002), which may lead to decreased progesterone clearance after supplementing animals with citrus pulp. This is in agreement with our current findings showing a decrease in cytochrome P450 activity accompanied by a decrease in progesterone clearance.

Researchers have found no change or increased first service conception rates after supplementing cows with progesterone in the form of a CIDR, which can increase 
peripheral concentrations of progesterone by approximately $1 \mathrm{ng} / \mathrm{ml}$ (Larson et al. 2007, Stevenson et al. 2007). However, supplementation with progesterone partially masks the high rates of progesterone clearance in dairy cows and fails to address the issue of excessive steroid clearance due to elevated feed intake during early lactation. Rhinehart et al. (2009) supplemented exogenous progesterone to lutectomized dairy cows that were previously classified as having high or low endogenous concentrations of progesterone. Cows that were previously classified as having high endogenous concentrations of progesterone had a greater progesterone area under the curve compared to the low progesterone group post-lutectomy. Gene expression for components of the endothelin and prostaglandin systems in corpora lutea were not different between the high and low progesterone groups, which may indicate a greater involvement in steroid clearance versus steroid production in regulating peripheral concentrations of progesterone in pregnant lactating dairy cows (Rhinehart et al. 2009).

In dairy cows chronically exposed to high insulin via a hyperinsulinemiceuglycemic clamp (96 hour exposure) we found a decrease in both CYP2C and CYP3A mRNA expression (Lemley et al. 2008b). Both insulin and glucagon have been implicated in increasing or decreasing $C Y P 3 A$ expression and activity in rat hepatocytes (Saad et al. 1994). In these previous experiments supraphysiological concentrations of insulin or glucagon modified cytochrome P450 mRNA expression after extended exposure $(24,48$, or 96 hours). In the current experiment both CYP2C and CYP3A activity were altered while $C Y P 2 C$ and $C Y P 3 A$ mRNA expression were similar between dietary treatments. These results are not surprising due to the evidence associated with specific substrates that regulate cytochrome $\mathrm{P} 450$ activity by decreasing or increasing 
protein turnover, which is independent of mRNA expression (Zangar \& Novak 1998). In the current study AKR1C activity tended to be lower in cows consuming the high cornstarch diet. AKR activity has been previously reported in pigs, cattle, goats and sheep (Szotakova et al. 2004); however this is the first study linking hepatic AKR1C activity with the MCR of progesterone in lactating dairy cows. Similar to the cytochrome P450 superfamily the AKR1C enzymes have been implicated in first phase steroid biotransformation, specifically at the $3 \alpha, 17 \beta$ and $20 \alpha$ positions of the steroid nucleus (Penning et al. 2004, Penning et al. 2001, Shimada et al. 2006) and decreased activity would be expected to increase the half-life of progesterone in peripheral circulation.

Parr et al. (1993a) found a linear decrease in progesterone concentrations as well as a linear increase in MCR of progesterone as feed intake was increased from half maintenance, maintenance and twice maintenance requirements. Parr et al. (1993b) determined that approximately $96 \%$ of the progesterone entering into the gut and liver was inactivated. This inverse relationship between plasma concentrations of progesterone and feed intake were later associated with a linear increase in liver blood flow (Parr et al. 1993b). Sangsritavong et al. (2002) found a strong positive association between liver blood flow and MCR of progesterone in lactating dairy cows. Their highest feed intake group (15.2 kg of dry matter consumed within the first 4 hours) had a $3500 \mathrm{l} / \mathrm{h}$ MCR of progesterone at 4 hours post-feeding. In the current study we found a MCR of progesterone at 4 hours post-feeding in cows consuming $25 \mathrm{~kg}$ of dry matter to be approximately 3300 and 5100 1/h in the high cornstarch versus the high fiber diet, respectively. This depression in MCR of progesterone was not accompanied by a decrease in liver blood flow, which averaged $1891 \pm 91 \mathrm{l} / \mathrm{h}$, strengthening the notion that 
decreasing progesterone catabolic enzyme activity in the liver by modifying the type of energy provided can lower the rate of progesterone inactivation. Miller et al. (1963) estimated a half-life of $33.8 \mathrm{~min}$ for progesterone in dairy cows that were infused with radiolabeled progesterone. These half-life measurements in dairy cows are similar to our own estimates, which are much shorter compared to estimates in beef heifers of 113 to 170 min (Hawkins et al. 1995).

In summary, feeding a high cornstarch diet compared to a high fiber diet stimulated insulin secretion and lowered hepatic cytochrome P450 activity. Liver blood flow was not different after altering energy source, while the MCR of progesterone tended to be lower in cows consuming the high cornstarch diet compared to the high fiber diet. The half-life of progesterone, measured at a similar time compared to the time of liver biopsy, was increased 3 -fold in cows consuming the high cornstarch diet versus the high fiber diet. The type of energy provided can modulate the rate of progesterone inactivation in the liver. Feeding a diet that stimulates insulin secretion during early pregnancy may improve peripheral concentrations of progesterone. Moreover, elevated progesterone has been associated with increased pregnancy retention and advancement in embryonic development, which could improve reproductive performance during early lactation.

\section{Declaration of interest}

The authors declare that there is no conflict of interest that could be perceived as prejudicing the impartiality of the research reported. 


\section{Funding}

This project was supported by National Research Initiative Competitive Grant no. 200835203-04503 from the USDA Cooperative State Research, Education, and Extension Service and Hatch project 468 (NE 1007).

\section{Acknowledgements}

The authors would like to thank the employees of the NDSU Dairy Research and

Teaching Center. This work is published with the approval of the Director of West Virginia Agriculture and Forestry Experiment Station as scientific paper 3066. 


\section{References}

Association of Official Analytical Chemists 1995 Official Methods of Analysis vol I. 15 ${ }^{\text {th }}$ edn, AOAC, Arlington, Va.

Butcher RL 1977. Changes in gonadotropins and steroids associated with unilateral ovariectomy of the rat. Endocrinology $101830-840$.

Butler ST, Pelton SH \& Butler WR 2004 Insulin increases 17 $\beta$-estradiol production by the dominant follicle of the first post-partum follicle wave in dairy cows. Reproduction 127 537-545.

Costine BA, Inskeep EK, Blemings KP, Flores JA \& Wilson ME 2007 Mechanisms of reduced luteal sensitivity to prostaglandin F2alpha during maternal recognition of pregnancy in ewes. Domest Anim Endocrinol 32 106-121.

Csapo A 1956 Progesterone block. Am J Anat 98 273-292.

Cunningham KD, Cecava MJ \& Johnson TR 1993 Nutrient digestion, nitrogen and amino acid flows in lactating cows fed soybean hulls in place of forage or concentrate. $J$ Dairy Sci 76, 3523-3535.

Deriaz RE 1961 Routine analysis of carbohydrates and lignin in herbage. J Sci Food Agri 12 152-160.

Hawkins DE, Niswender KD, Oss GM, Moeller CL, Odde KG, Sawyer HR \& Niswender GD 1995 An increase in serum lipids increases luteal lipid content and alters the disappearance rate of progesterone in cows. J Anim Sci 73 541-545.

Larson SF, Butler WR \& Currie WB 2007 Pregnancy rates in lactating dairy cattle following supplementation of progesterone after artificial insemination. Anim Reprod Sci 102 172-179.

Lemley CO, Koch JM, Blemings KP, Krause KM \& Wilson ME 2008a Concomitant changes in progesterone catabolic enzymes, cytochrome P450 2C and 3A, with plasma insulin concentrations in ewes supplemented with sodium acetate or sodium propionate. Animal 2 1223-1229.

Lemley CO, Butler ST, Butler WR \& Wilson ME 2008b Short communication: insulin alters hepatic progesterone catabolic enzymes, cytochrome P450 2C and 3A, in dairy cows. J Dairy Sci 91 641-645.

Lemley CO, Koch JM, Blemings KP \& Wilson ME 2009 Alterations in progesterone catabolic enzymes, CYP2C and CYP3A, in hepatocytes challenged with insulin and glucagon. J Anim Vet Adv 8 39-46. 
Mann GE \& Lamming GE 1999 The influence of progesterone during early pregnancy in cattle. Reprod Dom Anim 34 269-274.

Mansfield HR \& Stern MD 1994 Effects of soybean hulls and lignosulfonate-treated soybean meal on rumen fermentation in lactating dairy cows. J Dairy Sci 77 1070-1083.

McDonald LE, Nichols RE \& McNutt SH 1952 Studies on corpus luteum ablation and progesterone replacement therapy during pregnancy in the cow. Am J Vet Res 13 446-451.

Miller WR,Williams R, Pipes GW \& Turner CW 1963 Conjugation, distribution, and biological half-life of radioactive progesterone in plasma and red cells of bovine blood. J Dairy Sci 46 1402-1404.

Murray M 1991 Microsomal cytochrome P450-dependent steroid metabolism in male sheep liver. Quantitative importance of $6 \beta$-hydroxylation and evidence for the involvement of a P450 from the IIIA subfamily in the pathway. J Steroid Biochem Molec Biol 38 611-619.

Murray M 1992 Participation of a cytochrome P450 enzyme from the 2C subfamily in progesterone 21-hydroxylation in sheep liver. J Steroid Biochem Molec Biol 43 591-593.

National Research Council 2001 Nutrient Requirements of Dairy Cattle $7^{\text {th }}$ rev edn, Natl. Acad. Press, Washington, DC.

Nelson AC, Huang W \& Moody DE 2001 Variables in human liver microsome preparation: Impact on the kinetics of L-alpha-acetylmethadol (LAAM) Ndemethylation and dextromethorphan O-demethylation. Drug Metabolism and Disposition 29 319-325.

Palackal NT, Lee SH, Harvey RG, Blair IA \& Penning TM 2002 Activation of polycyclic aromatic hydrocarbon trans-dihydrodiol proximate carcinogens by human aldoketo reductase (AKR1C) enzymes and their functional overexpression in human lung carcinoma (A549) cells. J Biol Chem 277 24799-24808.

Parr RA, Davis IF, Miles MA \& Squires TJ 1993a Feed intake affects metabolic clearance rate of progesterone in sheep. Res Vet Sci 55 306-310.

Parr RA, Davis IF, Miles MA \& Squires TJ 1993b Liver blood flow and metabolic clearance rate of progesterone in sheep. Res Vet Sci 55 311-316.

Penning TM, Burczynski ME, Jez JM, Hung C, Lin H, Ma H, Moore M, Palackal N \& Ratnam K 2000 Human 3 $\alpha$-hydroxysteroid dehydrogenase isoforms (AKR1C1- 
AKR1C4) of the aldo-keto reductase superfamily: functional plasticity and tissue distribution reveals roles in the inactivation and formation of male and female sex hormones. Biochemical Journal 351 67-77.

Penning TM, Burczynski ME, Jez JM, Lin H, Ma H, Moore M, Ratnam K \& Palackal N 2001 Structure-function aspects and inhibitor design of type $517 \beta$-hydroxysteroid dehydrogenase (AKR1C3). Molecular and Cellular Endocrinology 171 137-149.

Penning TM, Jin Y, Steckelbroeck S, Rizner L \& Lewis M 2004. Structure-function of human $3 \alpha$-hyrdoxysteroid dehydrogenases: genes and proteins. Molecular and Cellular Endocrinology 215, 63-72.

Rhinehart JD, Starbuck-Clemmer MJ, Flores JA, Milvae RA, Yao J, Poole DH \& Inskeep EK 2009 Low peripheral progesterone and late embryonic/early fetal loss in suckled beef and lactating dairy cows. Theriogenology 71 480-490.

Saad B, Thomas H, Schawalder H, Waechter F \& Maier P 1994 Oxygen tension, insulin, and glucagon affect the preservation and induction of cytochrome P450 isoforms in cultured rat hepatocytes. Toxic Appl Pharmacol 126 372-379.

Sahi J, Reyner EL, Bauman JN, Gueneva-Boucheva K, Burleigh JE \& Thomas VH 2002 The effect of bergamottin on diazepam plasma levels and P450 enzymes in beagle dogs. Drug Metabolism and Disposition 30 135-140.

Sangsritavong S, Combs DK, Sartori R, Armentano LE \& Wiltbank MC 2002 High feed intake increases liver blood flow and metabolism of progesterone and estradiol$17 \beta$ in dairy cattle. J Dairy Sci 85 2831-2842.

Sarwar MJ, Firkins JL \& Eastridge ML 1992 Effects of varying forage and concentrate carbohydrates on nutrient digestibilities and milk production by dairy cows. $J$ Dairy Sci 75 1533-1542.

Savlik M, Polackova L, Szotakova B, Lamka J, Velik J \& Skalova L 2007 Activities of biotransformation enzymes in pheasant (Phasianus colchicus) and their modulation by in vivo administration of mebendazole and flubendazole. Research in Veterinary Science 83 20-26.

Sheffel CE, Pratt BR, Ferrell WL \& Inskeep EK 1982 Induced corpora lutea in the postpartum beef cow. II. Effects of treatment with progestogen and gonadotropins. J Anim Sci 54 830-836.

Shimada H, Miura K \& Imamura Y 2006 Characteristics and inhibition by flavonoids of $20 \alpha$-hydroxysteroid dehydrogenase activity in mouse tissues. Life Sciences $\mathbf{7 8}$ 2931-2936. 
Sievert SJ \& Shaver RD 1993 Carbohydrates and Aspergillus oryzae effects on intake, digestion, and milk production by dairy cows. J Dairy Sci 76 245-254.

Smith D 1969 Removing and analyzing total nonstructural carbohydrates from plant tissue. Wisconsin Agric. Exp. Sta. Res. Rep. 41. p 1. Madison, WI.

Smith DL, Stinefelt BM, Blemings KP \& Wilson ME 2006 Diet-induced alterations in progesterone clearance appear to be mediated by insulin signaling in hepatocytes. J Anim Sci 84 1102-1109.

Stevenson JS, Portaluppi MA, Tenhouse DE, Lloyd A, Eborn DR, Kacuba, S \& DeJarnette JM 2007 Interventions after artificial insemination: Conception rates, pregnancy survival, and ovarian responses to gonadotropin-releasing hormone, human chrionic gonadotropin, and progesterone. J Dairy Sci 90 331-340.

Swanson KS, Merchen NR, Erdman Jr JW, Drackley JK, Orias F, Douglas GN \& Huhn JC 2000 Technical note: a technique for multiple liver biopsies in neonatal calves. J Anim Sci 78 2459-2463.

Szotakova B, Baliharova V, Lamka J, Nazinova E, Wsol V, Velik J, Machala M, Neca J, Soucek P, Susova S \& Skalova L 2004 Comparison of in vitro activities of biotransformation enzymes in pig cattle goat and sheep. Research in Veterinary Science 76 43-51.

Thomford PJ \& Dziuk PJ 1986 The influence of dose of phenobarpital and interval to measurement on concentration of liver enzymes in barrows and gilts. $J$ Anim Sci 63 1184-1190.

Van Knegsel ATM, van den Brand H, Dijkstra J, Tamminga S \& Kemp B 2007 Effect of glucogenic vs. lipogenic diets on energy balance, blood metabolites, and reproduction in primiparous and multiparous dairy cows in early lactation. $J$ Dairy Sci 90 3397-3409.

Zangar RC \& Novak RF 1998 Posttranslational elevation of cytochrome P450 3A levels and activity by dimethyl sulfoxide. Arch Biochem Biophy 353 1-9. 


\section{EFFECT OF CYTOCHROME P450 AND ALDO-KETO REDUCTASE INHIBITORS ON PROGESTERONE DECAY IN PRIMARY BOVINE HEPATIC CELL CULTURES ${ }^{1}$ \\ C. O. Lemley and M. E. Wilson ${ }^{2}$ \\ Division of Animal and Nutritional Sciences, Davis College of Agriculture, Natural Resources and Design, West Virginia University, Morgantown, WV, 26506}

\footnotetext{
${ }^{1}$ This work is published with the approval of the Director of West Virginia Agriculture and Forestry Experiment Station as scientific paper ////. This project was supported by National Research Initiative Competitive Grant no. 2008-35203-04503 from the USDA Cooperative State Research, Education, and Extension Service and Hatch project 468 (NE 1007).

${ }^{2}$ Corresponding author: mwilso25@wvu.edu
} 


\begin{abstract}
Progesterone is required for maintenance of pregnancy and peripheral concentrations of progesterone are affected by both production and inactivation. Hepatic cytochrome $\mathrm{P} 450$ (CYP; EC 1.14.14.1) and aldo-keto reductase (AKR; EC 1.1.1.145-151) enzymes play a pivotal role in the first step of steroid inactivation, which involves the addition of hydroxyl groups to various sites of the cyclopentanoperhydrophenanthrene nucleus. The current objective was to discern the proportional involvement of hepatic progesterone catabolic enzymes on progesterone decay using specific enzyme inhibitors. Ticlopidine, diltiazem, curcumin, dicumarol and naproxen were used due to their selective inhibition of cytochrome P450s, aldo-keto reductases and glucuronosyltransferases. Liver biopsies were collected from six lactating Holstein dairy cows and cells were dissociated using a non-perfusion technique. Confluent wells $(\mathrm{n}=12 /$ treatment $)$ were preincubated for four hours with enzyme inhibitor and then challenged with progesterone for one hour. Cell viability was unaffected by inhibitor treatment and averaged $84 \pm 1 \%$. In control wells, $50 \%$ of the progesterone had been inactivated after a one hour challenge with $5 \mathrm{ng} / \mathrm{ml}$ progesterone. Preincubation with curcumin, ticlopidine or naproxen caused the greatest reduction in progesterone decay compared to controls and averaged $77 \%, 39 \%$ or $37 \%$, respectively. Hydroxylation of 4-nitrophenol to 4-nitrocatechol in intact cells was inhibited by $\sim 65 \%$ after treatment with curcumin or ticlopidine. Glucuronidation of phenol red or 4-nitrocatechol in intact cells was inhibited by treatment with curcumin, dicumarol or naproxen. In cytoplasmic preparations, AKR1C activity was inhibited by curcumin, dicumarol or naproxen treatment. Microsomal CYP2C activity was inhibited by treatment with curcumin or ticlopidine, while CYP3A activity was inhibited by
\end{abstract}


treatment with curcumin or diltiazem. The contribution of CYP2C and CYP3A enzymes to progesterone inactivation in bovine hepatic cell cultures was $40 \%$ and $15 \%$, respectively. Depending on the inhibitor used, it would appear that the aldo-keto reductase enzymes contribute $\sim 40 \%$ to the observed progesterone decay; although, a portion of this inactivation may be due to the loss of glucuronosyltransferase activity. Future work focusing on decreasing the activity of these enzymes in vivo could lead to an increase in the bioavailability of progesterone.

Key Words: cytochrome P450, aldo-keto reductase, progesterone decay, hepatic cell isolation, dairy cow 


\section{Introduction}

Several reviews have addressed the issue of low fertility in the lactating dairy cow, and an increasing number of observations have associated metabolic demand, as a result of continued selection for milk yield, with altered hormonal profiles and fertility (Chagas et al., 2007; Leroy et al., 2008). Several studies have focused on progesterone production during the estrous cycle and various cellular mechanisms and models have been elucidated in controlling luteal function (Niswender et al., 2000; Schams and Berisha, 2004). However, elevated rates of steroid inactivation may contribute to lower concentrations of progesterone in the pregnant lactating dairy cow (Rhinehart et al., 2009). Independent reports have shown a positive relationship between the metabolic clearance rate of progesterone and liver blood flow in both the sheep and dairy cow (Parr et al., 1993; Sangsritavong et al., 2002). Recently, our laboratory observed a longer halflife of progesterone in dairy cows fed an insulin stimulating diet that decreased the activity of cytochrome P450 2C and 3A (CYP2C; CYP3A; Lemley et al., 2010). In addition, supplementing diets with lipids lengthened the half-life of progesterone in beef

cows (Hawkins et al., 1995). In the pig, the metabolic clearance rate of progesterone was not correlated with total cytochrome P450 content in the liver after altering feed intake; however, total cytochrome P450 content was positively correlated with the rate of progesterone inactivation in vitro (Miller et al., 1999). Furthermore, induction of mixed function monooxygenases (cytochrome P450 superfamily) using phenobarbital can alter the rate of steroid clearance in the barrow and gilt (Thomford and Dziuk, 1986).

The cytochrome P450 superfamily (located in the endoplasmic reticulum or microsomal cellular fractions) of enzymes are involved in a number of pathways 
including endogenous vitamin D3 activation, metabolism of cholesterol to bile acids, metabolism of all major classes of steroid hormones (Waxman et al., 1991), and xenobiotic metabolism (Anzenbacher and Anzenbacherova, 2001). Waxman et al. (1991) determined that progesterone was primarily metabolized to $6 \beta$-hydroxyprogesterone and 16a-hydroxyprogesterone along with two other unknown metabolites by CYP3A4, CYP3A3, CYP4B1, CYP3A5 and CYP2C8, in order of highest activity to lowest. In sheep liver, CYP2C and CYP3A metabolized progesterone to 21-hydroxyprogesterone (deoxycorticosterone) and 6ß-hydroxyprogesterone, respectively (Murray, 1991; 1992). The total microsomal contributions to progesterone inactivation were determined to be 25\% for CYP2C and 55\% for CYP3A in sheep (Murray, 1991; 1992).

The aldo-keto reductase superfamily of enzymes are involved in the reduction of glucose, prostaglandin metabolism, generation of bile acids and reduction of steroids containing aldehyde or ketone groups (Penning et al., 2000; Barski et al., 2008; Kabututu et al., 2009). Aldo-keto reductase 1C subfamily (AKR1C), are involved in converting progesterone to $3 \alpha$-hydroxyprogesterone or $20 \alpha$-hydroxyprogesterone in humans and rodents (Penning et al., 2000). In the human, all 4 isoforms of AKR1C (AKR1C1, AKR1C2, AKR1C3 and AKR1C4) were highly expressed in the liver (Penning et al., 2000). The second phase of steroid biotransformation, generation of a more hydrophilic pregnandiol metabolite, involves UDP-glucuronosyltransferase (UGT) enzymes, which conjugate the inactive hydroxysteroid metabolites with glucuronic acid. UGT1A and UGT2B have been implicated in glucuronidation of hydroxylated derivatives of C18, C19 and C21 steroids (Bowalgaha et al., 2007). 
These previous studies in sheep, rodents and humans cannot be extrapolated to the lactating dairy cow. Moreover it does not seem reasonable to estimate the relative contributions of metabolizing enzymes to the rate of progesterone inactivation in cytosolic versus microsomal protein fractions from independent reports. Despite numerous reports implicating low progesterone in the observed low fertility in dairy cows, the contributions of CYP, AKR and UGT enzymes in the dairy cow have not garnered much attention. In addition, we felt it was necessary to study hepatic cultures from early lactating dairy cows because of the metabolic differences observed in lactating versus non-lactating sheep hepatocyte cultures (Emmison et al., 1991). The objectives of the current experiment were to determine the contributions of steroid biotransformation enzymes (CYP, AKR and UGT) to total progesterone decay in primary hepatic cell cultures from early lactation dairy cows using specific enzyme inhibitors.

\section{Materials and Methods}

\section{Tissue collection}

In a preliminary experiment, liver tissue was collected from animals undergoing euthanasia for an independent project (2 pigs and 2 dairy cows) and used to optimize cell dissociation techniques, progesterone decay and cell viability after enzyme inhibitor challenges, which are described below. Following the preliminary experiments, liver biopsies were collected from six lactating Holstein dairy cows on three separate days $(\mathrm{n}=$ 3 replicates), housed at the West Virginia University Animal Sciences Farm (Morgantown, WV), averaging $54 \pm 4$ days in milk and $47.0 \pm 2.6 \mathrm{~kg}$ of milk production per day. Liver biopsies were taken approximately 4 hours after the scheduled 0800 hour

milking and feeding. Briefly, hair was removed from the animals' right side and the skin 
was scrubbed twice with betadine (Columbus Serum, Columbus, $\mathrm{OH}$ ). After determining the location of the tenth intercostal space, $2 \%$ lidocaine hydrochloride (Columbus Serum, Columbus, $\mathrm{OH}$ ) was administered as a local anesthetic. The skin was punctured using a scalpel and the liver samples were collected using a biopsy needle machined at the West Virginia University Physics Department (Morgantown, WV) following the specifications of Swanson et al. (2000). Liver samples were blotted on sterile gauze to remove any excess blood, immersed in HEPES buffered salt solution (HBSS; 10 mM HEPES, 136 $\mathrm{mM}$ sodium chloride, $5 \mathrm{mM}$ potassium chloride and $27 \mathrm{mM}$ glucose; $\mathrm{pH}=7.4$ ) containing $0.05 \mathrm{mM}$ EGTA and transported to the laboratory on ice within 1 hour of collection. Animal care and use were according to a protocol approved by the West Virginia University Animal Care and Use Committee (ACUC \#07-0503).

\section{Cell dissociation}

Cells were dissociated using a non-perfusion technique (modified from Spotorno et al., 2006). Liver tissue was finely minced with a scalpel blade and washed three times in HBSS containing $0.05 \mathrm{mM}$ EGTA by centrifugation at $50 \mathrm{x}$ g for three minutes. Tissue was then washed three times with HBSS by centrifugation at $50 \mathrm{x} \mathrm{g}$ for three minutes and suspended in $150 \mathrm{ml}$ of HBSS containing $1 \mathrm{mM}$ calcium chloride and 150 U/ml type 1A collagenase (Sigma Chemical Co., St Louis, MO). Tissue was incubated with collagenase for 45 minutes at $37^{\circ} \mathrm{C}$ with gentle shaking. After the 1 hour incubation $50 \mathrm{ml}$ of Dulbecco's modified Eagle's medium: Ham's nutrient mixture F-12 (DMEM/F-12; 1:1 ratio; ATCC, Manassas, VA) containing 10\% fetal bovine serum (FBS; Thermo Fisher Scientifics, Waltham, MA) was added to the solution. The cell and tissue suspension was then processed through 425, 212 and $106 \mu \mathrm{m}$ stainless steel sieves. Cell 
suspensions were centrifuged at $100 \mathrm{x}$ g for 5 minutes and pellets were washed twice with Hank's buffered salt solution (Hanks; $5.3 \mathrm{mM}$ potassium chloride, $0.4 \mathrm{mM}$ monobasic potassium phosphate, $4.2 \mathrm{mM}$ sodium bicarbonate, $137.9 \mathrm{mM}$ sodium chloride, $0.3 \mathrm{mM}$ dibasic sodium phosphate and $5.6 \mathrm{mM}$ glucose; $\mathrm{pH}=7.4$ ). Cell viability and yield (Table 8) was determined using trypan blue stain (Invitrogen, Carlsbad, CA) and a Bright-line hemacytometer (Hausser Scientific, Horsham, PA).

\section{Cell culture}

Hepatic cells were plated on 24 well tissue culture treated polystyrene plates (Becton Dickinson Labware, Franklin Lakes, NJ) at a density of 0.8 to $1.2 \times 10^{6}$ viable cells/well, in growth media. Growth media contained D-MEM/F-12 media with the addition of 10\% FBS, $500 \mathrm{IU} / \mathrm{ml}$ penicillin (Invitrogen, Carlsbad, CA), $500 \mu \mathrm{g} / \mathrm{ml}$ streptomyocin (Invitrogen, Carlsbad, CA), 10 nM insulin (Sigma Chemical Co., St Louis, MO), 1 nM glucagon (Sigma Chemical Co., St Louis, MO), 10 ng/ml epidermal growth factor (Invitrogen, Carlsbad, CA) and $10 \mathrm{nM}$ dexamethasone (Thermo Fisher Scientifics, Waltham, MA) sterile filtered with $0.22 \mu \mathrm{m}$ polyethersulfone filters (Fisher Scientific, Wilkes Barre, PA). Growth media was replaced every 24 hours and cultures were maintained in an incubator set at $37^{\circ} \mathrm{C}$ under a humidified gas mixture of $95 \%$ air and $5 \%$ carbon dioxide.

\section{Fluorescence staining and image analysis}

Cells were cultured on glass cover slips coated in poly L-lysine (Sigma) and allowed to reach 80 to $90 \%$ confluence before preparing cover slips for 
Table 8. Liver biopsies from six lactating dairy cows used for cell culture experiments. Stage of lactation, milk yield and liver biopsy weight for individual dairy cows, and cell yield and viability following tissue dissociation using a non-perfusion technique.

\begin{tabular}{cccccc}
\hline Cow ID & $\begin{array}{c}\text { Days in } \\
\text { Milk }\end{array}$ & $\begin{array}{c}\text { Milk yield } \\
(\mathrm{kg})\end{array}$ & $\begin{array}{c}\text { Liver } \\
\text { sample }(\mathrm{g})\end{array}$ & $\begin{array}{c}\text { Cell yield } \\
\left(10^{6}\right)\end{array}$ & $\begin{array}{c}\text { Cell } \\
\text { Viability (\%) }\end{array}$ \\
\hline 273 & 67 & 46.4 & 0.92 & 36 & 85 \\
285 & 57 & 54.5 & 0.94 & 75 & 91 \\
300 & 41 & 50.5 & 1.31 & 37 & 91 \\
305 & 46 & 51.8 & 1.21 & 25 & 71 \\
314 & 54 & 39.5 & 0.79 & 28 & 70 \\
325 & 56 & 39.1 & 1.01 & 48 & 89 \\
\hline Mean & 54 & 47.0 & 1.03 & 42 & 83 \\
SEM & 4 & 2.6 & 0.08 & 7 & 4 \\
\hline
\end{tabular}


immunocytochemistry. Growth and morphology remained similar between cells grown on glass cover slips and tissue culture treated polystyrene plates. Growth media was replaced with serum free and phenol red free D-MEM/F-12 media (Invitrogen, Carlsbad, CA) containing $500 \mathrm{IU} / \mathrm{ml}$ penicillin and $500 \mu \mathrm{g} / \mathrm{ml}$ streptomyocin (serum free media) 24 hours prior to staining. Cell cultures were washed with phosphate buffered saline (PBS, $\mathrm{pH}=7.3)$ and fixed with buffered neutral formalin (10\%; VWR International, Bridgeport, NJ) for 15 min at RT. Cell cultures were washed twice with PBS and incubated for 10 min with PBS containing Tween $20(0.3 \%)$. Cells were washed three times with PBS for 5 min and incubated with blocking buffer (PBS $+0.3 \%$ Tween $20+1 \%$ gelatin) for 30 min at RT. Primary and secondary antibodies were incubated for one hour at RT. Antibodies were purchased from Abcam Inc, Cambridge, MA (mouse monoclonal antiactin; goat polyclonal anti-mouse $\operatorname{IgG}$ conjugated with phycoerythrin, PE; sheep polyclonal anti-bovine serum albumin; rabbit polyclonal anti-sheep IgG conjugated with fluorescein-5-isothiocyanate, FITC). Following each antibody incubation cells were washed three times with PBS. At the end of the antibody incubations, a subset of the cell cultures were incubated for $1 \mathrm{~min}$ with $0.05 \mathrm{mM}$ Hoechst 33258 (Sigma Chemical Co.) diluted in automation buffer (138 mM sodium chloride, $20.1 \mathrm{mM}$ Tris hydrochloride, $4.87 \mathrm{mM}$ Tris base). Stained cover slips were mounted with Fluoromount (Sigma Chemical Co.) and cells were visualized using a Nikon Eclipse TE2000-S inverted microscope equipped with a 100W-mercury vapor lamp. UV, blue and green filter sets were used to detect Hoechst, FITC and PE fluorescence, respectively. Pictures were taken with a Q Imaging Retiga 2000R camera using Q capture 2.90.1 software (Quantitative Imaging Corporation, Surrey, BC, Canada). Pictures of the fluorescent 
images were merged using Northern Eclipse software (Empix Imaging, Inc., Cheektowaga, NY).

\section{Enzyme inhibitors}

All inhibitors were purchased from Sigma Chemical Co. (St Louis, MO), and had been previously shown to inhibit CYP, AKR and UGT enzymes (Table 9). Stock solutions of 0.1 M ticlopidine (CYP2C inhibitor; Ko et al., 2000) in methanol, 0.1 M diltiazem (CYP3A inhibitor; Jones et al., 1999) in water, $27 \mathrm{mM}$ curcumin (CYP and UGT inhibitor; Basu et al., 2005; Volak et al., 2008) in dimethyl sulfoxide, $4 \mathrm{mM}$ dicumarol (UGT inhibitor; Segura-Aguilar et al., 1986) in methanol and 0.1 M naproxen (AKR inhibitor; Yee et al., 2006) in acetone were prepared. All inhibitors were diluted in $5 \mathrm{ml}$ of serum free media to reach final concentrations of $50 \mu \mathrm{M}$ ticlopidine, $50 \mu \mathrm{M}$ diltiazem, $20 \mu \mathrm{M}$ curcumin, $20 \mu \mathrm{M}$ dicumarol and $50 \mu \mathrm{M}$ naproxen. Treatments using methanol or acetone as a vehicle were between 0.05 to $0.50 \%$ in the final solution.

\section{Progesterone decay}

Experiments were started once cell cultures reached 80 to $90 \%$ confluence and cells were determined to be metabolically active due to the disappearance of phenol red from the growth media (averaging $14 \pm 2$ days in culture at the time of experimentation). Progesterone decay was determined in duplicates ( 2 wells/cow) for each of the six dairy cows biopsied $(\mathrm{n}=12)$. The day prior to experimentation, growth media was replaced with serum free media (absent of phenol red to remove any confounding effects of phenol red metabolism on progesterone decay) and an identical plate containing no cells was cultured under the same experimental conditions. Twenty-four hours later, the media was 
Table 9. Enzyme inhibitors, phase I or phase II of steroid biotransformation, used for intact cell culture and fractionated tissue experiments.

\begin{tabular}{lccll}
\hline $\begin{array}{l}\text { Enzyme } \\
\text { Inhibitors }\end{array}$ & Phase I & Phase II & $\begin{array}{l}\text { Type of } \\
\text { Inhibition }\end{array}$ & Reference \\
\hline Ticlopidine & CYP2C & - & Competitive & Ko et al. (2000) \\
Diltiazem & CYP3A & - & Irreversible & Jones et al. (1999) \\
Curcumin & CYP & UGT & Mixed & Basu et al. (2005); Volak et al. (2008) \\
Dicumarol & - & UGT & Competitive & Segura-Aguilar et al. (1986) \\
Naproxen & AKR & - & - & Yee et al. (2006) \\
\hline
\end{tabular}


replaced with serum free media containing no inhibitor or enzyme inhibitor for four hours. Following the four hour enzyme inhibition, media was replaced with serum free media containing $5 \mathrm{ng} / \mathrm{ml}$ progesterone with no inhibitor or enzyme inhibitor and incubated for one hour. A stock solution of $5 \mu \mathrm{g} / \mathrm{ml}$ progesterone was prepared in ethanol and diluted to $5 \mathrm{ng} / \mathrm{ml}$ in $5 \mathrm{ml}$ of serum free media $(0.1 \%$ ethanol in final solution). Media from plates containing cells or no cells were analyzed for progesterone concentrations using radioimmunoassay (Sheffel et al., 1982) with a sensitivity of 100 $\mathrm{pg} / \mathrm{ml}$.

\section{4-nitrophenol and phenol red metabolism}

Experiments were started once cell cultures reached 80 to $90 \%$ confluence. 4 nitrophenol and phenol red metabolism was determined in duplicates ( 2 wells/cow) for each of the six dairy cows biopsied $(\mathrm{n}=12)$. The day prior to experimentation growth media was replaced with serum free media (absent of phenol red to remove any confounding effects of phenol red metabolism on 4-nitrophenol metabolism) and an identical plate containing no cells was cultured under the same experimental conditions. Twenty-four hours later the media was replaced with serum free media containing no inhibitor or enzyme inhibitor for four hours. The cells were then challenged with serum free media containing $200 \mu \mathrm{M}$ 4-nitrophenol (Sigma Chemical Co.) and the respective inhibitor or no inhibitor controls for four hours. Hydroxylation of 4-nitrophenol has been used as a specific substrate for CYP2E1 activity; however, CYP2A, CYP2C and CYP3A have been shown to contribute to the hydroxylation of 4-nitrophenol to 4-nitrocatechol (Table 10; Monostory et al., 2004; Zerilli et al., 1997). Formation of glucuronide conjugated 4-nitrocatechol was used to assess UDP-glucuronosyltransferase inhibition 
Table 10. Substrates used for enzymatic activity assays in intact cell cultures or fractionated tissue preparations.

\begin{tabular}{lccl}
\hline Enzyme Substrates & Phase I & Phase II & Reference \\
\hline 4-nitrophenol & CYP2 & UGT & Monostory et al. (2004); Zerilli et al. (1997) \\
Phenol red & - & UGT & Behnia et al. (2000) \\
1-acenapthenol & AKR1C & - & Savlik et al. (2007) \\
Omeprazole & CYP2C & - & Lemley et al. (2008) \\
Nifedipine & CYP3A & - & Lemley et al. (2008) \\
\hline
\end{tabular}


(Table 10). After the incubation media was collected the cells were harvested using trypsin (Invitrogen, Carlsbad, CA) and stained with trypan blue stain to determine cell number and viability. The conversion of 4-nitrophenol to 4-nitrocatechol was determined using a Spectra max Plus plate reader (Molecular Devices, Inc., Sunnyvale, CA) adapted from David et al. (1998). Incubated media (100 $\mu \mathrm{l}$; in duplicate) was split into two tubes and either combined with $1.9 \mu \mathrm{l}$ of $5 \%$ acetic acid and $5 \mu \mathrm{l}$ of acetate buffer (measurement of unconjugated 4-nitrocatchol) or $5 \mu$ acetate buffer containing 50 Units $\beta$-glucuronidase (to measure conjugated 4-nitrocatechol, Sigma Chemical Co.) and incubated for 90 min at RT (adapted from Reinke and Moyer, 1985). Following the 90 min incubation the solution was combined with $20 \mu$ of sodium hydroxide $(5 \mathrm{M})$ and the absorbance was determined at $546 \mathrm{~nm}$ against a standard curve of 4-nitrocatechol (0 to $250 \mu \mathrm{M}$ ). Total 4-nitrocatechol formation (hydroxylation of 4-nitrophenol) is reported as the sum of conjugated and unconjugated metabolites (Reinke and Moyer, 1985). The glucuronide conjugate is reported as the amount of 4-nitrocatechol measured following the 90 min exposure to $\beta$-glucuronidase. Conjugated and unconjugated 4-nitrocatechol is reported as nmol/hr* $10^{6}$ cells.

Measurement of phenol red glucuronidation was adapted from Behnia et al. (2000) and used to assess UDP-glucuronosyltransferase inhibition (Table 10). The day prior to experimentation growth media was replaced with serum free media containing phenol red and an identical plate containing no cells was cultured under the same experimental conditions. Twenty-four hours later the media was replaced with serum free media containing phenol red with the addition of no inhibitor or enzyme inhibitor for six hours. Following the six hour incubation, media was collected and the cells were 
harvested using trypsin (Invitrogen, Carlsbad, CA) and stained with trypan blue stain to determine cell number and viability. Incubated media (200 $\mu$, in duplicate) was combined with $3.8 \mu \mathrm{l}$ of $5 \%$ acetic acid and $10 \mu \mathrm{l}$ of acetate buffer or $10 \mu \mathrm{l}$ of acetate buffer containing 100 Units of $\beta$-glucuronidase and incubated for 3 hours at $37^{\circ} \mathrm{C}$. After the 3 hour incubation the solution was combined with $16.5 \mu \mathrm{l}$ of $1 \mathrm{M}$ glycine buffer and the absorbance was determined at $546 \mathrm{~nm}$. The extinction coefficient for phenol red $\left(8450 \mathrm{l} / \mathrm{mol}^{*} \mathrm{~cm}\right)$ was used to express the rate of phenol red glucuronidation in $\mathrm{pmol} / \mathrm{hr} * 10^{6}$ cells

\section{Cellular fractionation and enzymatic activity}

To determine inhibitor specificity for the following enzymes (Table 10) in bovine liver, frozen tissue was fractionated for the following experiments. Dairy cow frozen liver samples $(n=4)$ were submerged in phosphate buffer and homogenized using a Dounce homogenizer. Homogenized tissue was centrifuged at 10,000 $\mathrm{x} g$ for $10 \mathrm{~min}$ and supernatant was collected for experiments using cytoplasmic fractions. Microsomes were collected and concentrated using differential centrifugation techniques (Nelson et al., 2001). Homogenized tissue was centrifuged at $10,000 \mathrm{x}$ g for $10 \mathrm{~min}$. Pellets were discarded and the supernatants were centrifuged at $100,000 \mathrm{x} g$ for $60 \mathrm{~min}$. The microsomal pellets were resuspended in phosphate buffer containing $20 \%$ glycerol. Cytoplasmic and microsomal protein was determined using a Coomassie Plus (Bradford) protein assay following the manufacturer's protocol (Thermo Scientific, Rockford, IL) and used to standardize AKR1C, CYP2C and CYP3A activity. AKR1C activity was determined in cytoplasmic cellular fractions using the specific substrate, 1 -acenapthenol (Sigma Chemical Co.), following the methods of Savlik et al. (2007) and Palackal et al. 
(2002). Briefly, AKR1C enzymatic reactions contained 150 to $650 \mu \mathrm{g}$ of cytoplasmic protein, $250 \mu \mathrm{M} 1$-acenapthenol and $500 \mu \mathrm{M}$ NADP. The 1-acenapthenol-dependent reduction of NADP was standardized using the amount of cytoplasmic protein. CYP2C, CYP3A and cytochrome P450 reductase activity were assessed on frozen liver samples following our previously published protocol (Lemley et al., 2008). CYP2C activity was measured as the non-ketoconazole-inhibitable, omeprazole-dependent oxidation of NADPH. Microsomes were pre-incubated for 15 min with $250 \mu \mathrm{M}$ ketoconazole. CYP2C enzymatic reactions contained CYP3A inhibited microsomes, $2.5 \mathrm{mM}$ omeprazole and $250 \mu \mathrm{M}$ NADPH. CYP3A activity was measured as the nifedipinedependent oxidation of NADPH. CYP3A enzymatic reactions contained microsomes, $200 \mu \mathrm{M}$ nifedipine and $250 \mu \mathrm{M}$ NADPH. AKR1C, CYP2C and CYP3A activity was determined after a 30 minute preincubation with enzyme inhibitors. All inhibitors were purchased from Sigma Chemical Co., St Louis, MO. Stock solutions of 0.1 M ticlopidine in methanol, $0.1 \mathrm{M}$ diltiazem in water, $27 \mathrm{mM}$ curcumin in dimethyl sulfoxide, $4 \mathrm{mM}$ dicumarol in methanol and $0.1 \mathrm{M}$ naproxen in acetone were prepared. All inhibitors were diluted in phosphate buffer, substrates and cellular fractions to reach a final concentration of $50 \mu \mathrm{M}$ or $150 \mu \mathrm{M}$ ticlopidine, $50 \mu \mathrm{M}$ or $150 \mu \mathrm{M}$ diltiazem, $20 \mu \mathrm{M}$ or $60 \mu \mathrm{M}$ curcumin, $20 \mu \mathrm{M}$ or $60 \mu \mathrm{M}$ dicumarol and $50 \mu \mathrm{M}$ or $150 \mu \mathrm{M}$ naproxen, which represents $1 \mathrm{x}$ or $3 \mathrm{x}$ inhibitor concentrations compared to the cell culture experiments. All solutions were added to UV star 96-well plates (PGC Scientifics, Frederick, MD) and the oxidation of NADPH or reduction of NADP was determined by measuring the amount of light absorbed at $340 \mathrm{~nm}$ for $5 \mathrm{~min}$. The extinction coefficient for NADPH $\left(62201 / \mathrm{mol}^{*} \mathrm{~cm}\right)$ 
was used to calculate the rate of oxidized NADPH or reduced NADP in pmol/min*mg of protein.

\section{Statistical analysis}

For the cell culture experiments, the effects of inhibitor on cell viability, progesterone decay, 4-nitrophenol metabolism and phenol red metabolism were tested with the MIXED procedure of SAS (SAS software version 9.1, SAS Institute Inc., Cary, NC). The random statement included cow $(n=6)$ and well $(n=2)$ within cow to denote that duplicate wells were nested within each cow. Means were separated using the PDIFF option of the LSMEANS statement. For the cytosolic and microsomal assays the effects of inhibitor on enzyme activity were tested using the MIXED procedure of SAS and means were separated using the PDIFF option of the LSMEANS statement. Least square means and SEM are reported. Statistical significance was declared at $P<0.05$.

\section{Results}

\section{Cell dissociation and morphology}

Cell yields averaged $40.8 \times 10^{6}$ live cells/g of liver tissue with a cell viability of $83 \%$ (Table 8 ). Based on cellular morphology, $\sim 60 \%$ of the cultured cells had a fibroblastic like appearance, which stained positive for actin (yellow arrows, Figure 8A, B and C). Approximately $25 \%$ of the cultured cells retained the ability to synthesize albumin, which is specific for viable hepatocytes (white arrows, Figure 8A, B and C), while the remainder, $\sim 15 \%$, did not stain positive for actin or albumin (red arrows, Figure $8 \mathrm{~A}$ and $\mathrm{B})$. The negative control did not show appreciable amounts of red or green fluorescence (Figure 8D). 

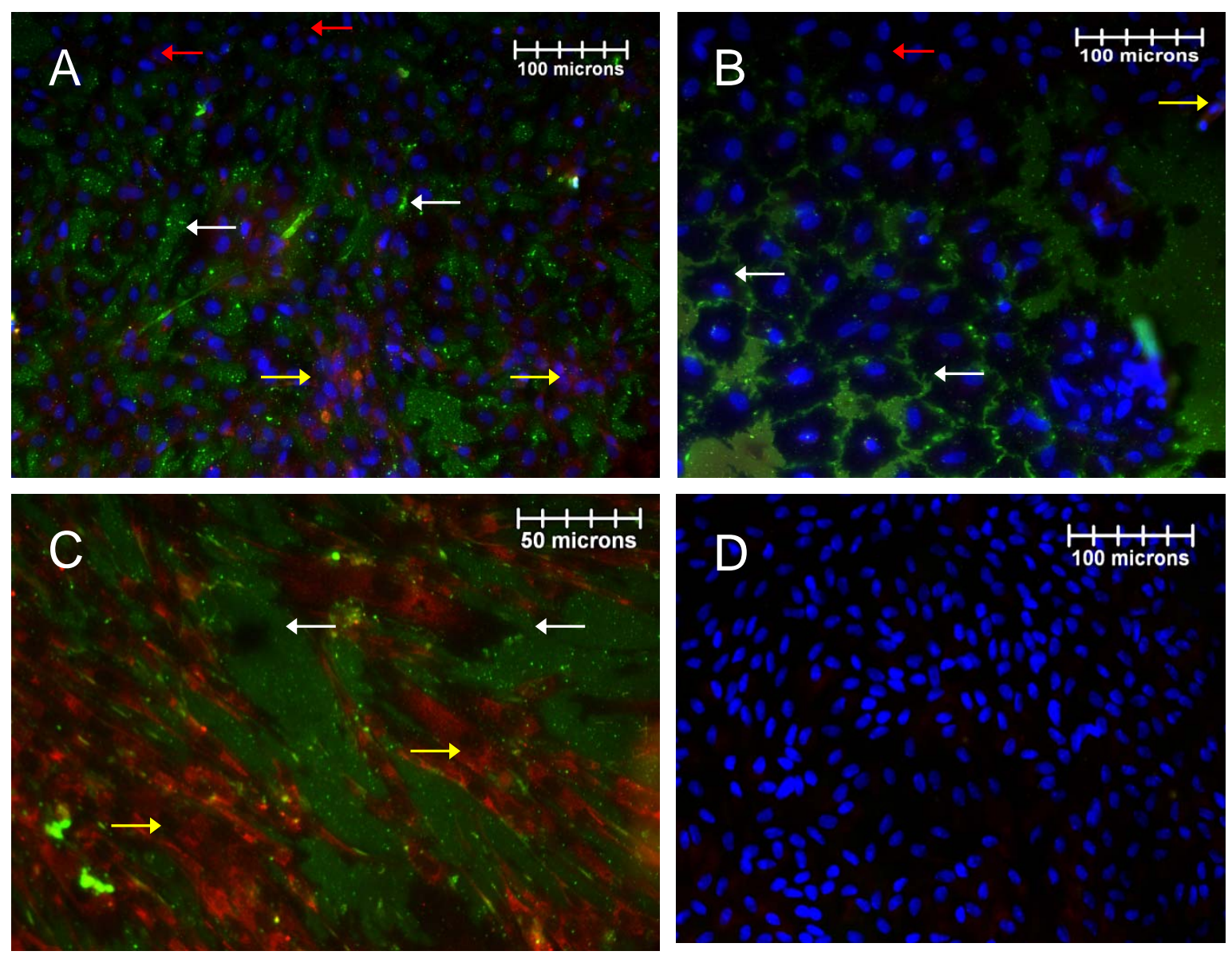

Figure 8. Immunofluorescence images from dairy cow hepatic cell cultures. Cells were stained for albumin (green, FITC), actin (red, PE) and nuclei (blue, Hoechst). Images (A) and $(B)$ were stained for albumin, actin and nuclei. Image $(C)$ was stained for albumin and actin. Image ( $\mathrm{D}$, negative control) was incubated with the secondary antibodies conjugated to fluorophore and nuclei were stained with Hoechst. White, yellow and red arrows highlight cell populations that were positive for albumin, actin or neither, respectively. 


\section{Progesterone decay and cell viability}

In a preliminary experiment, pig and dairy cow hepatic cell cultures were challenged with varying concentrations of inhibitors for different amounts of time in the presence of $5 \mathrm{ng} / \mathrm{ml}$ progesterone to determine cell viability and to estimate the optimal time to study progesterone decay following progesterone exposure. Some inhibitors and all inhibitor combinations were excluded from the study due the decrease in cell viability following exposure. Cell viability in porcine hepatic cultures exposed to no inhibitor, 50 $\mu \mathrm{M}$ ticlopidine, $50 \mu \mathrm{M}$ diltiazem, $20 \mu \mathrm{M}$ curcumin, $20 \mu \mathrm{M}$ dicumarol or $50 \mu \mathrm{M}$ naproxen was not significantly different and averaged $79 \pm 1 \%$. Similarly, cell viability in bovine hepatic cultures exposed to the same inhibitor concentrations was not significantly different and averaged $83 \pm 1 \%$. Progesterone decay in controls (no inhibitor) were $50 \%$ after one hour of culture with $5 \mathrm{ng} / \mathrm{ml}$ progesterone (Table 11). In both porcine and bovine hepatic cultures, treatment with $20 \mu \mathrm{M}$ curcumin resulted in the greatest reduction in progesterone decay, $74 \%$ and $75 \%$, respectively. In porcine hepatic cultures ticlopidine and dicumarol inhibited progesterone decay by $48 \%$ and $31 \%$, respectively (Table 11).

Liver biopsies were taken from six lactating dairy cows (Table 8). Similar to the preliminary experiments, enzyme inhibitors did not alter $(P>0.50)$ cell viability, which averaged $84 \pm 1 \%$. After a one hour culture with $5 \mathrm{ng} / \mathrm{ml}$ progesterone $\sim 50 \%$ of the progesterone had been inactivated (Figure 9A). All of the enzyme inhibitor treatments caused a reduction $(P<0.05)$ in progesterone decay compared to controls (Figure 9A). 
Table 11. Percentage progesterone decay inhibited in a preliminary experiment. Progesterone decay was determined in duplicate in hepatic cultures from 2 pigs $(n=4)$ and 2 dairy cows $(n=4)$.

\begin{tabular}{lcccccccccc} 
& \multicolumn{4}{c}{ Pig } & & \multicolumn{5}{c}{ Cow } \\
\cline { 2 - 6 } \cline { 8 - 9 } Inhibitor & $\begin{array}{c}\% \\
\text { Decay }\end{array}$ & $\begin{array}{c}\% \\
\text { Inhibited }\end{array}$ & SEM & $P$ value & & $\begin{array}{c}\% \\
\text { Decay }\end{array}$ & $\begin{array}{c}\% \\
\text { Inhibited }\end{array}$ & SEM & $P$ value \\
\hline None & 54.8 & & 7.4 & & & 49.6 & & 8.0 & \\
Ticlopidine & 28.7 & 47.6 & 4.5 & $<0.001$ & & 31.0 & 37.5 & 5.5 & 0.081 \\
Diltiazem & 47.3 & 13.6 & 3.9 & 0.489 & & 43.6 & 12.1 & 2.9 & 0.931 \\
Naproxen & 45.6 & 16.8 & 5.2 & 0.249 & & 35.1 & 29.3 & 2.4 & 0.248 \\
Dicumarol & 37.7 & 31.1 & 1.7 & 0.003 & & 36.9 & 25.5 & 3.2 & 0.384 \\
Curcumin & 13.7 & 75.0 & 4.1 & $<0.001$ & & 12.9 & 73.9 & 0.5 & $<0.001$ \\
\hline
\end{tabular}



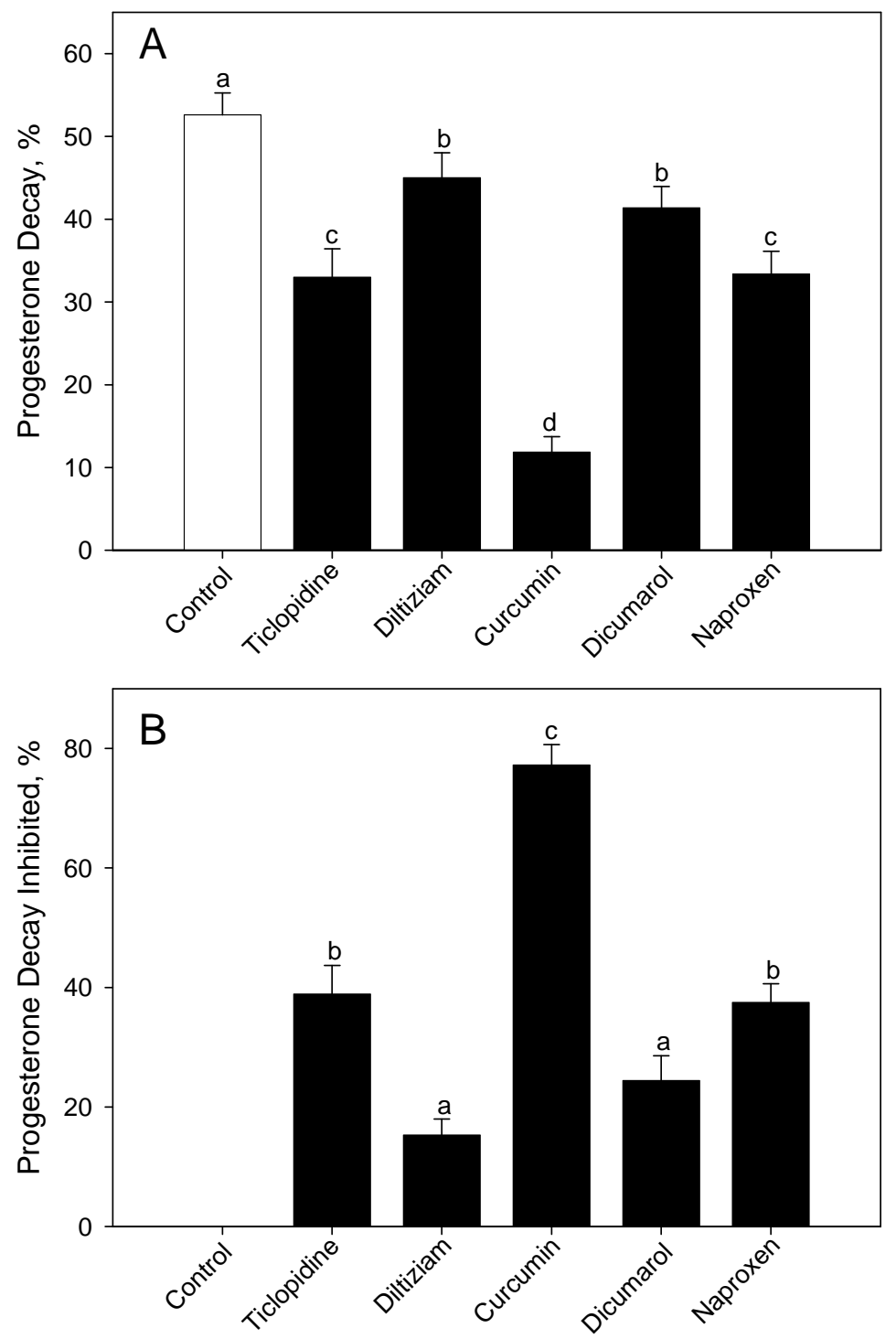

Figure 9. Progesterone decay (A) in dairy cow hepatic cell cultures after a four hour preincubation with no inhibitor (control), ticlopidine, diltiazem, curcumin, dicumarol and naproxen followed by a one hour challenge with $5 \mathrm{ng} / \mathrm{ml}$ progesterone plus inhibitor. Percent progesterone decay inhibited (B) compared to control cells preincubated with no inhibitor. Data are represented as mean \pm SEM, and different letters depict treatment differences $(P<0.05)$. 
Similar to the preliminary experiments, treatment with $20 \mu \mathrm{M}$ curcumin inhibited progesterone decay by $77 \%$ (Figure 9B). Ticlopidine or naproxen treatment inhibited progesterone decay by $\sim 40 \%$ compared to control cells, while diltiziam or dicumarol treatment inhibited progesterone decay by $15 \%$ or $23 \%$, respectively (Figure $9 \mathrm{~B}$ ).

\section{Metabolism of 4-nitrophenol and phenol red in intact cells}

Hydroxylation of 4-nitrophenol to 4-nitrocatechol was inhibited by $\sim 65 \%$ in cells treated with ticlopidine or curcumin. Diltiziam inhibited 4-nitrocatechol formation by $45 \%$, while naproxen caused a 30\% reduction (Figure 10A). Dicumarol treatment had no effect on 4-nitrophenol hydroxylation. Glucuronidation of 4-nitrocatechol (Figure 10B) or phenol red (Figure 10C) in intact cells was not affected by treatment with ticlopidine or diltiziam. The formation of both glucuronide metabolites was inhibited by treatment with curcumin, dicumarol or naproxen (Figure 10B and C).

\section{Aldo-keto reductase and cytochrome P450 activity in cellular fractions}

Curcumin, dicumarol and naproxen treatments inhibited AKR1C activity in cytosolic preparations (Figure 11A). At either concentration curcumin or naproxen caused an average decrease in AKR1C activity by $70 \%$ or $26 \%$, respectively. An effect of inhibitor concentration was observed after treatment with ticlopidine or dicumarol (Figure 11A). AKR1C activity was inhibited by $46 \%$ after treatment with $20 \mu \mathrm{M}$ dicumarol, while $60 \mu \mathrm{M}$ dicumarol caused a $69 \%$ reduction. Cells treated with $50 \mu \mathrm{M}$ ticlopidine had similar AKR1C activity compared to controls; however, treatment with $150 \mu \mathrm{M}$ ticlopidine caused a $21 \%$ reduction in AKR1C activity. CYP2C activity was inhibited by either concentration of curcumin, with a reduction of $51 \%$ and $76 \%$ in cells 

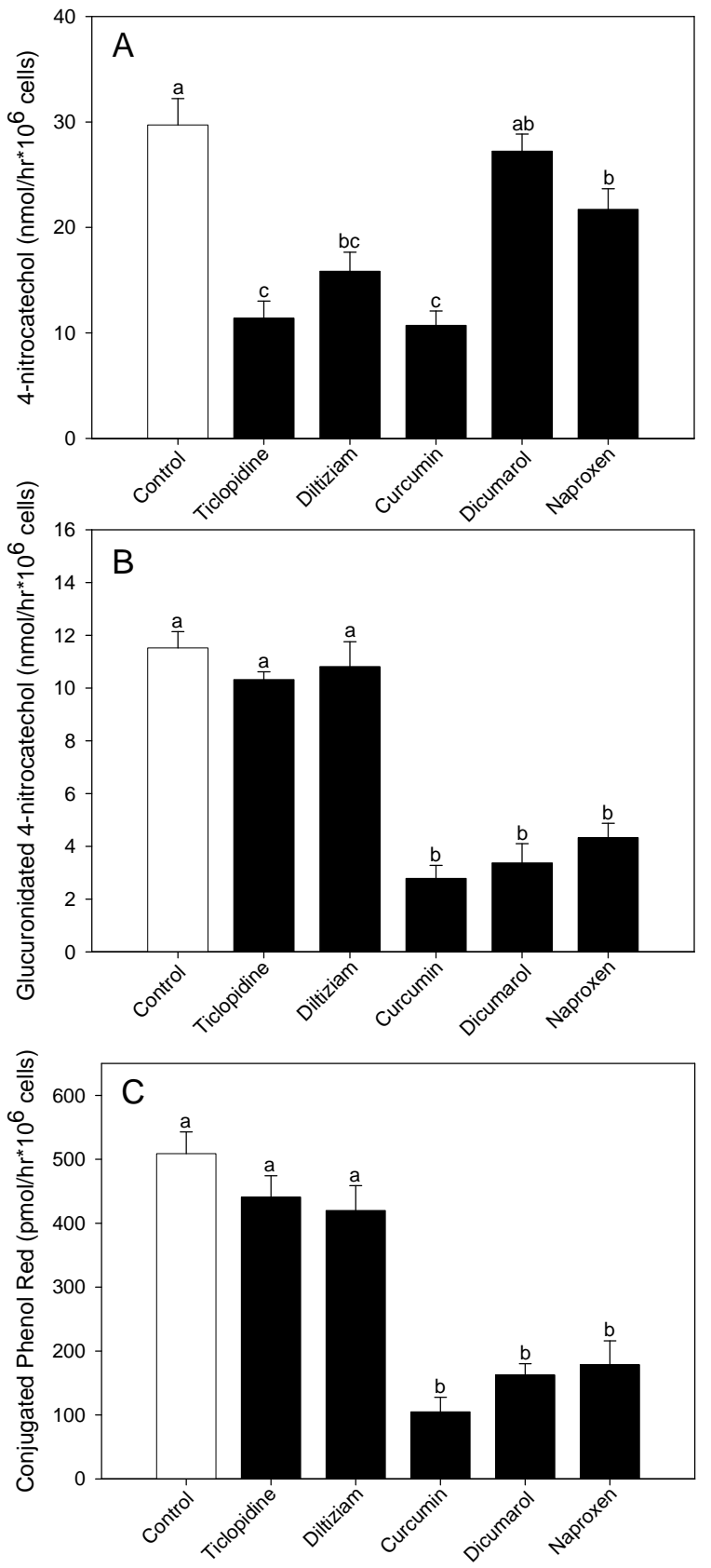

Figure 10. Four-nitrocatechol production (A), 4-nitrocatechol glucuronidation (B) and phenol red glucuronidation $(\mathrm{C})$ in dairy cow hepatic cell cultures after a four hour preincubation with no inhibitor (control), ticlopidine, diltiazem, curcumin, dicumarol and naproxen. Data are represented as mean \pm SEM, and different letters depict treatment differences $(P<0.05)$. 

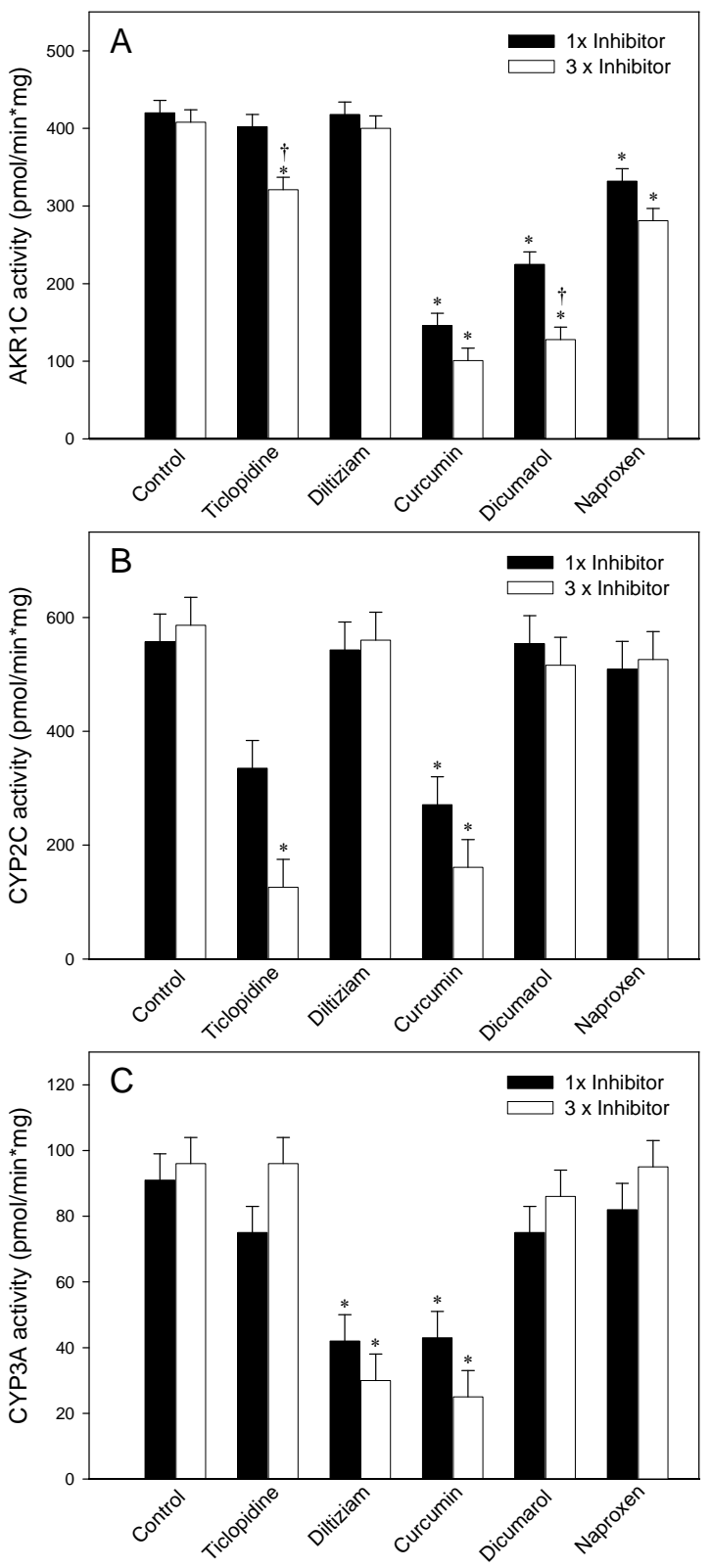

Figure 11. AKR1C (A), CYP2C (B) and CYP3A (C) activity after a 30 minute challenge with no inhibitor (control), ticlopidine, diltiazem, curcumin, dicumarol and naproxen. Values are expressed as pmol of NADP reduced per min per mg of cytosolic protein (AKR1C) or pmol of NADPH oxidized per min per mg of microsomal protein $(\mathrm{CYP} 2 \mathrm{C}$, CYP3A). Asterisk $\left(^{*}\right)$ represents a significant difference $(P<0.05)$ from controls. Cross $(\dagger)$ represents a significant difference $(P<0.05)$ within treatment due to inhibitor concentration (1x or $3 \mathrm{x}$ inhibitor concentration compared to cell culture experiments). 
treated with $20 \mu \mathrm{M}$ or $60 \mu \mathrm{M}$ curcumin, respectively (Figure 11B). The highest concentration of ticlopidine $(150 \mu \mathrm{M})$ caused a $78 \%$ reduction in CYP2C activity, while cells treated with $50 \mu \mathrm{M}$ ticlopidine had $40 \%$ lower CYP2C activity that failed to reach statistical significance compared to controls $(P=0.09$; Figure 11B). CYP3A activity was inhibited by $\sim 60 \%$ after treatment with diltiziam or curcumin (Figure 11C). Ticlopidine, dicumarol and naproxen did not affect CYP3A activity at any of the concentrations tested (Figure 11C). Microsomal cytochrome P450 reductase activity was not different between enzyme inhibitor treatments $(P=0.09)$ and averaged $9.96 \pm 0.17 \mathrm{mU} / \mathrm{mg}$ protein.

\section{Discussion}

Primary cell cultures contained a mixed population of hepatic cells with nearly $60 \%$ of the population having a fibroblast-like morphological appearance, which stained positive for actin. These populations represent nonparenchymal hepatic stellate cells, which have been shown to proliferate after injury to the liver and during non-purified cell culture experiments (Mashimo et al., 1999). Hepatocytes have been shown to deteriorate structurally and lose albumin synthesizing abilities in primary cell culture preparations (van Zijl and Mikulits, 2010). The presence of positive albumin staining represents normal hepatic function and viable hepatocytes within our culture system (Spotorno et al., 2006). Under the current culture conditions $\sim 15 \%$ of the cell population did not stain positive for actin or albumin and may represent Kupffer or endothelial cells. In addition, endothelial cells become quiescence in the presence of proliferating stellate cells (van Zijl and Mikulits, 2010), which may explain the lower percentage of cells that were not positive for either albumin or actin. 
The loses of albumin synthesis in primary hepatocyte cell cultures usually results in a concomitant decrease or no change in CYP or AKR expression and activity; furthermore, no in vitro model truly recapitulates the responses observed in vivo. In the current study, hepatic cell cultures were metabolically active and inactivating progesterone at a fast rate ( $50 \%$ after a $1 \mathrm{~h}$ exposure) in cell cultures. In addition, specific inhibitors towards CYP2C, CYP3A and AKR1C caused a decrease in progesterone inactivation. David et al. (1998) found stable protein expression and activity for CYP1A1, CYP3A4 and CYP2E1 for 4 or 5 days of experimentation in primary human hepatic cell cultures. In primary porcine hepatic cell cultures, diazepam metabolism (CYP enzymes) along with phenol red glucuronidation (UGT enzymes) were stable for 8 days of culture (Behnia et al., 2000). In the current study, metabolism of 4nitrophenol and phenol red were observed after 14 days of culture and comparable to these previous reports in human and porcine cell cultures (David et al., 1999; Behnia et al., 2000), suggesting stable expression of CYP and UGT enzymes throughout the study period. However, in 4 week old bovine hepatocyte cell cultures CYP activity, measured as 7 -ethoxycoumarin hydroxylation, decreased to $90 \%$ of 1 day old cultures (Spotorno et al., 2006). Moreover, induction or depression of these enzymes in vitro may alter the relative contributions to total progesterone decay compared to in vivo conditions.

In sheep liver microsomal preparations, CYP2C and CYP3A metabolized

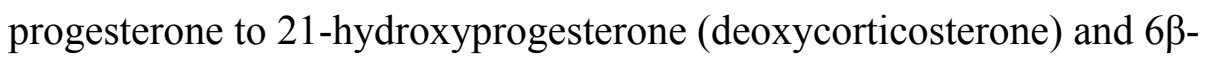
hydroxyprogesterone at a rate of $270 \mathrm{pmol} / \mathrm{min} / \mathrm{mg}$ of microsomal protein or 430 $\mathrm{pmol} / \mathrm{min} / \mathrm{mg}$ microsomal protein, respectively (Murray, 1991; 1992). The total microsomal contributions to progesterone inactivation were determined to be $\sim 25 \%$ for 
CYP2C and $\sim 55 \%$ for CYP3A in sheep. Conversely, we found a greater contribution from the CYP2C enzymes, which contributed $40 \%$ while CYP3A contributed only $15 \%$ to total progesterone inactivation in the lactating dairy cow. The higher contribution from the CYP2C inhibitor (ticlopidine) may be due to its inhibitory affects on AKR1C enzymes. In cytoplasmic preparations treated with excessive concentrations of ticlopidine we found a $21 \%$ reduction in AKR1C activity. However, similar to our observations in vitro, recent reports in the dairy cow showed a negative correlation of in vivo endogenous progesterone concentrations with CYP2C activity, while CYP3A activity was not associated with endogenous progesterone concentrations (Sá Filho et al., 2009). In addition, decreased activity of CYP2C and CYP3A has been associated with lowered progesterone clearance in dairy cows, sheep and a mouse hepatocyte cell-line (Lemley et al., 2008; 2009; 2010). However, to our knowledge no report has examined the relative contributions of each enzyme to progesterone inactivation in vitro.

The use of intact cell cultures in the current study allowed us to determine contributions from cytosolic enzymes, specifically AKR1C. In mouse liver or kidney, 20 $\alpha$-hydroxyprogesterone formation (AKR1C activity) occurred at a rate of $\sim 800$ or 400 $\mathrm{pmol} / \mathrm{min} / \mathrm{mg}$ cytosolic protein, respectively (Imamura et al., 2007). In the current study, AKR1C inhibition caused a 40\% decrease in progesterone catabolism after a 1 hour challenge with $5 \mathrm{ng} / \mathrm{ml}$ progesterone; although, the AKR1C inhibitors were not specific inhibitors because of their significant reduction in 4-nitrocatechol and phenol red glucuronidation (UGT enzyme family). The UGT enzymes are involved in the second phase of steroid biotransformation, generation of a more hydrophilic pregnandiol metabolite, which conjugate the inactive hydoxysteroid metabolites with glucuronic acid. 
UGT1A and UGT2B have been implicated in glucuronidation of hydroxylated derivatives of $\mathrm{C} 18, \mathrm{C} 19$ and $\mathrm{C} 21$ steroids (Bowalgaha et al., 2007). We originally hypothesized that inhibition of UGT enzymes would not affect the rate of progesterone catabolism, however a build up of hydroxysteroid metabolites after inhibiting UGT enzymes may lead to a lower rate of first phase progesterone biotransformation. Moreover, the $40 \%$ inhibition in progesterone decay after treating cells with an AKR1C inhibitor may be a result of decreased glucuronidation in these cultures.

Emmison et al. (1991) observed significant metabolic differences in lactating versus non-lactating sheep hepatocyte cultures challenged with growth hormone and insulin. The current study focused on progesterone decay in early lactation dairy cows, which cannot be extrapolated from previous studies in human, pig or mouse. Szotakova et al. (2004) examined protein expression and activity for CYP, AKR and UGT enzymes in pig, cattle, goat and sheep. Interspecies differences in CYP and AKR activity were found for all of the species tested. The conjugation of 4-nitrophenol (UGT activity) was highest in ovine microsomes and similar between carpine, bovine and porcine (Szotakova et al., 2004). From these studies, Szotakova et al. (2004) concluded that biotransformation of veterinary pharmaceuticals in domesticated species should be consistently tested on target species and not extrapolated from one species to another. Giantin et al. (2008) examined expression and activity for CYP and UGT enzymes in males of three different breeds of cattle (Charolais, Piedmontese and Blonde d'Aquitaine). Although, similar activities were observed across the different breeds, significant post-translational modifications within breeds were observed, including the largest discrepancy in CYP mRNA expression and CYP activity in Charolais cattle 
(Giantin et al., 2008). In the rat, hepatic protein expression and CYP activity were consistently lower in pregnant versus non-pregnant age matched controls (Dean and Stock, 1975; He et al., 2005). The differences in enzyme expression across species, breed and physiological state (pregnant, cycling or lactating) illustrates a necessity for more studies in the lactating Holstein, which could be drastically different from common laboratory species, other breeds of cattle or non-lactating cows.

\section{Conclusions}

Several studies have focused on progesterone production during the estrous cycle and various cellular mechanisms and models have been elucidated in controlling luteal function (Niswender et al., 2000; Schams and Berisha, 2004), while a paucity of information exists on the relative contributions of $\mathrm{CYP}$ and $\mathrm{AKR}$ to total progesterone inactivation. Rhinehart et al. (2009) found a greater contribution of steroid inactivation to the total concentrations of peripheral progesterone in the pregnant lactating dairy cow. Recently, our laboratory showed a tendency for a longer half-life of progesterone in dairy cows fed an insulin stimulating diet that decreased the activity of CYP2C and CYP3A (Lemley et al., 2010). From the current data set, we conclude that the enzymes CYP2C, $\mathrm{AKR} 1 \mathrm{C}$ and $\mathrm{CYP} 3 \mathrm{~A}$ are the major contributors to hepatic inactivation of progesterone in the lactating dairy cow (in order of highest to lowest activity). We could not distinguish between AKR1C and UGT enzymes due to similar inhibition and future work elucidating the specific isozymes in the dairy cow could lead to a better understanding of these pathways. Moreover, determining the specific isozymes and their contributions to steroid clearance will allow researchers to characterize these pathways during various physiological states in vivo. 


\section{References}

Anzenbacher, P. and E. Anzenbacherova. 2001. Cytochrome P450 and metabolism of xenobiotics. Cell. Mol. Life Sci. 58:737-747.

Barski, O. A., S. M. Tipparaju, and A. Bhatnagar. 2008. The aldo-keto reductase superfamily and its role in drug metabolism and detoxification. Drug Metab. Rev. 40:553-624.

Basu, N. K., M. Kovarova, A. Garza, S. Kubota, T. Saha, P. S. Mitra, R. Banerjee, J. Rivera, and I. S. Owens. 2005. Phosphorylation of a UDP-glucuronosyltransferase regulates substrate specificity. Proceedings of the National Academy of Sciences. 102:6285-6290.

Behnia, K., S. Bhatia, N. Jastromb, U. Balis, S. Sullivan, M. Yarmush, and M. Toner. 2000. Xenobiotic metabolism by cultured primary porcine hepatocytes. Tissue Engineering. 6:467-479.

Bowalgaha, K., D. J. Elliot, P. I. Mackenzie, K. M. Knights, and J. O. Miners. 2007. The glucuronidation of $\Delta^{4}$-3-keto C19-and C21-hydroxysteroids by human liver microsomal and recombinant UDP-glucuronosyltransferases (UGTs): $6 \alpha$ and 21 hydroxyprogesteorne are selective substrates for UGT2B7. Drug Metabolism and Disposition. 35:363-370.

Chagas, L. M., J. J. Bass, D. Blache, C. R. Burke, J. K. Kay, D. R. Lindsay, M. C. Lucy, G. B. Martin, S. Meier, F. M. Rhodes, J. R. Roche, W. W. Thatcher, and R. Webb. 2007. Invited review: New perspectives on the roles of nutrition and metabolic priorities in the subfertility of high-producing dairy cows. J. Dairy Sci. 90:4022-4032.

David, P., C. Viollon, E. Alexandre, A. Azimzadeh, L. Nicod, P. Wolf, D. Jaech, K. Boudjema, and L. Richert. 1998. Metabolic capacities in cultured human hepatocytes obtained by a new isolating procedure from non-wedge small liver biopsies. Human and Experimental Toxicology. 17:544-553.

Dean, M. E. and B. H. Stock. 1975. Hepatic microsomal metabolism of drugs during pregnancy in the rat. Drug Metabolism and Disposition. 3:325-331.

Emmison, N., L. Agius and V. A. Zammit. 1991. Regulation of fatty acid metabolism and gluconeogenesis by growth hormone and insulin in sheep hepatocyte cultures. Biochem. J. 274:21-26.

Giantin, M., M. Carletti, F. Capolongo, S. Pegolo, R. M. Lopparelli, F. Gusson, C. Nebbia, M. Canteillo, P. Martin, T. Pineau, and M. Dacasto. Effect of breed upon cytochromes P450 and phase II enzyme expression in cattle liver. Drug Metabolism and Disposition. 36:885-893. 
Hawkins, D. E., K. D. Niswender, G. M. Oss, C. L. Moeller, K. G. Odde, H. R. Sawyer, and G. D. Niswender. 1995. An increase in serum lipids increases luteal lipid content and alters the disappearance rate of progesterone in cows. J. Anim. Sci. 73:541-545.

He, J. H., N. Ejiri, H. Nakayama, and K. Doi. 2005. Effects of pregnancy on CYPs protein expression in rat liver. Experimental and Molecular Pathology. 78:64-70.

Imamura, Y., M. Ohtaguro, and H. Shimada. 2007. Several distinct enzymes catalyze $20 \alpha$-hydroxysteroid dehydrogenase activity in mouse liver and kidney. Journal of Steroid Biochemistry and Molecular Biology. 107:120-126.

Jones, D. R., J. C. Gorski, M. A. Hamman, B. S. Mayhew, S. Rider, and S. D. Hall. 1999. Diltiazem inhibition of cytochrome P-450 3A activity is due to metabolite intermediate complex formation. Journal of Pharmacology and Experimental Therapeutics. 290:1116-1125.

Kabututu, Z., M. Manin, J. C. Pointud, T. Maruyama, N. Nagata, S. Lambert, A. M. Lefrancois-Martinez, A. Martinez, and Y. Urade. 2009. Prostaglandin F2alpha synthase activites of aldo-keto reductase 1B1, 1B3 and 1B7. J. Biochem. 145:161168.

Ko, W. J., Z. Desta, N. V. Soukhova, T. Tracy, and D. A. Flockhart. 2000. In vitro inhibition of the cytochrome P450 (CYP450) system by the antiplatelet drug ticlopidine: potent effect on CYP2C19 and CYP2D6. Br. J. Clin. Pharmacol. 49:343-351.

Lemley, C. O., J. M. Koch, K. P. Blemings, K. M. Krause, and M. E. Wilson. 2008. Concomitant changes in progesterone catabolic enzymes, cytochrome P450 2C and $3 \mathrm{~A}$, with plasma insulin concentrations in ewes supplemented with sodium acetate or sodium propionate. Animal. 2:1223-1229.

Lemley, C. O., J. M. Koch, K. P. Blemings, and M. E. Wilson. 2009. Alterations in progesterone catabolic enzymes, CYP2C and CYP3A, in hepatocytes challenged with insulin and glucagon. Journal of Animal and Veterinary Advances. 8:39-46.

Lemley, C. O., T. A. Wilmoth, L. R. Tager, K. M. Krause, and M. E. Wilson. 2010. Effect of a high cornstarch diet on hepatic cytochrome P450 2C and 3A activity and progesterone half-life in dairy cows. Journal of Dairy Science. 93:1012-1021.

Leroy, J. L. M. R., A. Van Soom, G. Opsomer, I. G. F. Goovaerts, and P. E. J. Bols. 2008. Reduced fertility in high-yielding dairy cows: Are the oocyte and embryo in danger? Part II. Reprod. Dom. Anim. 43:623-632. 
Mashimo, Y., S. Mochida, M. Inao, M. Yamaoka, S. Nagoshi, A. Matsui, and K. Fujiwara. 1999. Decreased expression of smooth muscle $\alpha$ actin in activated rat hepatic stellate cells at the S-phase of the cell cycle in vitro. Hepatology Research. 15:22-31.

Miller, H. M., G. R. Foxcroft, J. Squires, and F. X. Aherne. 1999. The effects of feed intake and body fatness on progesterone metabolism in ovariectomized gilts. J. Anim. Sci. 77:3253-3261.

Monostory, K., E. Hazai, and L. Vereczkey. 2004. Inhibition of cytochrome P450 enzymes participating in p-nitrophenol hydroxylation by drugs known as CYP2E1 inhibitors. Chemico-Biological Interactions. 147:331-340.

Murray, M. 1991. Microsomal cytochrome P450-dependent steroid metabolism in male sheep liver. Quantitative importance of $6 \beta$-hydroxylation and evidence for the involvement of a P450 from the IIIA subfamily in the pathway. J. Steroid Biochem. Molec. Biol. 38:611-619.

Murray, M. 1992. Participation of a cytochrome P450 enzyme from the 2C subfamily in progesterone 21-hydroxylation in sheep liver. J. Steroid Biochem. Molec. Biol. 43:591-593.

Nelson, A. C., W. Huang, and D. E. Moody. 2001. Variables in human liver microsome preparation: Impact on the kinetics of L-alpha-acetylmethadol (LAAM) Ndemethylation and dextromethorphan O-demethylation. Drug Metabolism and Disposition. 29:319-325.

Niswender, G. D., J. L. Juengel, P. J. Silva, M. K. Rollyson, and E. W. McIntush. 2000. Mechanisms controlling the function and life span of the corpus luteum. Physiol. Rev. 80:1-29.

Palackal N. T., S. H. Lee, R. G. Harvey, I. A. Blair, and T. M. Penning. 2002. Activation of polycyclic aromatic hydrocarbon trans-dihydrodiol proximate carcinogens by human aldo-keto reductase (AKR1C) enzymes and their functional overexpression in human lung carcinoma (A549) cells. J. Biol Chem. 277:2479924808

Parr, R. A., I. F. Davis, M. A. Miles, and T. J. Squires. 1993. Liver blood flow and metabolic clearance rate of progesterone in sheep. Res. Vet. Sci. 55:311-316.

Penning, T. M., M. E. Burczynski, J. M. Jez, C. Hung, H. Lin, H. Ma, M. Moore, N. Palackal, and K. Ratnam. 2000. Human 3 $\alpha$-hydroxysteroid dehydrogenase isoforms (AKR1C1-AKR1C4) of the aldo-keto reductase superfamily: functional plasticity and tissue distribution reveals roles in the inactivation and formation of male and female sex hormones. Biochem. J. 351:67-77. 
Reinke, L. A. and M. J. Moyer. 1985. p-nitrophenol hydroxylation: A microsomal oxidation which is highly inducible by ethanol. Drug Metabolism and Disposition. 13:548:552.

Rhinehart, J. D., M. J. Starbuck-Clemmer, J. A. Flores, R. A. Milvae, J. Yao, D. H. Poole, and E. K. Inskeep. 2009. Low peripheral progesterone and late embryonic/early fetal loss in suckled beef and lactating dairy cows. Theriogenology. 71:480-490.

Sá Filho O. G., C. O. Lemley, M. E. Wilson, J. Hillegass, J. L. M. Vasconcelos, and W. R. Butler. 2009. Relationships between dry matter intake (DMI), plasma progesterone ( $\mathrm{P} 4)$, and liver catabolic enzymes in lactating dairy cows. Journal of Animal Science. 87(Suppt 2):M229. (Abstr.).

Sangsritavong, S., D. K. Combs, R. Sartori, L. E. Armentano, and M. C. Wiltbank. 2002. High feed intake increases liver blood flow and metabolism of progesterone and estradiol-17 $\beta$ in dairy cattle. J. Dairy Sci. 85:2831-2842.

Savlik M., L. Polackova, B. Szotakova, J. Lamka, J. Velik, and L. Skalova. 2007. Activities of biotransformation enzymes in pheasant (Phasianus colchicus) and their modulation by in vivo administration of mebendazole and flubendazole. Research in Veterinary Science. 83:20-26.

Schams, D. and B. Berisha. 2004. Regulation of corpus luteum function in cattle-an overview. Reprod. Dom. Anim. 39:241-251.

Segura-Aguilar, J. E., V. Barreiro, and C. Lind. Dicoumarol-sensitive glucuronidation of benzo(a)pyrene metabolites in rat liver microsomes. Arch. Biochem. Biophys. 251:266-275.

Sheffel, C. E., B. R. Pratt, W. L. Ferrell, and E. K. Inskeep. 1982. Induced corpora lutea in the postpartum beef cow. II. Effects of treatment with progestogen and gonadotropins. Journal of Animal Science. 54:830-836.

Spotorno, V. G., A. Hidalgo, M. Barbich, A. Lorenti, and O. Zabal. 2006. Culture of bovine hepatocytes: a non-perfusion technique for cell isolation. Cytotechnology. 51:51-56.

Swanson, K. S., N. R. Merchen, J. W. Erdman, Jr, J. K. Drackley, F. Orias, G. N. Douglas, and J. C. Huhn. 2000. Technical note: a technique for multiple liver biopsies in neonatal calves. J. Anim. Sci. 78:2459-2463.

Szotakova, B., V. Baliharova, J. Lamka, E. Nozenova, V. Wsol, J. Velik, M. Machala, J. Neca, P. Soucek, S. Susova, and L. Skolova. 2004. Comparison of in vitro activites of biotransformation enzymes in pig, cattle, goat and sheep. Research in Veterinary Science. 76:43-51. 
Thomford, P. J. and P. J. Dziuk. 1986. The influence of dose of phenobarbital and interval to measurement on concentration of liver enzymes in barrows and gilts. J. Anim. Sci. 63:1184-1190.

van Zijl, F. and W. Mikulits. 2010. Hepatospheres: Three dimensional cell cultures resemble physiological conditions of the liver. World J. Hepatol. 27:1-7.

Volak, L. P., S. Ghirmai, J. R. Cashman, and M. H. Court. 2008. Curcuminoids inhibit multible human cytochromes P450 (CYP), UDP-glucuronosyltransferase (UGT), and sulfotransferase (SULT) enzymes, while piperine is a relatively selective CYP3A4 inhibitor. Drug Metab. Dispos. 36:1594-1605.

Waxman, D. J., D. P. Lapenson, T. Aoyama, H. V. Gelboin, F. J. Gonzalez, and K. Korzekwa. 1991. Steroid hormone hydroxylase specificites of eleven cDNAexpressed human cytochrome P450s. Archives of Biochemistry and Biophysics. 290:160-166.

Yee, D. J., V. Balsanek, D. R. Bauman, T. M. Penning, and D. Sames. 2006. Fluorogenic metabolic probes for direct activity readout of redox enzymes: Selective measurement of human AKR1C2 in living cells. Proceedings of the National Academy of Sciences. 103:13304-13309.

Zerilli, A., D. Ratanasavanh, D. Lucas, T. Goasduff, Y. Dreano, C. Menard, D. Picart, and F. Berthou. 1997. Both cytochromes P4502E1 and 3A are involved in the Ohydroxyltaion of p-nitrophenol, a catalytic activity known to be specific for P4502E1. Chem. Res. Toxicol. 10:1205-1212. 


\section{GENERAL DISCUSSION}

Pregnancy loss continues to be a major economic concern to the dairy industry and alleviating pregnancy wastage would improve the efficiency of all dairy operations. Several researchers have found differences in plasma concentrations of steroids during mid-luteal phase of the estrus cycle or pregnancy after varying dietary treatments or after treatment with different metabolic hormones (i.e. growth hormone and insulin); however, a substantial portion of these studies have failed to distinguish between differences due to steroid production, steroid clearance or a combination of both. In the current studies we focused on clearance of progesterone from an exogenous source in two different herds of Holstein cattle treated with the same experimental diet. In both herds of cattle dry matter intake and milk yield were not altered by dietary treatment; however, the North Dakota herd consumed more feed and had a greater milk yield compared to the West Virginia herd. In the West Virginia herd we found a trend for a longer half-life of progesterone after feeding a diet high in refined cornstarch compared to a high fiber diet. Cytochrome P450 2C activity was lower, while cytochrome P450 3A activity tended to be lower in cows consuming a high cornstarch diet versus a high fiber diet.

In the North Dakota herd liver blood flow was not different after altering energy source, while the metabolic clearance rate of progesterone tended to be lower in cows consuming the high cornstarch diet compared to the high fiber diet. The half-life of progesterone, measured at a similar time compared to the time of liver biopsy, was increased 3 fold in cows consuming the high cornstarch diet versus the high fiber diet. Similar to the West Virginia herd, the North Dakota herd had lower cytochrome P450 2C and $3 \mathrm{~A}$ activity when consuming the high cornstarch diet versus the high fiber diet. 
Feeding diets that stimulate insulin secretion may modify progesterone clearance by inhibiting hepatic activity of cytochrome P450 2C and 3A. Decreasing steroid clearance during early pregnancy may lead to higher peripheral concentrations of progesterone, which could advance embryonic development during the early period of pregnancy when embryonic loss and pregnancy wastage are high.

Several studies have focused on progesterone production during the estrous cycle and various cellular mechanisms and models have been elucidated in controlling luteal function, while a paucity of information exists on the relative contributions of CYP and AKR to total progesterone biotransformation. Peripheral progesterone concentrations in the pregnant lactating dairy cow may be under greater control from steroid inactivation versus steroid production. In order to advance the observations from the in vivo studies we wanted to determine the relative contributions of CYP and AKR to total progesterone biotransformation in the lactating dairy cow. From the current data set we conclude that the enzymes CYP2C, AKR1C and CYP3A are the major contributors to hepatic inactivation of progesterone in the lactating dairy cow (in order of highest to lowest activity). We could not distinguish between AKR1C and UGT enzymes due to similar inhibition and future work elucidating the specific isozymes in the dairy cow could lead to a better understanding of these pathways. Moreover, determining the specific isozymes and their contributions to steroid clearance will allow researchers to characterize these pathways during various physiological states in vivo. 


\section{LITERATURE CITED}

Anzenbacher, P. and E. Anzenbacherova. 2001. Cytochrome P450 and metabolism of xenobiotics. Cell. Mol. Life Sci. 58:737-747.

Association of Official Analytical Chemists. 1995. Official Methods of Analysis. Vol I. $15^{\text {th }}$ ed. AOAC, Arlington, Va.

Barnnett, C. R., G. G. Gibson, C. R. Wolf, P. R. Flatt, and C. Ioannides. 1990. Induction of cytochrome P450III and P450IV family proteins in streptozotocin-induced diabetes. Biochem. J. 268:765-769.

Barski, O. A., S. M. Tipparaju, and A. Bhatnagar. 2008. The aldo-keto reductase superfamily and its role in drug metabolism and detoxification. Drug Metab. Rev. 40:553-624.

Basu, N. K., M. Kovarova, A. Garza, S. Kubota, T. Saha, P. S. Mitra, R. Banerjee, J. Rivera, and I. S. Owens. 2005. Phosphorylation of a UDP-glucuronosyltransferase regulates substrate specificity. Proceedings of the National Academy of Sciences. 102:6285-6290.

Bedford, C. A., F. A. Harrison, and F. B. Heap. 1972. The metabolic clearance rate and production rate of progesterone and the conversion of progesterone to 20-alphahydroxypregn-4-en-3-one in the sheep. J. Endocrinol. 55:105-118.

Bedford, C. A., F. A. Harrison, and F. B. Heap. 1974. Splanchnic, uterine, ovarian and adrenal uptake of progesterone and 20-alpha-hydroxyprogesterone in the pregnant and non-pregnant sheep. J. Endocrinol. 62:277-290.

Behnia, K., S. Bhatia, N. Jastromb, U. Balis, S. Sullivan, M. Yarmush, and M. Toner. 2000. Xenobiotic metabolism by cultured primary porcine hepatocytes. Tissue Engineering. 6:467-479.

Berry, L. A. and P. Skett. 1988. The role of cyclic-AMP in the regulation of steroid metabolism in isolated rat hepatocytes. Biochem. Pharmacol. 37:2411-2416.

Bowalgaha, K., D. J. Elliot, P. I. Mackenzie, K. M. Knights, and J. O. Miners. 2007. The glucuronidation of $\Delta^{4}$-3-keto C19-and C21-hydroxysteroids by human liver microsomal and recombinant UDP-glucuronosyltransferases (UGTs): $6 \alpha$ and 21 hydroxyprogesteorne are selective substrates for UGT2B7. Drug Metabolism and Disposition. 35:363-370.

Bridges, P. J., D. J. Wright, W. I. Buford, N. Ahmad, H. Hernandez-Fonseca, M. L. McCormick, F. N. Schrick, R. A. Dailey, P. E. Lewis and E. K. Inskeep. 2000. Ability of induced corpora lutea to maintain pregnancy in beef cows. J. Anim. Sci. 78:2942-2949. 
Butcher, R. L. 1977. Changes in gonadotropins and steroids associated with unilateral ovariectomy of the rat. Endocrinology. 101:830-840.

Butler, S. T., S. H. Pelton, and W. R. Butler. 2004. Insulin increases $17 \beta$-estradiol production by the dominant follicle of the first post-partum follicle wave in dairy cows. Reproduction. 127:537-545.

Chagas, L. M., J. J. Bass, D. Blache, C. R. Burke, J. K. Kay, D. R. Lindsay, M. C. Lucy, G. B. Martin, S. Meier, F. M. Rhodes, J. R. Roche, W. W. Thatcher, and R. Webb. 2007. Invited review: New perspectives on the roles of nutrition and metabolic priorities in the subfertility of high-producing dairy cows. J. Dairy Sci. 90:4022-4032.

Christenson, L. K. and L. Devoto. 2003. Cholesterol transport and steroidogenesis by the corpus luteum. Reproductive Biology and Endocrinology. 1:90.

Costine, B. A., E. K. Inskeep, K. P. Blemings, J. A. Flores, and M. E. Wilson. 2007. Mechanisms of reduced luteal sensitivity to prostaglandin F2alpha during maternal recognition of pregnancy in ewes. Domest. Anim. Endocrinol. 32:106121.

Csapo, A. 1956. Progesterone block. Am. J. Anat. 98:273-292.

Cunningham, K. D., M. J. Cecava, and T. R. Johnson. 1993. Nutrient digestion, nitrogen and amino acid flows in lactating cows fed soybean hulls in place of forage or concentrate. J. Dairy Sci. 76:3523-3535.

David, P., C. Viollon, E. Alexandre, A. Azimzadeh, L. Nicod, P. Wolf, D. Jaech, K. Boudjema, and L. Richert. 1998. Metabolic capacities in cultured human hepatocytes obtained by a new isolating procedure from non-wedge small liver biopsies. Human and Experimental Toxicology. 17:544-553.

De Vries, A. 2006. Economic value of pregnancy in dairy cattle. J. Dairy Sci. 89-38763885.

Dean, M. E. and B. H. Stock. 1975. Hepatic microsomal metabolism of drugs during pregnancy in the rat. Drug Metabolism and Disposition. 3:325-331.

Deriaz, R. E. 1961. Routine analysis of carbohydrates and lignin in herbage. J. Sci. Food Agri. 12:152-160.

Einer-Jenson N. and R. H. F. Hunter. 2000. Physiological and pharmacological aspects of local transfer of substances in the ovarian adnexa in women. Human Reproduction Update. 6:132-138. 
Einer-Jenson N. and R. H. F. Hunter. 2005. Counter-current transfer in reproductive biology. Reproduction. 129: 9-18.

Emmison, N., L. Agius and V. A. Zammit. 1991. Regulation of fatty acid metabolism and gluconeogenesis by growth hormone and insulin in sheep hepatocyte cultures. Biochem. J. 274:21-26.

Erb, R. E., V. L. Estergreen, Jr., W. R. Gomes, E. D. Plotka, and O. L. Frost. 1967. Progestin content of ovaries and the effect on assessment of luteal activity in the bovine. Journal of Dairy Science. 51:411-415.

Garfield, R. E., S. Sims, and E. E. Daniel. 1977. Gap junctions: Their presence and necessity in myometrium during parturition. Science. 198:958-960.

Garfield, R. E., S. M. Sims, M. S. Kannan, and E. E. Daniel. 1978. Possible role of gap junctions in activation of myometrium during parturition. Am. J. Physiol. 235:168-179.

Garnsworthy, P. C., A. Lock, G. E. Mann, K. D. Sinclair, and R. Webb. 2008a. Nutrition, metabolism, and fertility in dairy cows: 1. dietary energy source and ovarian function. J. Dairy Sci. 91:3814-3823.

Garnsworthy, P. C., A. Lock, G. E. Mann, K. D. Sinclair, and R. Webb. 2008b. Nutrition, Metabolism, and fertility in dairy cows: 2 . dietary fatty acids and ovarian function. J. Dairy Sci. 91:3824-3833.

Garnsworthy, P. C., A. A. Fouladi-Nashta, G. E. Mann, K. D. Sinclair, and R. Webb. 2009. Effect of dietary-induced changes in plasma insulin concentrations during the early post partum period on pregnancy rate in dairy cows. Reproduction. 137:759-768.

Giantin, M., M. Carletti, F. Capolongo, S. Pegolo, R. M. Lopparelli, F. Gusson, C. Nebbia, M. Canteillo, P. Martin, T. Pineau, and M. Dacasto. Effect of breed upon cytochromes P450 and phase II enzyme expression in cattle liver. Drug Metabolism and Disposition. 36:885-893.

Ginther, O. J. 1974. Internal regulation of physiological processes through local venoarterial pathways: a review. Journal of Animal Science. 39:550-564.

Gomes, W. R., V. L. Estergreen, Jr., O. L. Frost, and R. E. Erb. 1963. Progestin levels in jugular and ovarian venous blood, corpora lutea, and ovaries of the nonpregnant bovine. Journal of Dairy Science. 46:553-558.

Gong, J. G., W. J. Lee, P. C. Grarnsworthy, and R. Weeb. 2002. Effect of dietary-induced increases in circulating insulin concentrations during the early postpartum period on reproductive function in dairy cows. Reproduction. 123:419-427. 
Gorski, J., R. E. Erb, W. M. Dickson, and H. C. Butler. 1958. Sources of progestins in the pregnant cow. Journal of Dairy Science. 41:1380-1386.

Graham, J. D. and C. L. Clarke. 1997. Physiological action of progesterone in target tissues. Endocrine Reviews. 18:502-519.

Green, M. P., M. G. Hunter, and G. E. Mann. 2005. Relationship between maternal hormone secretion and embryo development on day 5 of pregnancy in dairy cows. Animal Reproduction Sciences. 88:179-189.

Gurpide, E. Tracer Methods in Hormone Research: Monographs on Endocrinology Springer-Verlag New York. 1975.

Hawkins, D. E., K. D. Niswender, G. M. Oss, C. L. Moeller, K. G. Odde, H. R. Sawyer, and G. D. Niswender. 1995. An increase in serum lipids increases luteal lipid content and alters the disappearance rate of progesterone in cows. J. Anim. Sci. 73:541-545.

He, J. H., N. Ejiri, H. Nakayama, and K. Doi. 2005. Effects of pregnancy on CYPs protein expression in rat liver. Experimental and Molecular Pathology. 78:64-70.

Hidalgo, C. O., E. Gomez, L. Prieto, P. Duque, F. Goyache, L. Fernandez, I. Fernandez, N. Facal, and C. Diez. 2004. Pregnancy rates and metabolic profiles in cattle treated with propylene glycol prior to embryo transfer. Theriogenology. 62:664676.

Hirsbrunner, G., B. Knutti, I. Liu, U. Kupfer, G. Scholtysik, and A. Steiner. 2002. An in vitro study on spontaneous myometrial contractility in the cow during estrus and diestrus. Animal Reproduction Science. 70:171-180.

Imamura, Y., M. Ohtaguro, and H. Shimada. 2007. Several distinct enzymes catalyze $20 \alpha$-hydroxysteroid dehydrogenase activity in mouse liver and kidney. Journal of Steroid Biochemistry and Molecular Biology. 107:120-126.

Inskeep, E. K. and R. A. Dailey. 2005. Embryonic death in cattle. Vet. Clin. Food Anim. 21:437-461.

Jones, D. R., J. C. Gorski, M. A. Hamman, B. S. Mayhew, S. Rider, and S. D. Hall. 1999. Diltiazem inhibition of cytochrome P-450 3A activity is due to metabolite intermediate complex formation. Journal of Pharmacology and Experimental Therapeutics. 290:1116-1125.

Kabututu, Z., M. Manin, J. C. Pointud, T. Maruyama, N. Nagata, S. Lambert, A. M. Lefrancois-Martinez, A. Martinez, and Y. Urade. 2009. Prostaglandin F2alpha 
synthase activites of aldo-keto reductase 1B1, 1B3 and 1B7. J. Biochem. 145:161168.

Kijas, J. W., M. Menzies, and A. Ingham. 2006. Sequence diversity and rates of molecular evolution between sheep and cattle genes. Anim. Genet. 37:171-174.

Ko, W. J., Z. Desta, N. V. Soukhova, T. Tracy, and D. A. Flockhart. 2000. In vitro inhibition of the cytochrome P450 (CYP450) system by the antiplatelet drug ticlopidine: potent effect on CYP2C19 and CYP2D6. Br. J. Clin. Pharmacol. 49:343-351.

Koch, J. M. 2008. Periconceptional treatment with growth hormone alters fetal growth and development in sheep. Dissertation, West Virginia University.

Larson, S. F., W. R. Butler, and W. B. Currie. 2007. Pregnancy rates in lactating dairy cattle following supplementation of progesterone after artificial insemination. Anim. Reprod. Sci. 102:172-179.

Lemley, C. O., J. M. Koch, K. P. Blemings, K. M. Krause, and M. E. Wilson. 2008a. Concomitant changes in progesterone catabolic enzymes, cytochrome P450 2C and 3A, with plasma insulin concentrations in ewes supplemented with sodium acetate or sodium propionate. Animal. 2:1223-1229.

Lemley, C. O., S. T. Butler, W. R. Butler, and M. E. Wilson. 2008b. Short communication: insulin alters hepatic progesterone catabolic enzymes, cytochrome P450 2C and 3A, in dairy cows. J. Dairy Sci. 91:641-645.

Lemley, C. O., J. M. Koch, K. P. Blemings, and M. E. Wilson. 2009. Alterations in progesterone catabolic enzymes, CYP2C and CYP3A, in hepatocytes challenged with insulin and glucagon. J. Anim. Vet. Adv. 8:39-46.

Lemley, C. O., T. A. Wilmoth, L. R. Tager, K. M. Krause, and M. E. Wilson. 2010. Effect of a high cornstarch diet on hepatic cytochrome P450 2C and 3A activity and progesterone half-life in dairy cows. Journal of Dairy Science. 93:1012-1021.

Leroy, J. L. M. R., A. Van Soom, G. Opsomer, I. G. F. Goovaerts, and P. E. J. Bols. 2008. Reduced fertility in high-yielding dairy cows: Are the oocyte and embryo in danger? Part II. Reprod. Dom. Anim. 43:623-632.

Mann, G. E., M. P. Green, K. D. Sinclair, K. J. Demmers, M. D. Fray, C. G. Gutierrez, P. C. Garnsworthy, and R. Weeb. 2003. Effects of circulating progesterone and insulin on early embryo development in beef heifers. Anim. Reprod. Sci. 79:7179.

Mann, G. E. and G. E. Lamming. 1999. The influence of progesterone during early pregnancy in cattle. Reprod. Dom. Anim. 34:269-274. 
Mann, G. E., M. D. Fray, and G. E. Lamming. 2006. Effects of time on progesterone supplementation on embryo development and interferon-tau production in the cow. The Veterinary Journal. 171:500-503.

Mansfield, H. R. and M. D. Stern. 1994. Effects of soybean hulls and lignosulfonatetreated soybean meal on rumen fermentation in lactating dairy cows. J. Dairy Sci. 77:1070-1083.

Mashimo, Y., S. Mochida, M. Inao, M. Yamaoka, S. Nagoshi, A. Matsui, and K. Fujiwara. 1999. Decreased expression of smooth muscle $\alpha$ actin in activated rat hepatic stellate cells at the S-phase of the cell cycle in vitro. Hepatology Research. 15:22-31.

McDonald, L. E., R. E. Nichols, and S. H. McNutt. 1952. Studies on corpus luteum ablation and progesterone replacement therapy during pregnancy in the cow. Am. J. Vet. Res. 13:446-451.

Mesiano, S. 2007. Myometrial progesterone responsiveness. Seminars in Reproductive Medicine. 25:5-13.

Miller, W. R., R. Williams, G. W. Pipes, and C. W. Turner. 1963. Conjugation, distribution, and biological half-life of radioactive progesterone in plasma and red cells of bovine blood. Journal of Dairy Science. 46:1402-1404.

Miller, H. M., G. R. Foxcroft, J. Squires, and F. X. Aherne. 1999. The effects of feed intake and body fatness on progesterone metabolism in ovariectomized gilts. J. Anim. Sci. 77:3253-3261.

Miyoshi, S., J. L. Pate, and D. L. Palmquist. 2001. Effects of propylene glycol drenching on energy balance, plasma glucose, plasma insulin, ovarian function and conception in dairy cows. Anim. Reprod. Sci. 68:29-43.

Monostory, K., E. Hazai, and L. Vereczkey. 2004. Inhibition of cytochrome P450 enzymes participating in p-nitrophenol hydroxylation by drugs known as CYP2E1 inhibitors. Chemico-Biological Interactions. 147:331-340.

Moriel, P., T. S. Scatena, O. G. Sa Filho, R. F. Cooke, and J. L. M. Vasconcelos. 2008. Concentrations of progesterone and insulin in serum of nonlactating dairy cows in response to carbohydrate source and processing. J. Dairy Sci. 91:4616-4621.

Murray, M. 1991. Microsomal cytochrome P450-dependent steroid metabolism in male sheep liver. Quantitative importance of $6 \beta$-hydroxylation and evidence for the involvement of a P450 from the IIIA subfamily in the pathway. J. Steroid Biochem. Molec. Biol. 38:611-619. 
Murray, M. 1992. Participation of a cytochrome P450 enzyme from the 2C subfamily in progesterone 21-hydroxylation in sheep liver. J. Steroid Biochem. Molec. Biol. 43:591-593.

National Research Council. 2001. Nutrient Requirements of Dairy Cattle. $7^{\text {th }}$ rev. ed. Natl. Acad. Press, Washington, DC.

Nelson, A. C., W. Huang, and D. E. Moody. 2001. Variables in human liver microsome preparation: Impact on the kinetics of L-alpha-acetylmethadol (LAAM) Ndemethylation and dextromethorphan O-demethylation. Drug Metab. Dispos. 29:319-325.

Niswender, G. D., J. L. Juengel, P. J. Silva, M. K. Rollyson, and E. W. McIntush. 2000. Mechanisms controlling the function and life span of the corpus luteum. Physiol. Rev. 80:1-29.

Orsino A, C. V. Taylor and S. J. Lye. 1996. Connexin-26 and connexin-43 are differentially expressed and regulated in the rat myometrium throughout late pregnancy and with the onset of labor. Endocrinol. 137:1545-1553.

Palackal, N. T., S. H. Lee, R. G. Harvey, I. A. Blair, and T. M. Penning. 2002. Activation of polycyclic aromatic hydrocarbon trans-dihydrodiol proximate carcinogens by human aldo-keto reductase (AKR1C) enzymes and their functional overexpression in human lung carcinoma (A549) cells. J. Biol. Chem. 277:2479924808 .

Parr, R. A., I. F. Davis, M. A. Miles, and T. J. Squires. 1993a. Feed intake affects metabolic clearance rate of progesterone in sheep. Res. Vet. Sci. 55:306-310.

Parr, R. A., I. F. Davis, M. A. Miles, and T. J. Squires. 1993b. Liver blood flow and metabolic clearance rate of progesterone in sheep. Res. Vet. Sci. 55:311-316.

Penning, T. M., M. E. Burczynski, J. M. Jez, C. Hung, H. Lin, H. Ma, M. Moore, N. Palackal, and K. Ratnam. 2000. Human 3 $\alpha$-hydroxysteroid dehydrogenase isoforms (AKR1C1-AKR1C4) of the aldo-keto reductase superfamily: functional plasticity and tissue distribution reveals roles in the inactivation and formation of male and female sex hormones. Biochem. J. 351:67-77.

Penning, T. M., M. E. Burczynski, J. M. Jez, H. Lin, H. Ma, M. Moore, K. Ratnam, and N. Palackal. 2001. Structure-function aspects and inhibitor design of type $517 \beta-$ hydroxysteroid dehydrogenase (AKR1C3). Molecular and Cellular Endocrinology. 171:137-149.

Penning T. M., Y. Jin, S. Steckelbroeck, L. Rizner, and M. Lewis. 2004. Structurefunction of human $3 \alpha$-hyrdoxysteroid dehydrogenases: genes and proteins. Molecular and Cellular Endocrinology. 215:63-72. 
Pereira, M. N., E. F. Garrett, G. R. Oetzel, and L. E. Armentanto. 1999. Partial replacement of forage with nonforage fiber sources in lactating cow diets. I. Performance and Health. J. Dairy Sci. 82:2716-2730.

Pruitt, K. D., T. Tatusova, and D. R. Maglott. 2007. NCBI reference sequences (RefSeq): a curated non-redundant sequence database of genomes, transcripts and proteins. Nucleic Acids Res. 35:D61-D65.

Reinke, L. A. and M. J. Moyer. 1985. p-nitrophenol hydroxylation: A microsomal oxidation which is highly inducible by ethanol. Drug Metabolism and Disposition. 13:548:552.

Rhinehart, J. D., M. J. Starbuck-Clemmer, J. A. Flores, R. A. Milvae, J. Yao, D. H. Poole, and E. K. Inskeep. 2009. Low peripheral progesterone and late embryonic/early fetal loss in suckled beef and lactating dairy cows. Theriogenology. 71:480-490.

Robinson, N. A., K. E. Leslie and J. S. Walton. 1989. Effect of treatment with progesterone on pregnancy rate and plasma concentrations of progesterone in Holstein cows. J. Dairy Sci. 72:202-207.

Roche, J. F. 2006. The effect of nutritional management of the dairy cow on reproductive efficiency. Anim. Reprod. Sci. 96:282-296.

Sá Filho O. G., C. O. Lemley, M. E. Wilson, J. Hillegass, J. L. M. Vasconcelos, and W. R. Butler. 2009. Relationships between dry matter intake (DMI), plasma progesterone (P4), and liver catabolic enzymes in lactating dairy cows. Journal of Animal Science. 87(Suppt 2):M229. (Abstr.).

Saad, B., H. Thomas, H. Schawalder, F. Waechter, and P. Maier. 1994. Oxygen tension, insulin and glucagon affect the preservation and induction of cytochrome P450 isoforms in cultured rat hepatocytes. Toxicol. Appl. Pharm. 126:372-379.

Sahi J., E. L. Reyner, J. N. Bauman, K. Gueneva-Boucheva, J. E. Burleigh, and V. H. Thomas. 2002. The effect of bergamottin on diazepam plasma levels and P450 enzymes in beagle dogs. Drug Metabolism and Disposition. 30:135-140.

Sangsritavong, S., D. K. Combs, R. Sartori, L. E. Armentano, and M. C. Wiltbank. 2002. High feed intake increases liver blood flow and metabolism of progesterone and estradiol-17 $\beta$ in dairy cattle. J. Dairy Sci. 85:2831-2842.

Sarwar, M. J., J. L. Firkins, and M. L. Eastridge. 1992. Effects of varying forage and concentrate carbohydrates on nutrient digestibilities and milk production by dairy cows. J. Dairy Sci. 75:1533-1542. 
Savlik M., L. Polackova, B. Szotakova, J. Lamka, J. Velik, and L. Skalova. 2007. Activities of biotransformation enzymes in pheasant (Phasianus colchicus) and their modulation by in vivo administration of mebendazole and flubendazole. Research in Veterinary Science. 83:20-26.

Schams, D. and B. Berisha. 2004. Regulation of corpus luteum function in cattle-an overview. Reprod. Dom. Anim. 39:241-251.

Selvaraju, S., S. K. Agarwal, S. D. Karche, S. K. Srivastava, A. C. Majumdar, and U. Shanker. 2002. Fertility responses and hormonal profiles in repeat breeding cows treated with insulin. Anim. Reprod. Sci. 73:141-149.

Segura-Aguilar, J. E., V. Barreiro, and C. Lind. Dicoumarol-sensitive glucuronidation of benzo(a)pyrene metabolites in rat liver microsomes. Arch. Biochem. Biophys. 251:266-275.

Sheffel, C. E., B. R. Pratt, W. L. Ferrell, and E. K. Inskeep. 1982. Induced corpora lutea in the postpartum beef cow. II. Effects of treatment with progestogen and gonadotropins. J. Anim. Sci. 54:830-836.

Shimada H., K. Miura, and Y. Imamura. 2006. Characteristics and inhibition by flavonoids of $20 \alpha$-hydroxysteroid dehydrogenase activity in mouse tissues. Life Sciences. 78:2931-2936.

Shimojo, N., T. Ishizaki, S. Imaoka, Y. Junae, S. Fujii, and K. Okuda. 1993. Changes in amounts of cytochrome P450 isozymes and levels of catalytic activities in hepatic and renal microsomes of rats with streptozotocin-induced diabetes. Biochem. Pharmacol. 46:621-627.

Short, R. V. and J. G. Rowell. 1962. The half-life of progesterone in the peripheral blood of a ewe at two stages of gestation. Journal of Endocrinology. 25:369.

Sievert, S. J. and R. D. Shaver. 1993. Carbohydrates and Aspergillus oryzae effects on intake, digestion, and milk production by dairy cows. J. Dairy Sci. 76:245-254.

Smith, D. 1969. Removing and analyzing total nonstructural carbohydrates from plant tissue. Wisconsin Agric. Exp. Sta. Res. Rep. 41. p 1. Madison, WI.

Smith, D. L., B. M. Stinefelt, K. P. Blemings, and M. E. Wilson. 2006. Diet-induced alterations in progesterone clearance appear to be mediated by insulin signaling in hepatocytes. J. Anim. Sci. 84:1102-1109.

Sonstegard, T. S., A. V. Capuco, J. White, C. P. Van Tassell, E. E. Connor, J. Cho, R. Sultana, L. Shade, J. E. Wray, K. D. Wells, and J. Quackenbush. 2002. Analysis of bovine mammary gland EST and functional annotation of the Bos taurus gene index. Mamm. Genome. 13:373-379. 
Spotorno, V. G., A. Hidalgo, M. Barbich, A. Lorenti, and O. Zabal. 2006. Culture of bovine hepatocytes: a non-perfusion technique for cell isolation. Cytotechnology. 51:51-56.

Starbuck, M. J., R. A. Dailey, and E. K. Inskeep. 2004. Factors affecting retention of early pregnancy in dairy cattle. Anim. Reprod. Sci. 84:27-39.

Stevenson, J. S. and M. O. Mee. 1991. Pregnancy rates of Holstein cows after postinsemination treatment with a progesterone-releasing intravaginal device. J. Dairy Sci. 74:3849-3856.

Stevenson, J. S., M. A. Portaluppi, D. E. Tenhouse, A. Lloyd, D. R. Eborn, S. Kacuba, and J. M. DeJarnette. 2007. Interventions after artificial insemination: conception rates, pregnancy survival, and ovarian responses to gonadotropin-releasing hormone, human chorionic gonadotropin, and progesterone. J. Dairy Sci. 90:331340 .

Stocco, D. M. 2000. The role of the StAR protein in steroidogenesis: challenges for the future. J. Endocrinol. 164:319-325.

Stormshak, F., E. K. Inskeep, J. E. Lynn, A. L. Pope and L. E. Casida. 1963. Progesterone levels in corpora lutea and ovarian effluent blood of the ewe. Journal of Animal Science. 22:1021-1026.

Swanson, K. S., N. R. Merchen, J. W. Erdman, Jr, J. K. Drackley, F. Orias, G. N. Douglas, and J. C. Huhn. 2000. Technical note: a technique for multiple liver biopsies in neonatal calves. J. Anim. Sci. 78:2459-2463.

Szotakova, B., V. Baliharova, J. Lamka, E. Nazinova, V. Wsol, J. Velik, M. Machala, J. Neca, P. Soucek, S. Susova, and L. Skalova. 2004. Comparison of in vitro activities of biotransformation enzymes in pig cattle goat and sheep. Research in Veterinary Science. 76:43-51.

Tezuka N., M. Ali, K. Chwalisz and R. E. Garfield. 1995. Changes in transcripts encoding calcium channel subunits of rat myometrium during pregnancy. Am. J. Physiol. 269:1008-1017.

Thomford P. J. and P. J. Dziuk. 1986. The influence of dose of phenobarpital and interval to measurement on concentration of liver enzymes in barrows and gilts. J. Anim. Sci. 63:1184-1190.

Turino, L. N., R. N. Mariano, M. I. Cabrera, D. E. Scandolo, M. G. Maciel, and R. J. A. Grau. 2010. Pharmocokinetics of progesterone in lactating dairy cows: Gaining some insights into the metabolism from kinetic modeling. Journal of Dairy Science. 93:988-999. 
Van Knegsel, A. T. M., H. van den Brand, J. Dijkstra, S. Tamminga, and B. Kemp. 2005. Effect of dietary energy source on energy balance, production, metabolic disorders and reproduction in lactating dairy cattle. Reprod. Nutr. Dev. 45:665688.

Van Knegsel, A. T. M., H. van den Brand, J. Dijkstra, S. Tamminga, and B. Kemp. 2007. Effect of glucogenic vs. lipogenic diets on energy balance, blood metabolites, and reproduction in primiparous and multiparous dairy cows in early lactation. J. Dairy Sci. 90:3397-3409.

Van Zijl, F. and W. Mikulits. 2010. Hepatospheres: Three dimensional cell cultures resemble physiological conditions of the liver. World J. Hepatol. 27:1-7.

Villarroel, A., A. Martino, R. H. BonDurant, F. Deletang and W. M. Sischo. 2004. Effect of post-insemination supplementation with PRID on pregnancy in repeat-breeder Holstein cows. Theriogenology. 61:1513-1520.

Volak, L. P., S. Ghirmai, J. R. Cashman, and M. H. Court. 2008. Curcuminoids inhibit multible human cytochromes P450 (CYP), UDP-glucuronosyltransferase (UGT), and sulfotransferase (SULT) enzymes, while piperine is a relatively selective CYP3A4 inhibitor. Drug Metab. Dispos. 36:1594-1605.

Waxman, D. J., D. P. Lapenson, T. Aoyama, H. V. Gelboin, F. J. Gonzalez, and K. Korzekwa. 1991. Steroid hormone hydroxylase specificites of eleven cDNAexpressed human cytochrome P450s. Archives of Biochemistry and Biophysics. 290:160-166.

Weems, C. W., Y. S. Weems, C. N. Lee and D. L. Vincent. 1989. Progesterone in uterine and arterial tissue and in jugular and uterine venous plasma of sheep. Biology of Reproduction. 40:1-6.

Yee, D. J., V. Balsanek, D. R. Bauman, T. M. Penning, and D. Sames. 2006. Fluorogenic metabolic probes for direct activity readout of redox enzymes: Selective measurement of human AKR1C2 in living cells. Proceedings of the National Academy of Sciences. 103:13304-13309.

You, L., 2004. Steroid hormone biotransformation and xenobiotic induction of hepatic steroid metabolizing enzymes. Chem-Biol. Interact. 147:233-246.

Zangar, R. C. and R. F. Novak. 1998. Posttranslational elevation of cytochrome P450 3A levels and activity by dimethyl sulfoxide. Arch. Biochem. Biophy. 353:1-9.

Zerilli, A., D. Ratanasavanh, D. Lucas, T. Goasduff, Y. Dreano, C. Menard, D. Picart, and F. Berthou. 1997. Both cytochromes P4502E1 and 3A are involved in the O- 
hydroxyltaion of p-nitrophenol, a catalytic activity known to be specific for P4502E1. Chem. Res. Toxicol. 10:1205-1212.

John $\mathrm{H}$. Hagen 